\title{
PROCES HRVATSKE NACIONALNE INTEGRACIJE U MOSTARU
}

Tihomir ZOVKO

Fakultet prirodoslovno-matematičkih i

odgojnih znanosti

Matice hrvatske b.b.

$\mathrm{BiH}$ - 88000 Mostar

E-pošta: tihomir.zovko@hotmail.com
UDK 930.85(497.6 Mostar)"18" 061.2(497.6 Mostar=163.42)"18"

Izvorni znanstveni rad Primljeno: 17. ožujka 2016.

Prihvaćeno: 8. lipnja 2016.

\section{Sažetak}

Mostar je u XIX. stoljeću bio vodeći grad u Bosni i Hercegovini u procesu hrvatske nacionalne integracije. Tema ovoga rada je uključivanje različitih društvenih struktura u proces integracije i stvaranja hrvatske nacije, te osnivanje institucija preko kojih se ova aktivnost odvijala. U XIX. stoljeću čitaonice i društva imale su veliku važnost te preko njih ide proces integracije jer politička djelatnost nije bila dopuštena do početka XX. stoljeća. Tijekom završne faze nacionalne integracije više je pažnje posvećeno prosvjeti i gospodarstvu.

Ključne riječi: Mostar, nacionalna agitacija, Bratovština sv. Antuna Padovanskog, tiskara, novine, Osvit, HGPD Hrvoje, udruge. 


\section{Uvod}

U drugoj polovici XIX. stoljeća hrvatske zemlje zahvaćene su preporodnim gibanjem koje dovodi do procesa integracije hrvatske nacije. Proces hrvatske nacionalne integracije nije obuhvatio sve hrvatske zemlje u isto vrijeme, zbog različita povijesnog razvitka, nego se javlja u uzastopnome slijedu. On se širi iz Dalmacije, Slavonije i Hrvatske u Hercegovinu i Bosnu koja je pod osmanskom vlašću. Neravnomjeran tijek i stagnacija pri integraciji hrvatske nacije rezultat je dezintegracijskih čimbenika od XV. do XIX. stoljeća. Stvoreno je više zasebnih političko-teritorijalnih jedinica sa slabom međusobnom komunikacijom i različitim društvenim strukturama: Hrvatska i Slavonija imaju europski agrarno-staleški feudalni sustav, Vojna krajina ima obilježje seljačkoga društva, Dalmacija je predstavljena kao društveno-mediteransko područje u kojemu su jedinice grad i okolica, u Istri je mediteranski feudalni oblik društva, dok je u Bosanskom pašaluku sustav osmanlijskoga feudalizma. Zbog nerazvijenosti robno-novčanoga gospodarstva nije bilo većih dodira pučana susjednih područja, pa često ni između pojedinih lokalnih zajednica iste teritorijalno-političke jedinice. Nerazvijenost gradova i nepostojanje ozbiljnije trgovine također je dezintegrativni čimbenik u procesu integracije hrvatske nacije kao i mali broj katolika u postojećim urbanim sredinama. Što se tiče Mostara, ograničavajućih faktora bilo je nekoliko: nepostojanje sakralnih objekata kako u ovom gradu tako i u cijeloj Hercegovini sve do sredine XIX. stoljeća, nesklonost strane vladajuće elite, prometna izoliranost i otežana međusobna komunikacija, niska razina obrazovanosti i velik broj nepismenoga stanovništva te pomiješanost s druge dvije konfesije koje su bile u boljem položaju, jer su imale više urbanoga stanovništva.

Među integracijskim činiteljima je plemićka tradicija koja čuva uspomenu na samostalnu hrvatsku državu u ranome srednjem vijeku te pojava renesansne književnosti i umjetnosti u Dubrovačkoj Republici i Dalmaciji. Integrirajući činitelji su svijest o hrvatskoj narodnoj državi, katolička vjera, jezik i franjevci, rodom iz ovih krajeva, koji dobro poznaju mentalitet naroda. Česta uporaba hrvatskoga imena, potpuno približavanje triju hrvatskih narječja, svakodnevni život puka, običaji, kultura, tradicija i svijest o zajedničkome podrijetlu, integracijski su činitelji koji utječu na početak procesa integracije hrvatske nacije. Hrvatski se narod u Bosni i Hercegovini razvio iz hrvatskih plemena i rodova koji su naseljavali prostore zapadne, jugozapadne i središnje Bosne, odnosno prostore između rijeka Une, Save i donjega toka Drine, a na drugoj strani Neretve (zapadnu, južnu i sjevernu Hercegovinu). ${ }^{1}$

1 "Bosna i Hercegovina", u: Enciklopedija Jugoslavije, JLZ, Zagreb, 1983., str. 141. 
Hrvatska se etnička zajednica oblikovala u poseban narod, u feudalnome smislu riječi, pod utjecajem katoličanstva, vezanosti uz Hercegovinu kao domovinu, te posebnoga položaja u sustavu osmanske vladavine. Hrvatski narod, unatoč pritiscima i egzodusima, uspio je egzistencijalno, duhovno, kulturno i narodnosno očuvati se i pripremiti se za punu nacionalnu emancipaciju i integraciju tijekom XIX. stoljeća. Pod pojmom proces nacionalne integracije nije shvaćeno preporađanje ili budenje već postojeće, ali usnule nacije, nego razdoblje u kojem čitavo društvo još nije obuhvaćeno nacionalnom ideologijom i u kojoj se u procesu nacionalne integracije uključuje uska jezgra sastavljena od pripadnika viših društvenih slojeva. Proces hrvatske nacionalne integracije nije obuhvatio istodobno sve hrvatske zemlje zbog njihova različitoga povijesnog razvitka. On se u pojedinim pokrajinama javlja u uzastopnome slijedu. Pod pojmom integracija hrvatske nacije podrazumijevamo složeni proces preobrazbe tradicionalne hrvatske etničke zajednice, odnosno srednjovjekovnoga hrvatskog naroda u modernu naciju XIX. i XX. stoljeća. U periodizaciji hrvatskoga narodnog preporoda u hrvatskim zemljama primjenjuje se model koji je razradio praški profesor Miroslav Hroch. ${ }^{2}$ Proces hrvatske nacionalne integracije na području Bosne i Hercegovine ima tri razdoblja u svome razvoju:

I. Razdoblje znanstvene nacionalne propagande,

II. Razdoblje nacionalne agitacije,

III. Razdoblje masovnoga nacionalnog pokreta.

2 Miroslav Hroch, "Oblikovanje modernih nacija i nacionalni pokret 19. stoljeća", u: Časopis za suvremenu povijest, I., Zagreb, 1979., str. 23-40.

Taj model ima tri faze: "A" mala jezgra rodoljuba širi narodnu svijest na kulturnom području, "B" inteligencija širi nacionalnu svijest i političkim metodama može obuhvatiti pojedine društvene slojeve, "C" nacionalna integracija postigla je visok stupanj i razvila širi nacionalni pokret. Vidi: Mirjana Gross, Historijska znanost, Zagreb, 1980., str. 306; Miroslav Hroch, Društveni preduvjeti nacionalnih preporoda u Europi: komparativna analiza društvenog sustava patriotskih grupa malih europskih nacija, Srednja Europa, Zagreb, 2006., str. 29-56; Umjesto faza A, B i C sada su razdoblja. Tipovi koje Hroch navodi ne mogu se primijeniti kod procesa hrvatske nacionalne integracije, jer se on odvija u specifičnim uvjetima prožet s druga dva nacionalna pokreta na istom prostoru. Nedostatak urbanoga stanovništva kod Hrvata u Hercegovini utjecao je i na brzinu procesa nacionalne integracije kao i nepovoljna društvena struktura u kojoj je dominantno seljaštvo. Sve su to bili dezintegrirajući čimbenici u procesu hrvatske nacionalne integracije. Tijekom četiri desetljeća nazočnosti Monarhije ovi parametri se mijenjaju te hrvatsko stanovništvo doživljava urbane i strukturalne promjene koje su integracijski čimbenici u stvaranju hrvatske nacije u Hercegovini. 
Katolici su u sklopu Osmanskoga Carstva bili brojčano najmanja kategorija pučanstva. I kao takvi su omalovažavani i zapostavljani. Sve ove navedene okolnosti imale su utjecaja na različit razvoj procesa nacionalne integracije Hrvata u Bosni i Hercegovini. Proces hrvatske nacionalne integracije u Mostaru, zbog svoga zemljopisnog položaja i blizine Dalmacije, upućenosti na trgovačke, kulturne, vjerske i političke sveze te demografsko okruženje, nalazi se na rubu najhomogenijega hrvatskog nacionalnog prostora. ${ }^{3}$ Mostar je vodeće središte procesa hrvatske nacionalne integracije u Bosni i Hercegovini do početka XX. stoljeća, kada vodeću ulogu preuzima Sarajevo i građanska inteligencija. Zbog toga što se radi o gradu, vodećem u razvoju hrvatske nacionalne integracije, periodizacija hrvatskoga narodnog preporoda u Mostaru razlikuje se od periodizacije u Bosni i Hercegovini. U hrvatskoj historiografiji klasifikaciju hrvatskoga narodnog preporoda dala je Mirjana Gross. ${ }^{4}$

Faza $A$ traje od 1835. do kraja 80-ih godina, faza $B$ od 1890 -ih do pred rat i faza $C$ u Jugoslaviji. ${ }^{5}$ Ovu klasifikaciju ne možemo primijeniti za Mostar, a ni za Hercegovinu, jer je proces nacionalne integracije imao smjer širenja od juga prema sjeveru iz Mostara kao glavnoga hrvatskog narodnog središta prema Bosni. Hrvatski narodni preporod u Mostaru ima dva razdoblja u procesu integracije hrvatske nacije. Moramo upozoriti da se hrvatski narod u Mostaru, kao i u Hercegovini i Bosni, u razdoblju znanstvene nacionalne propagande i djelomično razdoblja nacionalne agitacije nalazio u sklopu Osmanskoga Carstva, a nakon toga kroz razdoblje nacionalne agitacije i razdoblje masovnoga nacionalnog pokreta u sastavu Austro-Ugarske Monarhije. Proces nacionalne integracije u Mostaru je isprepleten s druga dva nacionalna pokreta, a zbog različitih pogleda na budućnost ovoga prostora dolazi do čestih sučeljavanja i sukoba. Upravo su u tom gradu sučeljena tri nacionalna pokreta koji djeluju na istom prostoru.

U Mostaru možemo pratiti razdoblje nacionalne agitacije i masovni nacionalni pokret, a prvo razdoblje znanstvene nacionalne propagande odvijalo se izvan grada u bosanskim franjevačkim samostanima.

3 Grad Mostar nema većinu Hrvata tijekom XIX. stoljeća, ali kotar Mostar ima većinu (katolici su većina u sva četiri popisa stanovništva 1879., 1885., 1895. i 1910.; opširnije ovdje u drugome poglavlju).

4 Mirjana Gross, "O integraciji hrvatske nacije", u: Društveni razvoj u Hrvatskoj od XVI. do početka XX. stoljeća, SNL, Zagreb, 1981., str. 175-191.

5 Isto, str. 188. 


\section{RAZDOBLJE HRVATSKE NACIONALNE AGITACIJE U MOSTARU}

\subsection{Mostar u XIX. stoljeću}

Mostar je od XV. stoljeća, zahvaljujući svome položaju na obalama Neretve, imao posebno mjesto i ulogu u okvirima Osmanskoga Carstva. Neretva je razdvajala Istok i Zapad, a sam grad je bio jedan od smjerova za daljnje nadiranje prema Zapadu do kraja XVII. stoljeća. Prelaskom iz osvajačke u obrambenu fazu grad postaje još značajniji zahvaljujući svome zemljopisnom položaju. Zahvaljujući interesiranju velikih sila za prilike i položaj kršćana u okviru Osmanskoga Carstva, česti su i putnici iz europskih zemalja koji opisuju Hercegovinu, a osobito njezino središte Mostar. Zbog blizine Dalmacije i prirodne komunikacije dolinom Neretve Mostar je bio na pogodnom mjestu za trgovinu, jer preko njega su vodili putovi iz Bosne prema Dalmaciji. Da je gospodarski Hercegovina, kao i Mostar, upućena na Dalmaciju i na zapadne zemlje, govori nam podatak o trgovini medom. "Med iz Hercegovine se izvozio u Austriju i Italiju. Posrednici u trgovini su bili mostarski trgovci koji su održavali tijesne veze s tršćanskim trgovcima. Izvozili su sirovine, a uvozili kolonijalnu robu. Oni su snabdijevali i osmansku vojsku. Skladišta su imali u Splitu, Makarskoj, Metkoviću, Kleku i Carini kod Trebinja. Kiridžije su bili seljaci sa svojim konjima i mazgama. Isplata kirije je bila u novcu."6

Dolaskom prve austrijske uprave (1797.-1805.) u Dalmaciju Splićanin Frane Zavoreo izradio je projekt cestovne mreže u Dalmaciji. Jedan od cestovnih smjerova bio je Knin - Vrlika - Sinj - Vrgorac - Neretva. Dalmatinsko gospodarstvo trebalo je jače zaleđe, na koje se stoljećima prirodno oslanja Dalmacija, tako da je pitanje uspostave željeznice s hercegovačko-bosanskim zaleđem jedno od glavnih gospodarskih pitanja. ${ }^{7}$ Međutim, zbog političkih okolnosti, u kojima se nalaze hrvatske zemlje, ova se ideja nije mogla lako realizirati. Nakon izgradnje ceste, koja je povezala Mostar i Metković još za vrijeme Osmanskoga Carstva, Mostar je dobio trgovačku važnost i komunikacija dolinom Neretve postaje najznačajniji trgovački pravac. ${ }^{8}$ Željezničku vezu Dalmacije i Hercego-

6 Marko Vego, Bekija kroz vijekove, Sarajevo, 1964., str. 186.

7 Igor Karaman, Privreda i društvo Hrvatske u 19. stoljeću, Školska knjiga, Zagreb, 1972., str. 266-267.

8 Ivan Jurić, Gospodarski razvoj luke i trgovišta Metković 1850.-1918., Matica hrvatska, Metković, 2000., str. 62-66. 
vine uspostavlja Austro-Ugarska Monarhija tek nakon okupacije Bosne i Hercegovine 1885. godine. ${ }^{9}$ Prirodna komunikacija bila je dolinom rijeke Neretve koja je poveznica Hercegovine i Dalmacije. Tek je AustroUgarska Monarhija započela s regulacijom rijeke Neretve i održavanjem plovnoga kanala. Problem je bila velika količina erozivnoga materijala što ga Neretva donosi u svome koritu. ${ }^{10}$

U Mostaru tijekom prve polovice XIX. stoljeća možemo pratiti sukobe lokalnih moćnika Ali age-Voljavice i Ali-age Dadića koji je završio razaranjem i pljačkom imovine zulmćara Ali-age Voljavice. ${ }^{11}$ Ratni sukobi s Crnogorcima i Rusima tijekom 1806. godine imali su odjeka u Mostaru. Nakon ustanka Srba u Šumadiji brojni muslimani odlaze u borbu, a troškove poslije poraza moraju platiti katolici u Hercegovini. U sukobu s centralnom vlasti katolici u Hercegovini moraju izabrati stranu, a ako su na poraženoj strani, plaćaju veliku cijenu. Najznačajnija ličnost u Hercegovini bio je Ali-paša Rizvanbegović koji je zemlju gospodarski unaprijedio i vladao dva desetljeća autokratski. Zbog svojih interesa dopustio je da franjevci ponovo mogu popravljati svoje sakralne objekte te na taj način otvorio jedno novo poglavlje u povijesti katolika. Njegova strahovlada obilježena je gospodarskim prosperitetom, ali i rigidnim osmanlijskim odnosom prema nemuslimanima. Pred kraj njegove vladavine u Mostaru je ostalo samo 12 katoličkih obitelji.

Dolaskom franjevaca u Mostar i izgradnjom rezidencije u Vukodolu, ${ }^{12}$ koja je započeta 7. svibnja 1847. a useljena 1849. godine, mijenja se udjel katolika u životu Mostara.

"Modelirana je na način modernih građevina arhitekture i talijanskog ukusa sadrži 13 vrlo komfornih soba s podrumom i kuhinjom - do-

9 "Na svečanost otvorenja željeznice Mostar-Metković", u: Novi Hercegovački bosiljak, br. 24, Mostar, 13. lipnja 1885. "Dan 13. lipnja 1885. bit će zlatnimi slovi zabilježen u sveobćoj poviesti; dan, u koji je naša previsoka vlada za dobrobit svojih viernih podanika, nakon sedam godina svojeg vladanja sretno uzdigla željezničku prugu Mostar-Metković." (Kod svih novina koje su izlazile u Mostaru: Bosiljak, Novi Hercegovački bosiljak, Glas Hercegovca i Osvit u periodu 1883.-1908. nema uvijek oznaka stranice, op. T. Z.)

10 I. JURIĆ, Gospodarski razvoj luke i trgovišta Metković..., str. 106-119.

11 Arhiv franjevačKoga samostana Svetoga Duha u Fojnici, O hercegovačkoj buni 1802.-1813., zabilježio fra Marko Kalamut, IX/120; Milenko M. VukičEvić, Znameniti Srbi Muslimani, Srpska književna zadruga, Beograd, 1906. Autor je doslovce prepisao kroniku fra Marka Kalamuta i dodao srpsko porijeklo Dadića o čemu u spomenutoj kronici nema spomena.

12 Ante Marić, "Biskupska kuća u Vukodolu", u: Hum, sv. 1, Mostar, 2006., str. 245-259. 
sta prostranima. Ima jednu kapelu, koja nije ništa manja od one na Šir. Brijegu... Prostrani samostan na Š. B. i ne mala biskupska rezidencija u Mostaru očevidni su plodovi velikodušnog milosrđa i građevine istovremeno su svjedočanstvo čitavom svijetu iskrsle vječne zahvalnosti onima koji su na svojim milostinjama dali doprinos tako značajnom spomeniku i svaki čas pokazuje na izvanredno čudo Gospodinovo."13

Nakon dolaska franjevaca i izgradnje rezidencije u Vukodolu Mostar je postao središte borbe za opstojnost Hrvata na ovim prostorima. Tijekom druge polovice XIX. stoljeća izrastao je u prosvjetno, kulturno, gospodarsko, vjersko i političko središte Hrvata u Bosni i Hercegovini. O izgledu grada u ovome razdoblju govore podatci koje donose različiti autori u svojim djelima nastalim tijekom XIX. stoljeća. Tako fra Petar Bakula opisuje: "Grad Mostar je kao u ždrijelu planine Velež i velikog brda Hum. Velež s istoka, a Hum sa zapada ostavlja uz Neretvu s obje strane nisku ravnicu, nabijenu kućama građana. Od jugoistoka između brda i rijeke sve do mosta veoma je velika tjesnoća. Nije tako sa sjeverne strane, okrenute prema zapadu, gdje se i Velež i Hum savijaju i daju mjesta većoj ravnici Bijelom polju i Crničkom polju. Stoga grad Mostar sa zapada i djelomično sa sjevera ima otvoren i lijep pogled, a najljepši mu je dio Carina."14 $\mathrm{O}$ samom izgledu grada navodi Bakula: "U pogledu čistoće ulica grada, u zadnje dvije godine počelo se dosta uređivati. Kuće u gradu, kako su većinom stare turske izrade, vrlo su tvrde, ali manje pravilima umjetnosti... Ovih posljednjih godina osim kršćana i neki manje fanatični Turci počeli su graditi kuće elegantnijih dimenzija. Danas se može vidjeti više kuća lijepoga stila sličnih vojnom logoru. Među kršćanskim građevinama odskaču rezidencija katoličkog biskupa, te katoličke i pravoslavne škole... Imamo jednoga liječnika, hotel nijedan, manje udobnih svratišta. Imamo preko tri stotine trgovina... Moćniji trgovci u gradu su pravoslavni, onda Turci, katolici su u veoma malom broju i to kao novajlije u poslu." ${ }^{15}$ Cesare Durando, talijanski konzul u Sarajevu, napisao je 1868. godine "Trgovinsko-ekonomski

13 Petar Bakula, "Kratak sveto-povijesni prikaz o osnutku redovničko-misijske Kustodije i Apostolskog vikarijata u Hercegovini", u: AndRIJA Nikić, Franjevačka knjižnica u Mostaru, Mostar, 1981., str. 60-61.

14 Petar Bakula, Hercegovina prije sto godina ili šematizam fra Petra Bakule, Mostar, 1970., str. 97. Opis Mostara iz 1857. godine donosi u svome djelu AlEKsanDar Giljferding, Putovanje po Hercegovini, Bosni i Staroj Srbiji, IRO Veselin Masleša, Sarajevo, 1972., str. 20-51.

15 P. BAKUla, Hercegovina prije sto godina..., str. 98-99. 
osvrt na Hercegovinu". ${ }^{16}$ Ovo pokazuje da su velike sile nastojale, za svoje interese, što bolje upoznati ove egzotične prostore Osmanskoga Carstva. Cesare Durando navodi da: "...u Hercegovini nema zapravo nego dva grada. Mostar i Foča. Sva ostala mjesta su sela, varošice, zaseoci, razasuti po grupicama po manje strmim i pristupačnim obroncima brda ili rasijani po dolinama". ${ }^{17}$

O izgledu Mostara Durando navodi: "Kuće su zidane i pokrivene kamenim pločama, radi kojih je krov preko mjere težak. Površina ima malo metara i sastoji se općenito od četiri sobice, dvije u prizemlju, a dvije iznad njih s visokim plafonom, malim prozorčićima i drvenim podom. Neke imaju ispred, a neke iza kuće vrt sa stablima smokava i dudova... Osim jednog puta, koji ide dužinom uz lijevu obalu Neretve, svi su drugi samo puteljci nepristupačni za kola." ${ }^{18}$ Iz Dubrovnika Kristofor Milas, svećenik Dubrovačke biskupije, dolazi u Mostar da se zaredi za svećenika 1872. godine kod apostolskoga vikara fra Anđela Kraljevića. Tom je prigodom opisao put od Dubrovnika do Mostara kao i grad Mostar: "Osim malo kuća, koje su novosagrađene poput kuća u našim gradovima, stanovi su iztočnjački sagrađeni samo na jedan boj sa malo prozora i to s perzijankama (griljama)... Što se tiče trgova i ulica mostarskih, po njima je hodati da Bog sačuva, jer su nepopločane i zapuštene sasvim, te ljeti od velike prašine, a zimi od velika blata ne može čovjek ugodno po njima da ide..."19

U Hercegovini 1875. godine boravi A. J. Evans, koji opisuje grad: "Mostar je kao grad ostavio na nas prijatniji utisak od ma kojeg bosanskog grada. Kuće nisu izgrađene od običnog drveta i blata, već su podignute od kamena... Mostarske ulice neprekidno ostavljaju na nas utisak da smo došli do granice rimske civilizacije. Ove iz kamena podignute kuće nisu više turski Chalet, već pre talijanska ili dalmatinska Casa... Mostar ima oko osamnaest hiljada stanovnika. Značajan je to grad u ovom kraju. Dugo je bio glavnim i trgovačkim skladištem Hercegovine i davno je bio poznat po proizvodnji mačeva kao što su oni iz Damaska...

Napustili smo Mostar defilirajući preko starog mosta na Neretvi i satima nastavili kaskanje dosadnom i zaprašenom ravnicom, ostavljajući na desno ruševine Blagaja, nekadašnjeg feudalnog uporišta. Na sunčanom

16 Cesare Durando, "Trgovinsko-ekonomski osvrt na Hercegovinu", u: Andrija Nikić, Franjevačka knjižnica u Mostaru, str. 71-90.

17 Isto, str. 72.

18 Isto.

19 "Iz Metkovića u Mostar 1872. godine", u: Osvit, br. 25, Mostar, 25. 3. 1899., str. 1-2. 
zalasku čuli smo šapat molitve. Jašući pored nas, raja je neprekidno ponavljala Ave Marija."20

Zbog važnoga, prometnoga i strateškoga položaja Mostar je privlačio brojne strance, ali i domaće ljude, koji prolaze kroz Bosnu i Hercegovinu. Jedan od karavanskih putova iz Dalmacije prema Bosni vodio je dolinom Neretve preko Mostara, Konjica, Ivan planine do Sarajeva. O cestama u svome putopisu Charles Yriart kaže: "U cijeloj pokrajini postoje samo tri zadovoljavajuće ceste. Prva ide od Dalmatinske granice do Sarajeva. Ona prolazi od Metkovića iznad Kleka, prati lijevu obalu Neretve i prolazi kroz Mostar. Druga ide iz Mostara prema Trebinju i prolazi kroz Stolac i Ljubinje. Treća, u veoma lošem stanju, ide od Trebinja do Kleka i račva se prema Dubrovniku. Izvan ovih putova, jedine saobraćajnice su staze koje su prohodne za brdske konje i mazge, i bilo bi potpuno nemoguće da se tuda provedu ikakvi drugi transporti osim karavanski."21

C. Yriart o cesti između Kleka i Mostara navodi: "Jedini pristupačan put koji povezuje Klek s glavnim gradom Hercegovine Mostarom nalazi se do iza Metkovića na austrijskoj teritoriji, a jedini postojeći prilaz na turskoj teritoriji sastoji se, počev od Neuma, od strme staze koja vodi do doline Trebišnjice. Taj jedini put nije ništa drugo do nesiguran tjesnac, opasan i u normalno vrijeme; tako da, uviđajući gotovo nepremostive poteškoće s kojima se susreću Turci kad hoće da snabdiju svoje trupe u tim siromašnim, danas opustošenim krajevima..."22

Yriart opisuje i put kojim su konzuli velikih sila za vrijeme hercegovačko-bosanskoga ustanka 1875. godine išli iz Mostara prema južnoj Hercegovini: "Konzuli, koji su krenuli iz Mostara 12. septembra, išli su usporedo u dva pravca i sišli u donju Hercegovinu da bi se sreli sa ustanicima i sa njima razgovarali; predstavnici Austrije, Italije i Njemačke pratili su dalmatinsku granicu; predstavnici Francuske, Rusije i Engleske došli su preko Stoca, Fatnice i Bileće."23

U komunikacijama Hercegovina je bila odsječena od mora zbog političkih razloga, a unutar Hercegovine nije bilo značajnijih kolskih prometnica. Prvi kolski put gradi se 1863. od Mostara, Bijelog Polja, Salakovca,

20 Arthur John Evans, Kroz Bosnu i Hercegovinu u vrijeme pobune 1875., IRO Veselin Masleša, Sarajevo, 1981., str. 137.

21 Charles Yriarte (ŠArl IrlJart), Bosna i Hercegovina putopis iz vremena ustanka 1875.-1876., IRO Veselin Masleša, Sarajevo, 1981., str. 137.

22 Isto, str. 134-135.

23 Isto, str. 153-154. 
Jablanice do Konjica. ${ }^{24}$ Ovaj put prisilno rade kršćani i to će kasnije biti jedan od razloga za ustanak 1875. godine. Jedan put je vodio od Mostara, Bišća, Gubavice, Dubrava (s ogrankom prema Stocu) do Gabele i spajao se s austrijskim putom u Metkoviću. Postojala je i komunikacija iz Mostara preko Bišća prema Nevesinju. ${ }^{25}$ Bilo je i javnih putova koji nisu bili kolski: Mostar - Bišće - Jasenica - Čitluk do Ljubuškoga i Mostar - Ilići - Žovnica do Blata. ${ }^{26}$

Nakon okupacije 1878. godine uspostavljaju se gospodarske veze Hercegovine i Dalmacije. Roba iz Hercegovine dolazi u luku Gruž, a osobito će biti pojačan promet robe nakon povezivanja Mostara, željezničkom prugom, s Metkovićem i Gružem. Dolaskom Austro-Ugarske Monarhije započela je gospodarska obnova Hercegovine kao i njezino uključivanje u prometni sustav države. Nakon 1878. godine Mostar je postao još prometnije mjesto. Tada je sagrađeno jedanaest novih hanova i to: Bošnjića, Baltin, Pavića, Ćirića, Pičetin, Kahvin, Kudinov, Arpadžića, Komadov, Srpsko-pravoslavne općine i Berberčev han. Godine 1893. otvorena je novoizgrađena cesta Gruda - Mrcine - Grab i na taj način je povezana južna Dalmacija s Hercegovinom. ${ }^{27}$

Mostar dolaskom Austro-Ugarske Monarhije postaje sve značajnije trgovačko središte. Osvit donosi članak "Mostar prije i sada": "...Mostar zgodan za prevoz robe iz Mletaka, Trsta i Carigrada, te Dubrovnika, koji je bio također poznata skela na moru. A i bivalo je tada trgovaca putnika. Nagrnu preko Metkovića, Trebinja, ili Imotskoga, kao što i iz Sarajeva, nesnosnim putovima i putićima." ${ }^{28}$ Početkom XX. stoljeća Stjepan Šadl-Srijemac zajedno s đacima putuje kroz Bosnu i Hercegovinu i o Mostaru kaže: "...što sve ima u Mostaru, ne treba ni spominjati valja samo pomisliti da je to glavni grad, koji može usporedo stajati uz ma koji europski grad iste veličine." ${ }^{29}$ Posebno ističe mostarske vinograde koji su za primjer kako treba obrađivati i njegovati lozu. "Vinograd čist nema ni travčice ni za lijek, svaki čokot svoj - kolac - ima, a svaka vrsta loze tablicama je označena." ${ }^{10}$

24 P. BAKUla, Hercegovina prije sto godina..., str. 23.

25 Isto.

26 Isto.

27 "Ljetopis za godinu 1893.", u: Školski vjesnik, Sarajevo, 1894., str. 45.

28 "Nova cesta", u: Osvit, br. 9, Mostar, 24. 8. 1898.

29 StJePAn ŠAdL, "Đački izlet kroz Bosnu, Dalmaciju i Hercegovinu za jedanaest dana", u: Školski vjesnik, VIII., Sarajevo, 1901., str. 460.

30 Isto, str. 459. 
Stjepan Šadl uspoređuje mostarske vinograde s onima u Dalmaciji: "Isto bi to i za Dalmaciju vrijedilo. Jer kad bi se po čitavoj Dalmaciji vinogradi ovako obrađivali kao u ovim krajevima kroz koje smo mi prošli, onda bi s pravom mogao reći, da ni trećina a možda ni manje ovog vina, što se po čitavom svijetu pod dalmatinskim imenom razašilje, nije dalmatinsko, nego Bog zna, u kakvom je vinogradu raslo? Jer nije moguće, da ona mala Dalmacija - makar i s otocima - po onakvom obrađivanju gotovo čitav svijet pravim vinom opskrbljuje." ${ }^{31}$

Koliko su veze Hercegovine i Dalmacije bile razvijene i kako se reflektira stanje iz jedne u drugu, vidi se nakon uvođenja vinske klauzule 1892. godine. ${ }^{32}$ Osvit u broju 66. od 25. kolovoza 1900. na petoj stranici donosi "Posljedice vinske klauzule u Hercegovini". Nakon uvođenja vinske klauzule opada prodaja stoke iz Hercegovine u susjednoj Dalmaciji. Posljedica ovoga je pad cijena stoke u Hercegovini, te znatno smanjen izvoz. Tako je izvoz marve za 1899. godinu u Hrvatsku, Slavoniju i Dalmaciju manji za 24,85 \% (80.633 komada), a, istodobno, uvoz konja se povećao zbog izgradnje željeznice u Hercegovini. ${ }^{33}$ I u narednim brojevima Osvit donosi tekstove koji govore o posljedicama vinske klauzule: "Nesretni ugovor što je carevina sklopila sa Italijom on je oteo kruh vinogradarima u Dalmaciji i Istri... Naši vinogradari zbog toga propadaju i traže da se taj ugovor više ne obnovi." ${ }^{34}$ Ovi zorni primjeri govore o povezanosti Hercegovine i Dalmacije koje su prirodno orijentirane jedan na drugu.

Duga granična linija između Hercegovine i Dalmacije nije mogla biti preprekom za komunikacije pučana iz dvije susjedne državne tvorevine toga doba. Nepostojanje prometnica, osim karavanskih i akutna opasnost od raznih bolesti, posebice kuge koja se često širila među pučanstvom, ometali su razvoj značajnijih gospodarskih veza ova dva prostora. ${ }^{35}$

31 Isto.

32 Rudo Kraljević, Vinsko-vinogradarska privreda i demografski rasap Južne Hrvatske, Književni krug Split, Split, 1994., str. 199-204.

33 "Import i export marve u godini 1899.", u: Osvit, br. 70, Mostar, 8. 9. 1900., str. 6-7.

34 "Glas o ljetini i školi iz naroda", u: Osvit, br. 67, Mostar, 29. 8. 1900. i br. 78, 19. 12. 1900., str. 4. "...Treba zabraniti uvoz talijanskog vina, naši vinogradari stradaju zbog filoksere. Cijena grožđa ove godine 6-10 nč. tim neće moći ni modri kamen platiti."

35 DržAvni ARhiv u ZAdru, Tajni spisi Namjesništva 1832., busta II., sv. 11, br. 185, Splitska općina upozorava na širenje kuge iz pograničnih krajeva Bosne i Hercegovine. 
Dalmatinske luke nisu se mogle brže razvijati bez oslonca na prirodno zaleđe. "...Dalmatinske luke su mrtve. One nemaju suvremenih saobraćajnih veza s neposrednim i daljnjim zaleđem..." ${ }^{36}$ Splitska luka je imala najveći promet robe iz Bosne i Hercegovine koja je išla dalje na zapad, ali i robe koja se uvozi na prostor Osmanskoga Carstva. ${ }^{37}$

Splitska općina još 1832. godine traži dozvolu za dolazak osmanskih karavana jer to ujedno pomaže i razvitku dalmatinske trgovačke mornarice. ${ }^{38}$ Zbog lošega stanja prometnica ova veza je sputavana i nije se moglo govoriti o nekom većem prometu ljudi i robe. Veze Dalmacije s Hercegovinom bile su iz Metkovića i Vrgorca. "Prema sjeveru vodi cesta iz Splita preko Sinja na Bili Brig, građena je još u doba francuske uprave i također veoma slaba tako da putovanje do Mostara traje tri dana, a do Sarajeva čak šest dana." ${ }^{39}$ Grga Novak navodi da prosječno dnevno u splitski lazaret od 1855. do 1860. godine stiže 50-60 konja. ${ }^{40}$ Nakon 1878. godine trgovina iz Bosne i Hercegovine pomjera se prema sjeveru. Zbog toga zadarska komora piše 1884. godine: "Ovaj okrug je prije okupacije obavljao znatan promet s te dvije pokrajine, a danas je u tom pogledu spao na gotovo ništa. Trgovinska politika koja je primijenjena, stvarno je suprotna našim interesima, budući da je sav promet skrenula od južnog prema sjevernom pravcu." ${ }^{41}$ Neki veći promet nije se mogao temeljiti na nesigurnoj cestovnoj vezi, pa se javlja ideja gradnje željezničke pruge koja bi povezala Dalmaciju s Hercegovinom i Bosnom. Ovaj plan zbog političkih razloga nije bilo moguće realizirati do 1878. godine, a i kasnije realizacija ove ideje ide veoma sporo. Interes Monarhije je da trgovina ide prema sjeveru, odnosno prema Ugarskoj.

Ipak, gospodarska suradnja je dala osnovu za razvoj kulturnih, vjerskih i političkih veza Hrvata u različitim pokrajinama. Za vrijeme osmanlijske uprave bilo je čak zabranjeno primati novine iz hrvatskih zemalja. Godine 1851. Omer-paša izdao je zakon: "...Ko bi se našao da prima novine iz kaura, ima se odmah u okov teški metnuti, a njegovo sve imanje

36 Bernard Stuli, "Ekonomsko-društvene prilike u Dalmaciji u XIX. stoljeću", u: Dubrovnik, 3-4, 1962., str. 3-11.

37 I. Karaman, Privreda i društvo..., str. 130. Izvozni artikli su: stoka, žito, vuna, vosak, koža i voće. Uvozi se: ulje, rakija, suhe smokve, sol i manufakturna roba.

38 Isto, str. 14.

39 Isto, str. 131.

40 Grga Novak, Prošlost Dalmacije, II., Zagreb, 1944., str. 369-371.

41 I. Karaman, Privreda i društvo..., str. 137. 
ima se okrenuti u begluk."42 Nije uspio pokušaj Osmanskoga Carstva i Austro-Ugarske Monarhije u stvaranju granične barijere između Dalmacije i Hercegovine i međusobne izolacije ovih hrvatskih prostora. Uz gospodarske razvijaju se kulturne i političke veze, a nakon pobjede hrvatskoga narodnog preporoda u Dalmaciji preporodna ideja jače se osjeća u Hercegovini. Pokušaj Monarhije da preko nadzora graničnoga prometa i kontroliranja prijelaza granice suzbije hrvatski utjecaj iz susjedne Dalmacije nije dao očekivane rezultate. ${ }^{43} \mathrm{Na}$ snazi je bila i zabrana pojedinih listova iz hrvatskih zemalja kao na primjer lista Hrvatska koji je pravaški list. ${ }^{44} \mathrm{U}$ Vrgorcu se sastaju Hrvati iz ljubuškoga kadiluka u kući Danijela Martinca, a odlaze i na brdo Miaču gdje razgovaraju o ustanku i buđenju narodne hrvatske svijesti. ${ }^{45}$

\subsection{Razdoblje nacionalne agitacije i važnost Mostara u tome proce- su za Hrvate u BiH}

Razdoblje znanstvene nacionalne propagande odvijalo se unutar samostana Bosne Srebrene, a tek razdoblje nacionalne agitacije možemo pratiti u Mostaru. Ključna godina za početak ovoga razdoblja je 1872. kada se osniva Bratovština sv. Antuna Padovanskog, ${ }^{46}$ Franjevačka

42 Franjevački arhiv Mostar, IZ/3, f. 30r, Pismo što je Omer-paša poslao fra Andriji Kujundžiću u rujnu 1851. godine. On navodi da neki franjevci vrše dužnosti koje prelaze granice njihova poziva. Provincijal zabranjuje primanje periodike iz Zagreba. Vidi: Tugomir Alaupović, Ivan Frano Jukić, Sarajevo, 1906., str. 11.

43 Tomislav Kraljačić, Kalajev režim u Bosni i Hercegovini 1882.-1903., Sarajevo, 1987., str. 147. Tako je godine 1887. sreski predstojnik u Ljubuškom izjavio da su: "...veliko-hrvatska rovarenja u njihovom korijenu sasječena".

44 Isto, str. 145.

45 Marko Vego, Historija Brotnja od najstarijih vremena do 1879. godine, Čitluk, 1971., str. 258.

46 Marko ŠEšELJ, "25-godišnjica Bratimstva sv. Ante Pad. u Mostaru 1872.-1897.", u: Hrvatska domovina, br. 134, Zagreb, 14. 6. 1897.: "sigurno je da najradosnije može o tome pisati i govoriti samo hercegovački Hrvat ili Mostarac. A kako da on nebi najradosnije na to mislio, kad se to tiče rodnog mu mjesta, koje bi od Mostaraca svaki najradije želio, da što bolje procvati i da se nasladjuje oduševljenom ljubavi, kojom se mi gradjeni okupljamo i okupiti znamo, tako da nam je uvjek na umu Bog i obća zajednica hrvatskoga nam naroda." Nakon uvodnoga dijela on govori o okolnostima u kojima je društvo nastalo. Naglašava važnost apostolskoga vikara fra Rafe Barišića za katolike u Mostaru i Hercegovini. Barišić je u svojoj kući (kod Mostara) okupljao ljude iz cijele Hercegovine gdje se dogovaralo o razvitku narodnom i u tu svrhu ustanovio narodnu zakladu za pomoć u iznosu od 200 kesa (10.000 f.). Poticao je trgovinu i davao zamah svim idejama u Hercegovini, ali nakon njegove smrti 1863. godine sve je to zamrlo. Građanstvo je shvatilo da se treba nešto učiniti po uzoru na muslimane koji 
su za vođu imali učena čovjeka H. Mustafu ef. Karabega. Pravoslavni su počeli uređivati svoju općinu, ali bez statuta (nastavak u br. 135 od 15. 6. 1897.). Građanstvo je 1870. godine bilo pred osnivanjem društva na sastanku u kući Vidaka Šešelja koja je ujedno bila i gostiona. Za mišljenje su pitali apostolskoga vikara fra Anđela Kraljevića, a on se obratio austrijskom konzulu u Mostaru Pavlu Relji za pomoć. On je primio izaslanstvo građana i obećao da će im pomoći oko osnutka bratinstva. Nakon što su izradili pravila, apostolski vikar fra Anđeo Kraljević ih potvrdi 21. svibnja 1872. Pavao Relja je bio predsjednik bratimstva kako se vidi na početku knjige bratimske. (M. Šešelj prilikom pisanja imao je potvrdu pravila u knjizi bratimstva na koju se poziva više puta, op. T. Z.). Ovo je jedino katoličko društvo u Bosanskom pašaluku koje je imalo zadatak razvijati ugled katolika te promicati i podupirati dobrotvorne svrhe. Na čelu društva je fra Frano Bašadur, župnik u Mostaru. On je udario temelje društvu i ono je ubrzo imalo 50-60 obitelji, a sam fra Frano Bašadur bio je redoviti član bratimstva i prvi tajnik. Uz fra Franu Bašadura treba spomenuti i jedan broj građana u Mostaru kao i one u čijim su se kućama održavali sastanci. Bratimstvo je nabavilo svijeće i barjak i iste godine (1872. god.) stupa u procesiji za Tijelovo u Mostaru. Ovo je prva procesija koja je prošla ulicama Mostara i nagovijestila kraj osmanske uprave. Da ne bi došlo do problema, osmanske vlasti su dodijelile počasnu stražu od osmanlijskih vojnika što je bratimstvo uspjelo preko konzula isposlovati od Mutesarifa (okružnog predstojnika) Hasanbega ili Skadranina paše. Radi istine moramo napomenuti da muslimani nisu od tada nikada smetali javne katoličke obrede u Mostaru. Glavna briga Bratimstva sv. Ante Padovanskog je za katolike kako i pravilnik nalaže. Bratimstvo se nije razvijalo kako je bilo za očekivati zbog okolnosti. Fra Frano Bašadur je napustio Mostar, izbio je ustanak nakon čega je došla okupacija. Godine 1885. bratimstvo je imalo samo 15-20 obitelji, a njihovi mlađi članovi su nastavili rad na obnovi bratimstva. Građanstvo je uz pomoć biskupa fra Paškala Buconjića uspjelo potaknuti rad i započelo je izgradnju društvenoga doma. Katolici u Mostaru kao zanatlije imali su više malih društvanaca koja su bila nepovezana i razjedinjena. Kroz godinu dana bratimstvo je s 15 obitelji naraslo na 115, a danas (1897. god.) ih ima i više. Izgradnja Družtvenog doma bila je velika stvar za sve članove. Zasluge Bratimstva sv. Ante Padovanskog su doček vojske Monarhije i kićenje hrvatskim trobojnicama, na procesiji za Tijelovo kićenje hrvatskim trobojnicama, a i osnutak Narodnog pjevačkog družtva i drugih poduzeća sve je to bratimstvo sa svojim članovima dalo ostvariti. "Pitamo li za upliv i zametak sarajevskog narod. pjev. družtva Trebević, tako isto i družtva vareškog Zvijezda, kao i to, da su naši članovi znali vatru ljubavi i sloge piriti diljem Bosne i Hercegovine, te zaslužno odlikovati se u svemu, gdje se tiče obraza i ugleda mostarskih Hrvata, svagdje ćemo dobiti odgovor, da su to sve naši članovi znali i umjeli samo svojim trudom i priegorom raditi i širiti. Nego još jedn. Zar nije uplivala gradnja našeg družtvenog doma, da su ljudi u Bosni naumili na više mjesta slične zgrade podizati, u čem se eto odlikuje prvo Livno, gdje se je naših mostaraka Hrvatica više poudalo." Možemo se ponositi s Bratimstvom sv. Ante Padovanskog na čijoj je zastavi veliki čudotvorac sv. Antun koji nam je vođa. Moramo ovdje istaći da nije bilo pomoći iz Zagreba pa čak ni da novine objave vijest o gradnji doma. Ipak, bilo je iznimaka i pomoć je došla od zagrebačkih gospođa na čelu sa gđicom Zoricom Trnski koje su poslale krasan zastor za dom. Prilikom izgradnje doma nastao je veliki dug od 10.000 for. i bez pomoći sa strane teško da će društvo moći to podmiriti. (Završetak u broju 137, 18. 6. 1897.) 


\section{tiskara, ${ }^{47}$ dolaze časne sestre sv. Vinka iz Maribora ${ }^{48}$ i održana je prva procesija kroz Mostar za Tijelovo (Brašančevo) uz pratnju osmanskih}

47 "Don Frano Milićević (autobiografija)", Osvit, br. 13, Mostar, 14. 2. 1903. Rođen u Velikom Ograđeniku 10. listopada 1835., četvrti sin oca Frane i majke Kate rođene Pehar. Kršteno ime mu je Marijan, a kako su roditelji prešli u Mostar 1842. godine pohađao je školu 1850., 1851. i 1852. godine kod franjevaca. Odlazi na Široki Brijeg u franjevačko sjemenište 1852. godine. (Vidi opširnije: ANTE MARIĆ, Franjevačka klasična gimnazija na Širokom Brijegu od 1844.-1917./18., Hercegovačka franjevačka provincija Uznesenja BMD - Franjevačka knjižnica, Mostar, 2011., str. 49. Najstariji sačuvani popis sjemeništaraca, gimnazijalaca na Širokome Brijegu donosi, dakle, fra Anđeo Kraljević u svome Šematizmu iz 1853., a među trinaest imena nalazimo Marijana Milićevića.) Franjevačku odjeću obukao 15. ožujka 1855. i uzeo ime Franjo, a 15. ožujka 1856. položio redovničke zavjete. Naredne godine odlazi u Perugiu na studij filozofije gdje je obolio. Usprkos bolesti završava filozofske nauke i studira bogosloviju u Narni. Zaredio se za svećenika 19. ožujka 1860., a studij bogoslovije nastavio u Kamerine, ali zbog rata vraća se u domovinu. Jedno vrijeme boravi u Dubrovniku, a onda odlazi u Veljake gdje ostaje do svibnja 1863. godine kada je premješten u Gradniće. Naredne 1864. godine odlazi u Zavojane u Dalmaciju, a 1867. godine u Sv. Martin na Brač kao gvardijan i župnik. Dolazi u Igrane 1868. godine za župnika, a na poziv biskupa Kraljevića, koji se dogovorio s redodržavnikom fra Petrom Kordićem da se osnuje tiskara u Mostaru, dolazi u Mostar 1871. godine i postaje učitelj u pučkoj školi dvije godine. Boravi 1872. godine u Trstu kako bi izučio tiskarstvo i vođenje tiskare, a tu se upoznaje s pravilnicima o radu u kojima su regulirana prava i obveze radnika u tiskari. Kada je utemeljena tiskara 1872. godine, on preuzima vođenje, ali turske vlasti su zaplijenile svu opremu i tražile popis svih knjiga koje će tiskati. Fra Franjo je dao stara književna djela i svoj rukopis Sveto krasnoslovlje koje turska vlast zaprimi i ništa nije povratila. Nakon godinu dana stigne dozvola za tiskanje i da po jedan primjerak svake knjige iz tiskare bude predan u državnu biblioteku. U tiskari je otisnut Schematismus franjevački 1873. u staroj tehnici i izrađen ručnim tiskom jer još radnici nisu bili vješti zanatu.

Ovo je izazvalo protivljenje kod franjevaca i biskupa Kraljevića pa je tiskara postala vlasništvo fra Franje Milićevića. Tiskara je u početku nosila naziv Typographia Missionis Catholicae in Hercegovina, Typografia Franciscana i kasnije Tiskara fra Frane Milićevića u Mostaru. Kako bi se mogao potpuno posvetiti tiskari, fra Franjo je zatražio kod Svete Stolice privremeni istup iz reda da kao svećenik u miru može uzdržavati svoju tiskaru. Godine 1883. dobio je odobrenje da izdaje povijesno-književni list Bosiljak čiji je prvi broj izišao 1. rujna 1883. Nakon nepune godine dozvola je oduzeta, a nakon tri mjeseca dobio je drugu dozvolu i počeo izdavati list Novi Hercegovački bosiljak. List je postao politički 1885. godine kada je promijenio ime u Glas Hercegovca. List je u duhu hrvatskoga prava uređivao don Frano Milićević i dao je veliki doprinos razvitku i procvatu hrvatske misli u Herceg-Bosni. Nakon što je obolio 1895. godine urednikom je postao N. Radičić koji ga uređuje od početka 1896. godine do srpnja 1896. godine kada prestaje izlaziti. Nakon kraće stanke osniva se 1898. godine Osvit pod uredništvom sinovca Frane Milićevića Ivana A. Milićevića. Prilikom svoje zadnje službe na Buni pokušao se vratiti u franjevački red, ali smrt ga je pretekla u toj nakani. Umro je 8. veljače 1903., a pokopan na groblju Šoinovac (Vidi opširnije: Ivan AlıLović, Tri zaboravljena imena, Zagreb, 1974., str. 16).

Brojni autori su pisali o tiskari i don Frani Milićeviću, a u autobiografiji su mnoga pitanja ostala nedorečena i otvorena za daljnja istraživanja. Budući da je urednik bio Ivan A. Milićević i neke tvrdnje iz autobiografije trebaju se provjeriti na osnovi drugih dokumenata.

48 Osvit, br. 31, Mostar, 9. 9. 1898. 
oružnika. ${ }^{49}$ Ovi događaji označit će početak novoga doba za katolike u Mostaru, a grad će se početi mijenjati i pretvarati u jedan od važnih kulturnih centara u ovome dijelu Europe.

Tiskara je morala preboljeti "dječje bolesti" zbog skromnih tehničkih i ljudskih potencijala i dočekati dolazak Austro-Ugarske Monarhije u Hercegovinu kako bi bila spremna na izdavanje lista Hercegovački bosiljak 1883. godine..$^{50}$ Nedostatak kvalificiranih radnika, novca kao i problemi oko vlasništva utjecali su na tiskaru koja je stalno bila na rubu održivosti, ali upornost don Frane Milićevića nadišla je sve te okolnosti i uspjela opstati i postaviti temeljni kamen tiskarstvu, izdavaštvu i novinarstvu u Hercegovini.

U drugoj polovici XIX. stoljeća na prostoru Hercegovine ime don Frane Milićevića jedno je od najznačajnijih unutar procesa nacionalne integracije Hrvata. Sve poteškoće koje je podnosio da bi postigao svoj cilj oslanjajući se na čvrstu volju, marljivost i ustrajni rad dat će na kraju željeni rezultat. Sam don Frano Milićević nije se isticao velikom učenošću, vanjštinom, rječitošću, bogatstvom i odijelom, ali on je bio: "... jedna od najvažnijih ličnosti u narodnoj borbi, u našem preporodu u Herceg-Bosni. Ali don Frano je ljubio i radio. Žarka i neugasiva ljubav za hrvatsku stvar, za hrvatske svetinje, za misao jedinstva i slobode silila ga je na uztrajan i neumoran rad. To je, što je našega don Franu učinilo u istinu velikim medju nama." ${ }^{11}$

49 Marko ŠEšELJ, "25-godišnjica Bratimstva sv. Ante Pad. u Mostaru 1872.-1897.", u: Hrvatska domovina, br. 134, Zagreb, 14. 6. 1897.

50 Prvi broj izašao 1. 9. 1883., ABiH, Zemaljska vlada br. 12260 od 13. 7. 1883.; Risto Besarović, Kultura i umjetnost pod austrougarskom upravom, Sarajevo, 1867., str. 422. Novine je uređivao F. Milićević, a upravitelj je Stjepan Dragoni. Neki dijelovi tiskani ćirilicom, a ostalo latinicom. List je bio za zabavu, pouku i književnost. Ubrzo je zabranjen odlukom Visoke zemaljske vlade od 22. 6. 1884., br. 746/res. F. Milićević se žali i traži dozvolu za Novi Hercegovački bosiljak što mu je i dopušteno 23. 7. 1885., ABiH, ZMF, br. 4436, Pr. BH, 1885. List je bio kvalitetniji i raznovrsniji. Izlazio je subotom, a prvi broj izašao je 3. siječnja 1885. Urednik je F. Milićević, a upravitelj i izdavatelj u Metkoviću Stjepan Dragoni. Vidi: Novi Hercegovački bosiljak, br. 1, Mostar, 3. 1. 1885., a br. 37, 12. 9. 1885.; "Naš program", u: Novi Hercegovački bosiljak, br. 35, Mostar, 29. 8. 1885. "Budući da će Glas Hercegovca postati kao baštenik Novog Hercegovačkog bosiljka skupljat će po narodu našemu, zakopano bogatstvo našeg milozvučnog jezika, te narodne pjesme, pripovjetke, itd. priobćavat će u svom podlistku. Pri nacrtanoj zadaći, mislimo da ćemo svetu dužnost prema svom narodu vršiti, da naš narog neće se pokajati za svoju podporu, da će svi svjestni rodoljubi biti nam desna ruka, podupirajući nas svjetom i perom, eda umirimo, složimo i napred potisnemo zapuštenu postojbinu našu. Mi ćemo s naše strane nastojati list što ukusnije izdavati i povećavati, kako ga evo sad povećasmo, a ciena predbrojnikom ostaje ista."

51 "Don Frano Milićević", u: Osvit, br. 12, Mostar, 11. 2. 1903. 
Boraveći u Italiji uvidio je što znači borba za ujedinjenje naroda i jedinstvo domovine, a to mu je bio putokaz za svoj narod. Poslije povratka u domovinu uvidio je da je njegov narod, osobito onaj u Herceg-Bosni, gotovo zaboravio svoju prošlost i da je u njemu zamrla narodna svijest.

Kada je uspio pokrenuti tiskaru, ona je postala temeljni kamen za rad na prosvjetnom, kulturnom i narodnom polju. Nakon dolaska Monarhije stvaraju se uvjeti za izdavanje listova koji su bili u duhu hrvatskih preporoditelja. Brojne poteškoće $s$ kojima se susretao nisu ga zaustavile, nego samo usporavale na njegovu putu razvitka narodne ideje i prosvjete. Uz pomoć Ivana Zovke i fra Jerke Ljubića, preko Glasa Hercegovca, ${ }^{52}$ dokazivao je da je Herceg-Bosna kolijevka Hrvatstva. Stranka prava u svome je programu uključila Bosnu i Hercegovinu u hrvatske zemlje i aktivnije se počela baviti prilikama u njoj 1894. godine. Ona je propagirala hrvatsku državnu misao, a don Frano se stavlja na raspolaganje i prima povjerenstvo stranke. Oko sebe je sakupljao mlade snage: redovnike, studente i učitelje te na njih prenosi svoje oduševljenje za hrvatsku narodnu stvar u Herceg-Bosni. Razočaranje Nedjeljkom Radičićem nakratko ga zaustavlja, kao i voljeni list, ali uz pomoć sinovca Ivana A. Milićevića tiska se Osvit ${ }^{53}$ koji će nastaviti borbu za hrvatsku narodnu stvar.

Prva etapa u radu tiskare bila je od osnutka do 1883. godine kada je uglavnom tiskala djela u malim nakladama. Broj izdanja kretao se od jedne do jedanaest knjiga u 1874. i 1875. godini pred ustanak. Ovo možemo objasniti početkom rada, nedostatkom kvalificiranih radnika, nedostatkom tiskarskoga materijala, novčanim problemima i malom nakladom djela koja su tiskana. Druga etapa je započela kada je pokrenut list Hercegovački bosiljak, koji je označio početak jednoga novog doba kao i početak

52 Glas Hercegovca, br. 38, od 19. 9. 1885. izlazio do 1896. godine. Izlazio je jedanaest godina i bio političko glasilo Hrvata u Bosni i Hercegovini.

53 Osvit, br. 1, Mostar, 27. 7. 1898., izlazi do br. 72, 2. srpnja 1908.; "Kojim putem?", u: Osvit, br. 2, Mostar, 30. 7. 1898.; "Naš je program čisto hrvatski, na njemu se osniva čitav naš rad. A taj rad smjera na to, da nam bude konačno i trajno mjesto, život, zajednica s ostalom našom hrvatskom braćom u monarhiji. U tom okviru mi ćemo raditi, u tom okviru hoćemo da ostanemo i nema sumnje, daće taj rad, to nastojanje uroditi plodom, koji svi očekujemo... Tim ćemo putem ići, sviestni, da tim vršimo najsvetije dužnosti prama otačbini i svom narodu i s toga nas puta ne će moći nitko odvratiti." U zaglavlju ispod naziva novina kao moto bili su stihovi Safvet-bega Bašagića:

"Hrvatskog jezika šum

Može da goji

Može da spoji

Istok i Zapad, pjesmu i um!" 
novinarstva kod Hrvata u Hercegovini. Ponovo je bilo problema jer je bilo zabranjeno pisati o politici, te cenzurom i nedostatkom suradnika koji su vični novinarskoj profesiji. Radnici u tiskari morali su brzo raditi da bi novine mogle redovito izlaziti. Mali broj pretplatnika kao i skromna tiraža lista bili su ograničavajući čimbenici. Sve je ovo trebalo nadići i nastaviti rad na izdavanju Hercegovačkoga bosiljka dok ga vlast zabranom nije dokinula. Don Frano Milićević ne posustaje nego traži dozvolu za pokretanje lista Novi Hercegovački bosiljak.

Glas Hercegovca u svome prvom broju od 6. siječnja 1894. obilježio je desetogodišnjicu izlaženja novina u Mostaru: "Evo se već 10 godina navršilo, da kako je naš list počeo izlaziti; najprije, pod, naslovom Hercegovački Bosiljak pa Novi Hercegovački bosiljak i napokon Glas Hercegovca. Ta tri imena, ipak od postanka imala jedno načelo, a potpomagali su ih čestiti i sviesni Hrvati rodoljubi, naši mili otačbenici Hrvati, kao jedino pravo i valjano hrvatsko glasilo Herceg-Bosne.

Deset punih godina stoji čvrsto Glas Hercegovca usred toliko neprilika i nepogoda. Pa ako je i bilo časova, u kojima su se naši raznovrsni protivnici poveselili, da će ga ponestati bez traga i glasa, to se je svaki put, naš list na časak klonuvši, podigao još jače, još smjelije i još odlučnije na borbu, za našu milu domovinu, za naše hrvatstvo, za onu uzvišenu ideju, koju više nitko ne iztrga iz srca hrvatskog naroda... da ćemo se i nadalje moći uzdržati pogotovo sada, kad je hrvatska preporodjena, misao i sviest zahvatila čvrst koren u narodu... I zato želimo i nadamo se, da će se sviestni Hrvati shvativši cilj našega lista- kao jedinoga hrvatskog glasila Herceg-Bosne - okupiti oko našeg lista, oko Glasa Hercegovca pa će ga podpomagati riečju i djelom." ${ }^{54}$

Franjevci, zajedno s hrvatskim narodom, postaju nositelji procesa hrvatske nacionalne integracije u Mostaru i čitavoj Hercegovini. Članak u Osvitu "Recimo i mi svoju!" donosi: "Buđenje narodne svijesti u Banovini (ilirizam) kod nas samo odjeka kod inteligentnih pojedinaca u narodu nije razvio... Hrvati na čelu s franjevcima, ustadoše u obranu imena svog i narodnog ponosa. Počeše narod buditi, narod po gradovima stade se buditi i braniti svoje narodne svetinje... Tada se po gradovima okuplja mladež i prijatelji na sastanke na kojima se pjeva narodna pjesma, a mladež poticala i zagrijavala za narodne ideale. Iz ovih sastanaka nicala su narodna pjevačka društva i u njima se širi narodna svijest. Srbi su napadali hrvatsku ideju u Bosni i Hercegovini, a hrvatstvo nije nitko pomogao. Glas Hercegovca ukinut, ali se uskoro na hrvatskom braniku Herceg-Bo-

54 "Poslie 10 godina", u: Glas Hercegovca, br. 1, Mostar, 6. 1. 1894. 
sne pojavio Osvit." ${ }^{55}$ Monarhija je nakon dolaska zabranila uporabu hrvatskoga narodnog imena, grba i trobojnice pa se javlja katoličko ime sve do prestanka zabrane 1899. godine, kada hrvatsko ime zamjenjuje katoličko. ${ }^{56}$ Bosanska zemaljska vlada dala je dozvolu da društvo Trebević nosi naziv Hrvatsko pjevačko društvo Trebević, a Hrvoje mostarsko hrvatsko pjevačko društvo. ${ }^{57}$ Nešto poslije Osvit donosi članak pod naslovom Rad za hrvatstvo: "Pjevati hrvatske pjesme, učiti hrvatsku povijest, dolaziti u doticaj s narodom, raditi za dobro naroda, da se ponosi i diči imenom Hrvat, da u narodu raspalimo domoljubnu ideju, podizati škole i čitaonice te pjevačka društva... učiti ga da je HRVAT." ${ }^{58}$ Osnivanjem društava i organizacija koje nose hrvatsko ime prodire u hrvatski narod koji postaje svjestan svoje nacionalne pripadnosti. Franjevci su još godine 1872. osnovali Pobožnu zadrugu svetog Ante Padovanskog i iz ovoga društva poslije će se osnovati nova katolička društva u gradu i cijeloj Hercegovini. Najznačajnije društvo koje su osnovali mostarski Hrvati je Narodno hrvatsko glazbeno $i$ pjevačko društvo Hrvoje. ${ }^{59}$

Kako su političke organizacije bile zabranjene, tu ulogu preuzimaju pjevačka društva koja djeluju među Hrvatima u Hercegovini. Biti član društva bila je velika čast, a dirigenti i vođe sekcija imali su veliki utjecaj na hrvatsku omladinu odgajajući je u nacionalnome duhu. Među članovima Hrvoja koji su se isticali umjetničkim radom bili su: Rafo Šapina, Zvonko Pezelj, Vinko Goatti, Puba Markulin, Adolf Belobrk, Grga Smoljan, Nikica Fertilo, dr. Franjo Bulat, Đuro i Franjo Pezelj, Martin Čule, Vinko Šubir, fra Anđeo Nuić, fra Augustin Zubac, fra Ambro Miletić i Augustin Remec. ${ }^{60}$ Prilikom proslava u hrvatskim zemljama ili podizanja spomenika istaknutim pojedincima iz hrvatskoga naroda, primjerice Strossmayeru, Kumičiću i Mihanoviću, ${ }^{61}$ u Mostaru se organiziraju prigodni koncerti njima u čast. Periodika u Hercegovini redovito donosi vijesti o nastupima i gostovanjima pjevačkih društava. Najavljuju se sve aktivnosti uz rad $\mathrm{Hr}$ voja i drugih društava, a ima i komentara o održanim priredbama, na razini informacije, bez glazbene kritike.

55 "Recimo i mi svoju", u: Osvit, br. 25, Mostar, 27. 3. 1901.

56 Luka Đaković, Političke organizacije bosanskohercegovačkih katolika Hrvata, Globus, Zagreb, 1985., str. 167-175.

57 "Hrvatsko ime", u: Osvit, br. 2, Mostar, 4. 1. 1899.

58 "Rad za hrvatstvo", u: Osvit, br. 95, Mostar, 25. 11. 1899.

59 "Glavna godišnja skupština Hrvoja", u: Osvit, br. 23, Mostar, 12. 10. 1898.

60 Spomenica o 50-godišnjici pjevačkoga društva Hrvoje u Mostaru, Mostar, 1938., str. 7-23.

61 "Iz Hrvoja", u: Osvit, br. 34, Mostar, 13. 4. 1907. 
Glas Hercegovca prati tri bitna događaja iz 1891. godine na kojima su sudjelovali Hrvati iz Bosne i Hercegovine: otkrivanje spomenika Kačiću u Zagrebu, Gaju u Krapini i Hrvatsko-slavonska poljodjelsko-zanatska izložba. ${ }^{62}$

Osvit stalno ističe da se pjevačka društva i čitaonice otvaraju među Hrvatima u Bosni: ${ }^{63}$ Brčkom, Varcar Vakufu, D. Tuzli, Travniku, Banjoj Luci, Kiseljaku i Varešu kako bi probudili narodnu svijest. Brinući se za boljitak Hrvata u Bosni i njihovo napredovanje, preporodna ideja širi se iz Mostara i Hercegovine u Bosnu. Prilikom prigodnih obljetnica, aktivno sudjeluju u njima s nacionalno obojenim programom, koji je i u funkciji procesa nacionalne integracije. Obilježavaju 25. godišnjicu biskupovanja fra Paškala Buconjića i 80. rođendan hrvatskoga pjesnika fra Grge Martića. Preko svojih zastupnika sudjeluju na otkrivanju spomenika Dživu Franu Gunduliću 1892. godine ${ }^{64}$ jer je Hrvoju zabranjen udjel u proslavi, a uime mostarskih Hrvata položili su lovorov vijenac. Nakon svečanosti 1900. godine i posvećenja zastave Trebevića u Sarajevu sudjeluje i Hrvoje. Prilikom povratka sudionika s hrvatske proslave u Sarajevu u Mostar dolaze: Sokol iz Kostajnice, Jadranska Vila, narodni zastupnici Trumbić, Smodlaka i Modrušanin. U Mostaru je priređeno veliko sijelo "...da bi se na zoran način predočilo jedinstvo misli, želja i osjećaja između HercegBosne, dalmatinske i banovinske Hrvatske". ${ }^{65}$ Trebević je uzvratio posjet Hrvoju početkom 1901. godine ${ }^{66} \mathrm{~s}$ ciljem širenja hrvatske prosvjete i buđenja nacionalne svijesti, koja se tako iz Hercegovine širi prema Bosni kako bi došlo da ujedinjenja svih Hrvata i stvaranja zajedničkoga društva Trebević i Hrvoje "skupljeni pod jednom zastavom, na kojoj je napisano Bog i Hrvati!"67

Matica hrvatska, još jedna od hrvatskih institucija koja je nazočna u Bosni i Hercegovini i čiji rad sustavno prati Osvit, tijekom 1898. godine ukupno ima 11.067 članova, ${ }^{68} \mathrm{a}$ iz Hercegovine je u Ljubuškom 22, Trebinju 34 i Mostaru 95 članova koji su primili matičine publikacije i aktivno sudjelovali u njezinu radu. Prvi član iz Bosanskoga pašaluka, godine 1877.,

62 "Hrvatska izložba u Zagrebu", u: Glas Hercegovca, br. 52, Mostar, 19. 9. 1891.; "Spomenik Ljudevitu Gaju", u: Glas Hercegovca, br. 69, Mostar, 14. 10. 1891.; L. ĐА коvić, Političke organizacije bosanskohercegovačkih katolika Hrvata, str. 167.

63 "Komentar", u: Osvit, br. 83, Mostar, 14. 10. 1899.

64 Spomenica o 50-godišnjici..., str. 19.

65 Isto.

66 "Trebević i Hrvoje", u: Osvit, br. 8, Mostar, 26. 1. 1901.

67 "Iz naših družtava", u: Osvit, br. 11, Mostar, 6. 2. 1901.

68 "Broj članova Matice hrvatske", u: Osvit, br. 31, Mostar, 9. 11. 1898. 
postao je Jeronim Vladić, ${ }^{69}$ profesor bogoslovije iz Livna. Krajem XIX. stoljeća broj članova Matice hrvatske u Bosni i Hercegovini popeo se na oko 900, što govori o velikome interesu, a u Hercegovini su članovi iz Mostara, Trebinja, Ljubuškoga i Nevesinja. ${ }^{70}$

Osvit uz Hrvoja prati i podupire djelovanje mostarskoga hrvatskog društva Sokol..$^{71}$ Osnivanjem ovoga društva udareni su temelji razvoju tjelesne kulture i športa u Hercegovini. Društvo je osnovano 1896. godine, a 1902. promijenilo je naziv u Koturaško gombalačko društvo Sokol u Mostaru. U članku pod nazivom Sokolska večer, Osvit piše: "Uz razvoj tijela razvija se i hrvatski duh, svijest i rodoljublje."72 Učitelj vježbanja, Adam Škrtić, poziva nove članove u društvo: "Budimo sokoli na ponos našoj miloj hrvatskoj domovini."73 $\mathrm{Da}$ se u proces nacionalne integracije uključuju i ruralni prostori, svjedoči nam dopis iz Ljutoga Doca o pučkoj svečanosti 26. srpnja 1900. gdje je nazočan velik broj seljaka: "Okićeni hrvatskim trobojnicama. Primite hrvatski pozdrav."74

Osvit je odigrao veliku ulogu u razvitku kulture u hrvatskome narodu i često su oni koji su znali čitati prenosili onima koji nisu znali. Tako saznajemo da je na Širokome Brijegu umro fra Jakov Kraljević, koji je često čitao i čuvao brojeve Osvita župljanima koji nisu bili pismeni i na taj način radio na uzdizanju seljaka. ${ }^{75}$

Tisak prati sve događaje u Hercegovini, a posebno napredak na kulturnome polju. Uz franjevački samostan na Humcu otvorena je 1884. godine ${ }^{76}$ prva muzejska institucija u Bosni i Hercegovini, a nakon četiri godine, 1888., bio je otvoren Zemaljski muzej u Sarajevu. U Glasu Hercegovca iz 1890. godine doznajemo o novome muzeju koji je zaslugom fra Anđela Nuića od 1884. godine započeo sa skupljanjem zbirke koja se u međuvremenu povećala, tako da je otvorena još jedna soba s eksponatima. "To je prvi temelj, koga kršna Herceg zemlja zapamti iza silne oluje, koja se je za toliko vjekova izljevala povrh nas, i u bezdanu propast turala, u kojoj ne samo kultura nemogaše proklijati, dapače svakovrstne starine i znameni-

69 Branka Balvanović, "Naša matica", u: Hrvatska misao, br. 3-4, Zagreb, 1997. str. 199.

70 Isto.

71 "Sokol u Mostaru", u: Osvit, br. 50-51, Mostar, 28. 6. 1902.

72 "Sokolsko večer", u: Osvit, br. 42, Mostar, 16. 5. 1907.

73 "Iz hrvatskog sokola", u: Osvit, br. 7, Mostar, 17. 1. 1907.

74 "Pučka svetčanost", u: Osvit, br. 58, Mostar, 28. 7. 1900.

75 Isto.

76 Sto godina muzeja na Humcu, Humac, 1984., str. 40-78. 
tosti težiše na propast, što na veliku sreću evo se porodiše vremena u kojih se i kultura poče cvjetati, i svaka znamenitost može se učuvati. Uvjeren sam, da bi mnogima milo bilo saznati vrste te prve starinarske sbirke Franjevačke, a to bi lasno mogli udovoljiti, kad bi kratkim opisom po jedine predmete ocrtali i malim troškom na svjetlost izdali."77

Nakon otvaranja tečaja iz glazbe prvi su polaznici bili fra Božo Ostojić, fra Anzelmo Čulina, Petar Ivanković i Ivan Radoš. Josip Beraković je godine 1892. otvorio privatnu glazbenu školu u Mostaru u kojoj je podučavao sviranje glasovira, violine i pjevanje. ${ }^{78}$ Svekolika glazbena aktivnost Hrvata u Hercegovini bila je rezultat gospodarskih promjena u društvu koje se sada može posvetiti kulturnom uzdizanju, ne samo uskoga kruga, nego i širokih narodnih slojeva. Hrvoje je kroz glazbu ukazivao na hrvatsku narodnu orijentaciju, koja mu je i misao vodilja, kako bi se hrvatsko ime proširilo u narodu.

Izbijanjem ustanka i odlukom Berlinskoga kongresa 1878. godine započet će četrdesetgodišnje razdoblje nazočnosti katoličke Monarhije na ovome prostoru. Dolazak Austro-Ugarske Monarhije u Bosnu i Hercegovinu prošao je uz manje otpore Osmanlija, a nakon uspostave nove vlasti Hrvati nisu dobili priželjkivani status. Pokušaj Benjamina Kalaya da uvede bošnjačku naciju i zabrani uporabu hrvatskoga imena nije dao rezultata. Prve godine protekle su u zabranama brojnih manifestacija koje su imale nacionalni predznak i obilježja.

Odnos nove vlasti prema Hrvatima zorno se vidi u odnosu prema studentima iz Bosne i Hercegovine koji su na različite načine ometani u studiju na Sveučilištu u Zagrebu. Do 1892. godine nema studenta iz Bosne i Hercegovine u Zagrebu, a te godine studij upisuje 41 student. Školske godine 1893./1894. studij je upisalo više od 100 polaznika. ${ }^{79}$ Česti izleti Hrvata iz Mostara u Dalmaciju zbližavali su hrvatski narod koji je razdvojen umjetnim granicama. Tako Osvit piše: Trgovci odlaze u Ston. Zavjet u Podgoru. Prilikom putovanja došlo je do incidenta zbog pjevanja hrvatskih pjesama i hrvatske trobojnice. ${ }^{80}$ Hrvati iz Dalmacije rade na izgradnji željezničke pruge od Ilidže do Kobiljeg dola za potrebe

77 "Iz Nahije", u: Glas Hercegovca, br. 9, Mostar, 26. 2. 1890.

78 "Privatna glasbena škola", u: Osvit, br. 43, Mostar, 21. 12. 1898.

79 L. ĐAкоvić, Političke organizacije bosansko hercegovačkih katolika Hrvata, str. 160. Stipendije davane za studij u Austriji, a u Zagrebu se studiralo o osobnom trošku. Samo je mali broj studenata iz Hercegovine mogao to sebi omogućiti.

80 Osvit, br. 9, Mostar, 24. 8. 1889., str. 5; "Mostarski Soko u Metkoviću", u: Osvit, br. 32, Mostar, 22. 4. 1903., str. 3. 
izgradnje pilane G. Feltrinellia iz Italije. ${ }^{81}$ Svi ovi navedeni primjeri bili su integrativni činitelji koji su zbližavali i stvarali svijest o zajedništvu Hrvata. Prilikom brojnih manifestacija Hrvata u Dalmaciji nazočni su Hrvati iz Hercegovine, s trobojnicama i hrvatskim pjesmama, a iz Dalmacije dolaze stručnjaci i radnici na izgradnju željezničke pruge. Pratilo se stanje u ostalim hrvatskim zemljama i proslavljao se svaki hrvatski uspjeh pa čak i osnivanje Hrvatskoga pripomoćnog društva u Beču 25. kolovoza 1886., o čemu Glas Hercegovca opširno piše i donosi Štatut hrvatskog pripomoćnog družtva u Beču u broju 49. od 4. prosinca 1886. Društvu može pristupiti svaki Hrvat. Prate i rad Hrvatskoga akademskog društva Zvonimir u Beču koje izdaje Proglas na hrvatsku omladinu ${ }^{82}$ i u kojem poziva na izdavanje književnoga almanaha. ${ }^{83}$ Glas Hercegovca slao je svoje brojeve društvu Zvonimir u Beču, na čemu Hrvatsko akademsko društvo Zvonimir i zahvaljuje u br. 4. od 23. siječnja 1886.

Budnim okom prate sve što se događa u susjednim hrvatskim pokrajinama, a posebice političke prilike. Prate se događaji oko izbora u Dalmaciji, a iz dopisa iz Imotske krajine od 12. siječnja 1888. doznajemo o sukobu s autonomašima i njihovoj prevrtljivoj i lukavoj politici i pozivaju se na brošuru Hrvati i Talijanaši u Imotskoj krajini. ${ }^{84} \mathrm{O}$ tom sramotnom savezu narodnjaka s talijanašima nailazimo na reagiranja u dopisu Iz Dalmacije od Pravaša na straži koji donosi stanje u Narodnoj stranci nakon smrti Mihovila Pavlinovića. ${ }^{85}$ Dopisom Iz Neretve od 20. svibnja 1887. opisuje se pogreb don Mihovila i naglašava njegova velika briga za narod te da su mu zadnje riječi bile Bože, spasi Hrvatsku.$^{86} \mathrm{Na}$ misi zadušnici bio je prisutan i biskup Paškal Buconjić.

Prati se stanje u Istri što saznajemo iz dopisa "Hrvatski jezik u Istri" u Glasu Hercegovca, br. 39 od 3. listopada 1888., gdje doznajemo za probleme prilikom dopisa na hrvatskome jeziku upućenog poglavarstvu općine Žminj, koja je odbila primiti dopis. Redovito se donose izvješća o radu

81 Osvit, br. 31, Mostar, 9. 11. 1898.

82 "Proglas na hrvatsku omladinu", u: Glas Hercegovca, br. 2, Mostar, 9. 1. 1886.

83 Arhiv franjevačkog samostana Svetoga Duha u Fojnici, XXII Literaria K-24., Pravila literarnog društva hrvatskih franjevaca, Beč, 10. studenog 1907.; Dragutin Ikić, predsjednik, a tajnik Mladen Ćutić.

84 "Iz Imotske krajine", u: Glas Hercegovca, br. 3, Mostar, 24. 1. 1888.

85 "Iz Dalmacije", u: Glas Hercegovca, br. 8, Mostar, 25. 2. 1888.; "Iz Dalmacije", u: Glas Hercegovca, br. 9, Mostar, 29. 2. 1888.

86 "Don Miho Pavlinović", u: Glas Hercegovca, br. 21, Mostar, 28. 5. 1887. i br. 22, 4. 6. 1887. 
Istarskoga sabora ${ }^{87}$ i ponašanju talijanaša, o čemu se donosi opširan prilog "Irredentisti u Istriji"88 $\mathrm{u}$ kome se osuđuje njihovo ponašanje. $U$ povodu otvaranja hrvatske gimnazije u Pazinu, Osvit pod naslovom "Nova hrvatska pobjeda" piše: "Naša hrvatska braća u Istri moraju da izdržavaju tešku borbu s talijanašima. Oni se protive svakom i kulturnom uspjehu hrvatske nam braće." ${ }^{.89}$

Imamo i slučajeva da posjetitelji iz Dalmacije nisu uvijek imali dobre namjere, nego su bili pljačkaši i lupeži, pa tako saznajemo da su Ivan Kilić i Luigi Vrdoljak iz Imotskoga i Marko Vrlika iz Vrlike nanijeli štetu biskupu Buconjiću u iznosu od 8000 forinti, ${ }^{90}$ a slučaj je završio na sudu u Splitu i osuđeni su svaki na 7 godina te su morali biskupu isplatiti 7000 forinti i sudske troškove. ${ }^{91}$

Brojne su bile opcije kako povezati Mostar s Dalmacijom. Nekoliko opcija je bilo ponuđeno: jedni su bili za vezu sa Splitom preko Imotskoga, druga mogućnost je bila veza s Dubrovnikom, treća opcija je izlaz u Kleku. Sve ove opcije su odbačene i odlučeno je da se Mostar poveže s Metkovićem..$^{92}$ Nakon uspostave željeznice između Mostara i Metkovića, koja je svečano puštena u promet 13. lipnja $1885 .{ }^{93}$ bilo je i problema u odnosima stanovnika duž granice između Hercegovine i Dalmacije o čemu saznajemo iz članka "Svakom svoje". ${ }^{94}$ Polemika s dopisnikom Narodnog lista iz Zadra oko ispaše i siječe drva u Hercegovini. Pitanje granice i prava dovelo je do svađe "...kako se Hrvati kolju međuse; to častni dopisniče nije uljudno! mi smo dosti vaši neprilika progutali, a Vi dopisniče kao što i vaši sumišljenaci, u čem nas zadovoljiste? Ako niste zadovoljni sadašnjom medjom, vi bar pustite da bude onuda kudaje bila u vrieme Mujino..." ${ }^{95}$ Zahtjev je iz Dalmacije da imaju pravo na ispašu i sječu drva još 10 kilometara iza granice na što Hercegovci ne pristaju. Brojni Hrvati putuju u Mostar i šalju svoje dopise u Osvit "...dalmatinski

87 "Irredentisti u Istri", u: Glas Hercegovca, br. 47, Mostar, 27. 11. 1889.

88 Isto.

89 "Nova hrvatska pobjeda", u: Osvit, br. 17, Mostar, 25. 2. 1899.

90 "Buconjić", u: Glas Hercegovca, br. 11, Mostar, 19. 3. 1887.

91 "Lična viest", u: Glas Hercegovca, br. 12, Mostar, 26. 3. 1887.

92 I. JURIĆ, Gospodarski razvoj luke i trgovišta Metković..., str. 80-98.

93 "K otvoru željezne pruge Mostar-Metković", u: Novi Hercegovački bosiljak, br. 24, Mostar, 13. 6. 1885. "U oći i na dan otvorenja željezničke pruge Mostar-Metković, u: Novi Hercegovački bosiljak, br. 26, Mostar, 27. 6. 1885. do broja (u nastavcima) 29, 18. 7. 1885.

94 "Svakom svoje", u: Novi Hercegovački bosiljak, br. 33, Mostar, 15. 8. 1885.

95 Isto. 
Hrvat prolazi kroz kršnu Hrvatsku Hercegovinu. Kao i Mije Pavlinović da vidi braću u borbi za narodni opstanak... Ponosan na Hrvate u Mostaru... U kavanama nema hrvatskih listova. Pravi Dalmatinac." ${ }^{16}$ Brojni posjetitelji iz hrvatskih zemalja borave u Mostaru i Hercegovini pa tako saznajemo da su od 18. do 20. listopada 1898. boravili u Mostaru: Ivan Paić iz Metkovića, Marin Marović iz Starigrada, Blaž Ivanišević iz Metkovića, Grgo, Cvitko i Martin Mustapić iz Lovreća, Karlo Metlika iz Zadra i Fran Šepić iz Kastava, što govori o povezanosti Hercegovine s ovim krajevima. Kada pogledamo pretplatnike Glasa Hercegovca, onda vidimo mjesta kao Knin, Đakovo, Omiš, Zagreb, Beč, Budimpešta, Novi Sad, Prijedor i Ulog, ${ }^{97}$ što govori o velikom teritoriju gdje je list dolazio i donosio vijesti iz Hercegovine. Prilikom otvaranja prosvjetnoga zavoda, koji treba prosvjetljivati i oplemenjivati hrvatski narod, govorio je fra Radoslav Glavaš: "Mi se nikomu ne namećemo, niti koga silimo, da bude s nami, ali svakome je prosto, tko hoće, da bude čovjek, ali pravi plemeniti čovjek." ${ }^{98}$ Osvit u br. 30, od 12. travnja 1899. prenosi članak iz Hrvatskog prava pod naslovom Hrvatska slava u Mostaru: "Kršna Hercegovina, divni taj kraj kraljevstva hrvatskog... Hercegovački Hrvati dugo su se borili za pravo, da mogu svoje narodne osjećaje slobodno ispovijedati. Izlazi Osvit koji njeguje, brani i širi hrvatsku misao. Osvit je glasilo hrvatske braće u Hercegovini. Otkad je taj list počeo izlaziti, on je služio samo hrvatstvu. Njegova je zastava čisti hrvatski pravac, sveta hrvatska misao." Brojni brzojavi pojedinaca, udruga i društava stigli su u redakciju Osvita s čestitkama, a posebno izdvajamo jedan: "Rieka. Braćo dielite i naše veselje prigodom hrvatske proslave. Jakovljević Hercegovac, Jurić Dalmatinac i Gazinja Istranin."99 Čestitajući dolazeću 1900. godinu naglašavaju jedinstvo i ujedinjenje Hrvata. "S toga se nadajmo, da će i opet sadašnje nesloge medju pojedinim sinovima hrvatskog naroda brzo nestati, a mi svi složni i jaki steći svoju zasluženu plaću - jedinstvo i slobodu Hrvatske domovine. Do tog cilja neka svatko radi, koliko može, ali taj rad neka bude nesebičan, otvoren, čist, neka bude pravi hrvatski, a u to ime-još jednom: Čestita i sretna nova godina svim Hrvatima!"100

96 "Dopis", u: Osvit, br. 91, Mostar, 11. 11. 1899.

97 "Odpisi Glasa Hercegovca", u: Glas Hercegovca, br. 38, Mostar, 22. 10. 1887.

98 "Hrvatska proslava", u: Osvit, br. 29, Mostar, 8. 4. 1899.

99 "Brzojavne izjave", u: Osvit, br. 31, Mostar, 15. 4. 1899.

100 "Čestita nova godina 1900.", u: Osvit, br. 104, Mostar, 30. 12. 1899. 
Kada govorimo o zaslužnim Hrvatima u Mostaru, tijekom procesa nacionalne integracije, ističu se tri imena: don Frano Milićević, Ivan Zovko $^{101}$ i Ante Jukić. ${ }^{102}$

\subsection{Razdoblje masovnoga nacionalnog pokreta}

Početak završnoga razdoblja procesa nacionalne integracije uočavamo već u prvom desetljeću XX. stoljeća kada se u Hercegovini u proces nacionalne integracije uključuje i hrvatski seljak kao najbrojnija sastavnica narodnoga bića, koja čini preko $80 \%$ populacije. Inzistiranje franjevaca, inteligencije i građanstva na uključivanju hrvatskoga seljaka u analfabetske tečajeve, društva, čitaonice i posjet predstavama dalo je rezultat. Poboljšao se materijalni položaj seljaka, koji sada može školovati svoju dje$\mathrm{cu}$, a zahvaljujući napretku poljoprivrede postaje i gospodarski neovisan i ostvaruje tolike prihode da može svojoj obitelji osigurati pristojnu egzistenciju. Prvi dio hrvatskoga seljaštva, koje živi oko Mostara i Trebinja, uključuje se u proces nacionalne integracije, a poslije to čine i oni s periferije Hercegovine. Jedan od velikih problema jest nedostatak prometnica. Nakon njihove izgradnje, početkom XX. stoljeća, olakšana je veza između središta i periferije, odnosno urbanoga i ruralnoga prostora. Kultura je

101 Ivan Zovko (29. 8. 1864. - 3. 3. 1900.), rodio se u Mostaru, otac Jozo, a majka Matija Čović. Nakon smrti majke otac izgubio svoje imanje, a Ivan poslan u franjevački samostan na Humac koji je zbog bolesti napustio. Odlazi u gimnaziju u Sarajevo koju napušta u IV. razredu, a onda se školuje za učitelja. Bio je u mnogim mjestima na službi: Konjicu, Ljubuškom, Varcar Vakufu, Bihaću, Sarajevu - učitelj u trgovačkoj školi, Bihaću i ponovo u Sarajevu. Pisao je u mnogim listovima pod različitim pseudonimima. Svoj život posvetio Bogu i Hrvatskoj vječnoj i vremenitoj domovini. Boljelo ga je što narod ne napreduje i nije prosvijećen. "Zagje on megju narod i poče ga buditi, bodriti i zvati na posao. On je svakog znao za se i svoje ideale predobiti. Ono malo naše narodne inteligencije obilazio je uvijek i zvao ih na posao", u: Hrvatska obrana, br. 9, Mostar, 8. 3. 1910. "Aktivan prilikom osnivanja čitaonice, Hrvatske dioničke tiskare i Osvita. Sakuplja narodno blago i tiska u knjizi Hrvatstvo u narodnim običajima u Herceg-Bosni. Šalje djecu na zanate i podupire učenike u srednjim i visokim školama. Nakon deset godina zaboravili su ga mnogi kojima je pomogao, a mnogi se stavljaju na stranu tuđinaca naših, neprijatelja koji pod hrvatskom trobojnicom i križom pridobivaju naš narod za tuđinsku misao u našoj hrvatskoj domovini", u: Hrvatska obrana, br. 9, Mostar, 8. 3. 1910. (Aludiraju na HKU, opaska T. Z.)

102 Ante Jukić, rođen 21. veljače 1873. u Donjoj Tuzli, a umro 23. svibnja 1906. u Mostaru. Kao učitelj radio u Trebinju, Žepču i Mostaru. Pisao pod pseudonimom Veljko Obradov. Urednik Učiteljske zore i Učiteljskog vjesnika i izdavao kalendar Hrvoje. Vidi: "Ante Jukić", Znameniti i zaslužni Hrvati te pomena vrijedna lica u hrvatskoj povijesti od 925.-1925., (ur. Emilij Laszowski), Zagreb, 1925., str. 122; "Ante Jukić", u: Osvit, br. 40, Mostar, 26. svibnja 1906. Naslovna strana uokvirena crnim florom, životni put i sahrana Ante Jukića. 
stvorena na temeljima građanske, koja nije bila u sukobu sa selom. Selo je dalo hrvatski gradski živalj budući da je prije u Mostaru bilo veoma malo Hrvata, zbog razloga koje smo prije naveli. Hrvatsko se građanstvo moralo oslanjati na seljaka jer nije moglo parirati brojnijem srpskom i muslimanskom građanstvu. Da je seljak uključen u proces nacionalne integracije, svjedoče nam i događaji koji nisu vezani za različite zabave pjevačkih društava i čitaonica. Prilikom vjerskih blagdana dolazi narod pod hrvatskom trobojnicom i vrpcama na grudima pokazujući svoju vjersku opredijeljenost i nacionalnu svijest. Početak ovoga procesa možemo označiti 1903. godinom kada su hrvatski seljaci iz Ravna poslali pravila za čitaonicu na odobrenje Zemaljskoj vladi. Masovnije uključivanje hrvatskoga seljaka u rad Trebižata u Ljubuškom dat će društvu zamah i kompenzirati nedostatak građanske klase kod Hrvata. Osnivanje hrvatskih seljačkih zadruga od 1906. godine i njihov rad na poboljšanju materijalnoga stanja seljaka omogućit će bolji položaj seljaka u društvu. Drugi bitan događaj je stvaranje hrvatske masovne narodne organizacije $H N Z$ 1907. godine $\mathrm{u}$ kojoj su hrvatski seljaci činili većinu.

U prethodnim fazama procesa hrvatske nacionalne integracije u Hercegovini pažnja je bila usmjerena na čitaonice i pjevačka društva. Sada je u žiži interesa preporoditelja kako popraviti položaj seljaka, obrtnika, zanatlija i radnika, koji su većina unutar hrvatskoga naroda. Uz ovaj gospodarski položaj važan je i prosvjetni razvoj kako bi se osiguralo dovoljno trgovaca, obrtnika, zanatlija i radnika, ali i onih koji su išli na sveučilište i koji su trebali predvoditi narod. Pitanje gospodarskoga i prosvjetnoga napretka Hrvata u Hercegovini postaje dominantno i sva pažnja s čitaonica i društava usmjerena je na osnivanje Hrvatskih seljačkih zadruga, podružnica Napretka i pripomoćnih društava za školovanje omladine.

Uviđajući da je vrijeme osnutka čitaonica i pjevačkih društava samo prva etapa u organiziranju i okupljanju oko hrvatske ideje, list sve više pažnje posvećuje gospodarskim udruženjima. Materijalni preporod, kao uvjet za ostvarenje svoga cilja, prisutan je kod svih naroda, a tako i kod Hrvata. "Mi se brinemo, da budimo narodna čuvstva u narodu pjesmom i čitanjem, oduševljujemo ih za sve što je hrvatsko, a ne brinemo se, kako oni materijalno stoje i kraj lošeg gospodarskog stanja ima li on kada oduševljati se za ta čuvstva! Imamo lijepih prilika za to. Dok oni, koji mogu, traže zabava, dotle narod vapi za hljebom, a kad bi imao hljeba, tad bi on radio. Čitaonice mi shvatismo sasma (sasvim op. T. Z.) jednostavno, a glavni cilj, da uzgojimo i shodnim načinom, da narod materijalno podignemo, to mimoidjosmo." ${ }^{103}$ Osnovna dužnost je mate- 
rijalno uzdizanje naroda, a onda je lako ostvariti cilj kada postoje sredstva za to. Uz čitaonice je potrebno osnivati gospodarska udruženja koja trebaju biti na pomoć svojim članovima. Naredni brojevi Osvita donose kako se osnivaju Hrvatske seljačke zadruge i njihova pravila. Cilj je bio ubrzati njihovo osnivanje te na taj način pomoći hrvatskom seljaku. ${ }^{104}$ Drugo važno polje je prosvjeta i njezin razvoj kako bi se omogućilo da kroza škole što više hrvatskoga naroda podigne razinu svoga obrazovanja. Pozdravljaju osnivanje Društva hrvatskih književnika u Zagrebu. ${ }^{105}$ Briga za hrvatskoga seljaka je stalna i uviđa se njegovo nepovoljno materijalno stanje koje se nastoji kroz različite aktivnosti popraviti, a jedna od takvih je stalno naglašavanje potrebe osnivanja seljačkih zadruga. ${ }^{106}$ Tisak u Hercegovini odigrao je veliku ulogu u širenju preporodne ideje. U Osvitu br. 101, od 24. prosinca 1902., izišao je tekst Naše sanje - Pismo prijatelju, autor se potpisuje kao Stari borac: "...Uza sve sgode i nesgode Glas. Herc. Stajao je vazda na braniku prava, pa ako je i bilo časova, kada su se razni njegovi protivnici radovali, da će podleći, držao se je i živio i slavno prestao. Ali klonuo nikada nije, ostao je vjeran svomu načelu; smjelo i odlučno dizao svoj glas za sreću otačbine, da ga dušmani nisu mogli smesti; služio je uzvišenoj ideji Hrvatstva, koju nitko više ne izčupa iz srdca naroda. A Osvit je njegov nasljednik! - Pet punih godina stoji naš Osvit na braniku narodna časti i ponosa, narodnog jedinstva i sreće, stalno ide za svojim programom, visoko diže barjak Hrvatstva i dizat će još, ako Bog da." Ovaj tekst pozdravilo je i uredništvo lista jer on sadržava programska načela Osvita.

U Osvitu je prikazana knjiga Ivana Zovke Hrvatstvo u narodnoj predaji i običajima po Herceg-Bosni ${ }^{107}$ u kojoj je autor sabrao narodno blago i običaje, obilazio sela i sačuvao narodno blago ističući njegovu važnost za narod. Ova je knjiga žestoko napadnuta od srpske strane jer nije odgovarala Vukovom velikosrpskom projektu, Srbi svi i svuda, koji negira Hrvate štokavce. Propagiranjem narodne ideje Osvit je nastojao da ona bude stalno prisutna u listu, a preko njega i među onima koji čitaju i razgovaraju o tim temama. Stalno se naglašava važnost čitaonica i pjevačkih društava u promicanju naših narodnih interesa i razvitku hrvatske misli. Ugledaju se u Dalmaciju gdje su čitaonice odigrale veliku ulogu u pobjedi narodnjaka i u njima budile povijesne uspomene, jačale ponos i čeličile volju za Hrvatstvo. Svi vodeći ljudi, učitelji, profesori, odvjetnici i

104 "Narodno gospodarstvo", u: Osvit, br. 88, Mostar, 14. 11. 1900.

105 "Na oltar hrvatske prosvjete", u: Osvit, br. 92, Mostar, 23. 11. 1900.

106 "Pomozimo seljaku", u: Osvit, br. 97, Mostar, 15. 12. 1900.

107 "Iz naroda za narod", u: Osvit, br. 20, Mostar, 8. 3. 1899. 
liječnici, trebaju raditi na osnivanju čitaonica i pjevačkih društava. Pismeni u čitaonicama trebaju čitati i objašnjavati nepismenima. Svako mjesto gdje žive Hrvati treba osnovati čitaonicu i pjevačko društvo. ${ }^{108}$ Ovaj proces osnivanja i razvoja čitaonica i društava imao je svojih uzleta, ali i padova. Kada bi splasnuo entuzijazam i zavladao nemar, dolazilo bi do zaostajanja u radu društva. Trebalo je otkloniti malodušnost i trulež unutar društava i krenuti naprijed. ${ }^{109}$ Kako bi osigurali potreban zanatski kadar, trebalo je poticati namještanje hrvatskih naučnika u Mostaru, Zagrebu i Sarajevu. Ova društva treba ustrojiti po uzoru na čitaonice i pjevačka društva koja trebaju osigurati potreban kadar za zanate koji su bitna grana gospodarskoga napretka Hrvata u Herceg-Bosni. ${ }^{110}$

Prigodom različitih proslava u Dalmaciji Glas Hercegovca i Osvit donose izvješća o proslavama, a mostarski Hrvati na njima uzimaju aktivan udjel. ${ }^{111}$

Proces hrvatske nacionalne integracije širi se iz Hercegovine prema Bosni pa su ti procesi u Bosni s izvjesnim kašnjenjem u odnosu na Hercegovinu. ${ }^{112}$ Da se proces nacionalne integracije širi iz Hercegovine prema Bosni, slažu se gotovo svi autori koji su obrađivali ovu problematiku. U izvješću visokih austro-ugarskih službenika uočava se razlika između procesa integracije kod hercegovačkih i bosanskih Hrvata. Ova izvješća odnose se na manifestacije hrvatskoga karaktera u Hrvatskoj. Na tim manifestacijama puno su zastupljeniji Hrvati iz Hercegovine nego

108 "Što radimo", u: Osvit, br. 73, Mostar, 9. 9. 1899.

109 "Naše rane", u: Osvit, br. 80, Mostar, 4. 10. 1899.

110 "Zanatom umanjujmo biedu narodnu", u: Osvit, br. 83, Mostar, 14. 10. 1899.

111 "Hrvatska neretvanska čitaonica u Metkovićima", u: Osvit, br. 8, Mostar, 25. 1. 1899., str. 5.

112 Zoran Grijak, "Analiza identitetskih odrednica bosanskih i hercegovačkih Hrvata u austro-ugarskom razdoblju", u: Hum i Hercegovina kroz povijest, Zbornik radova s međunarodnog znanstvenog skupa održanog u Mostaru 5. i 6. studenoga 2009., Knjiga II., Hrvatski institut za povijest, Zagreb, 2011., str. 122-129. Opširan opis priprema i otkrivanja spomenika fra Andriji Kačiću Miošiću u Glasu Hercegovca koji je toj manifestaciji dao veliki prostor. "Kačićev spomenik", u: Glas Hercegovca, br. 28, Mostar, 16. 7. 1890.; "Za otkriće Kačićeva spomenika", u: Glas Hercegovca, br. 29, Mostar, 23. 7. 1890.; "Dviestogodišnjica", u: Glas Hercegovca, br. 36, Mostar, 23. 8. 1890.; "O. Andrija Kačić Miošić", "HYMNA", "Predaja Kačićeva spomenika Makarskoj Obćini", u: Glas Hercegovca, br. 37, Mostar, 27. 8. 1890.; "Slavlje u Makarskoj", "Slava Kačiću", u: Glas Hercegovca, br. 38, Mostar, 30. 8. 1890. i nastavak u br. 39. od 3. 9. 1890.; "Slavlje u Makarskoj", u: Glas Hercegovca, br. 40, Mostar, 6. 9. 1890.; "Slavlje u Makarskoj", u: Glas Hercegovca, br. 41, Mostar, 10. 9. 1890. 
oni iz Bosne. Zemaljski poglavar za Bosnu i Hercegovinu Johann von Appel 20. rujna 1890. poslao je izvješće ministru B. Kállayu u kojemu ga izvješćuje o učešću Hrvata iz Hercegovine prilikom otkrivanja spomenika fra Andriji Kačiću Miošiću 26. kolovoza 1890. u Makarskoj. Od 128 hercegovačkih Hrvata samo su još dva franjevca iz Sarajeva koji su poslani kako franjevačka provincija Bosna Srebrena ne bi ostala bez svojih predstavnika na ovoj svečanosti u Makarskoj. Navodi i da su hrvatski ekstremisti došli u sukob s članovima Narodne stranke koju vodi Miho Klaić. Posebno naglašava da je biskup fra Paškal Buconjić naklonjen hrvatskim ekstremistima. Vlast je u biskupu Buconjiću gledala nacionalno svjesna Hrvata, a to je bilo suprotno njezinoj politici, koja je uz nastojanje Benjamina Kállaya propagirala bošnjaštvo i pokušavala ograničiti nacionalne pokrete Hrvata i Srba. U Mostaru je uhićena grupa mladića koja je nosila hrvatske trobojnice 1887. godine i među njima je bio biskupov bratić. Biskup je prosvjedovao zbog ovoga čina vlasti napominjući da je Srbima dopustila uporabu nacionalnih simbola, a Hrvate zbog istih uhićuje. Prosvjeduje što Monarhija oduzima pravo da se katolici nazivaju Hrvatima, a srpsko-pravoslavnim to dopuštaju od 1887. godine i oni su to uspjeli dobiti kao vjersko ime. Biskup Buconjić je zbog svoga zalaganja za starocrkvenoslavensku liturgiju i uporabu glagoljice došao u sukob s vlasti koja je u tom činu vidjela povezivanje s hrvatskim zemljama. Obilježavanje raznih godišnjica povijesnih ličnosti iz Hrvatske nije odgovaralo vlastima koje su i to smatrale povezivanjem s hrvatskim zemljama. Jedna od takvih prilika jest slavljenje svete mise za Hrvoja Vukčića Hrvatinića 14. kolovoza 1904. koju su u Mostaru služila trojica dalmatinskih svećenika. Svi ovi događaji su po mišljenju vlasti bili u funkciji nacionalnoga ujedinjenja hrvatskih zemalja za što se zalaže biskup Buconjić. U očima Beča i Rima biskup je poznat kao nacionalno usijana glava, a to je odraz visoke hrvatske nacionalne svijesti koja je u Hercegovini znatno višoj razini nego u Bosni krajem XIX. stoljeća. ${ }^{113}$

Razdoblje znanstvene propagande u Hercegovini traje od 40-ih godina XIX. stoljeća do otvaranja prvih pučkih katoličkih škola, Bratovštine sv. Antuna Padovanskoga i tiskare. Razdoblje nacionalne agitacije traje od 1872. do 1903. godine i razdoblje masovnoga pokreta od 1903. do 1914. godine. Možda bismo mogli govoriti i o jednom duljem prijelaznom razdoblju iz znanstvene propagande u nacionalnu agitaciju (od 70-ih do 80-ih godina XIX. stoljeća). Razdoblje nacionalne agitacije u masovni nacionalni pokret određeno je početkom XX. stoljeća. Tada se

113 Zoran Grijak, Politička djelatnost vrhbosanskog nadbiskupa Josipa Stadlera, Dom i svijet, Zagreb, 2001., str. 157-177. 
u Hercegovini, uz hrvatsko građanstvo koje je sada u Mostaru, Trebinju, Ljubuškom, Konjicu, Nevesinju, Čapljini, Stocu i Širokom Brijegu te ostalim varošicama, aktivno uključuje i hrvatski seljak. Proces nacionalne integracije uhvatio je korijen i na selu, koje se sve više uključuje $\mathrm{u}$ različite nacionalno obojene manifestacije. Boreći se protiv nepismenosti, kroz čitaonice i škole, različita društva okupljaju se i šire narodnu ideju uz pomoć franjevaca, inteligencije i građanstva. Granicu između posljednja dva razdoblja unutar procesa integracije odredili smo na osnovi aktivnoga sudjelovanja hrvatskoga seljaka u preporodnim gibanjima već na prijelazu iz XIX. u XX. stoljeće.

Nakon otvaranja željezničke pruge Mostar - Metković ova dva grada povezana su sigurnijom prometnom vezom pa tako i brojni Hrvati iz Dalmacije dolaze u Mostar i o tome šalju dopise Osvitu "...dalmatinski Hrvat prolazi kroz kršnu Hrvatsku Hercegovinu. Kao i Mije Pavlinović da vidi braću u borbi za narodni opstanak... Ponosan na Hrvate $\mathrm{u}$ Mostaru... Nema puno pretplatnika i suradnika iz Dalmacije u Osvitu. U kavanama nema hrvatskih listova. Pravi Dalmatinac."114 Osvit prati i politička zbivanja u Dalmaciji, pa u tekstu "Stranačke prilike u Dalmaciji"115 negoduje zbog bratoubilačke borbe između dalmatinskih Hrvata. Česti dopisi iz Dalmacije u Osvitu upozoravaju nas da se list čita i u susjednoj Dalmaciji. ${ }^{116}$ Nisu samo Hrvati iz Mostara odlazili u hrvatske zemlje na škole i sveučilište, bilo je i Hrvata s tih prostora koji su se školovali u Mostaru. Tako godine 1901. nalazimo da su ispit zrelosti položili na Velikoj gimnaziji u Mostaru: Niko Zvonimir, Bjlovičić iz Janjine u Dalmaciji, Zvonimir Koletić iz Đurđevca u Hrvatskoj i Rafo Merkadić iz Dubrovnika. ${ }^{17}$

Osvit se zalaže za uporabu glagoljice, što posebice raduje dalmatinske svećenike od kojih primaju i priloge za list. ${ }^{118}$ Povodom istupa hrvatskih delegata u Budimpešti, radi obrane hrvatskoga jezika, mostarsko-hrvatsko građanstvo poslalo je brzojav: "U odsutnom času, čestitajući i mi

114 "Pravi Dalmatinac", u: Osvit, br. 91, Mostar, 11. 11. 1899., str. 3-4.

115 "Stranačke prilike u Dalmaciji", u: Osvit, br. 96, Mostar, 29. 11. 1899., str. 2-3.

116 "Glas iz Dalmacije o Zovkinu Hrvatstvu u narodnoj predaji i običajima u Herceg-Bosni", u: Osvit, br. 85, Mostar, 21. 10. 1899.; "Društveno iz Krešimirova grada", u: Osvit, br. 4, Mostar, 12. 1. 1901., str. 5; "Hrvatska kruna", u: Osvit, br. 2, Mostar, 10. 1. 1907.; "Pismo iz Dalmacije", u: Osvit, br. 3, Mostar, 15. 1. 1907. "Daj te braćo, samo napred, moralna, a do potrebe i materijalne potpore naše, ne će vam uzmanjkati."

117 "Ispit zrelosti", u: Osvit, br. 48, Mostar, 22. 6. 1901., str. 2-3.

118 "Živjeli sljedbenici Grgura Ninskog!", u: Osvit, br. 21, Mostar, 20. 2. 1907., str. 2. 
Hrvati kršne Hercegovine na odlučnom stanovištu hrvatske delegacije u obrani hrvatskog jezika... Hrvati građani Mostara." 119

Don Vidoje Lekić, koji je podrijetlom iz Hercegovine, a na službi u Dalmaciji, nije zaboravio Hrvate u Hercegovini, pa u Tihaljini podiže zgradu za školu. ${ }^{120}$ Mostarski hrvatski Sokol uspostavio je prilično živu suradnju s Dalmacijom u koju organizira često izlete kao onaj na Korčuli. "...a na krasnoj obali modrog našeg Jadrana lepršale stotine naših milih trobojnica". ${ }^{21}$

Zbog duge granice i prirodne upućenosti, jedne na drugu, veza Hercegovine s Dalmacijom je bila najrazvijenija. Hrvati iz Mostara budno prate i zbivanja u ostalim hrvatskim zemljama. Tako je Hrvatsko glazbeno pjevačko društvo Hrvoje gostovalo na proslavi Kola u Zagrebu, ${ }^{122}$ a povodom proslave Vile u Varaždinu upućen je brzojav jer nije mogao biti nazočan na proslavi. ${ }^{123}$ Djelatnost Hrvata u Mostaru nije mogla ostati nezapažena ni u ravnoj Slavoniji, pa se tako javljaju dopisi "sa Drave rieke evo šaljemo braći Hrvatima na rieci Neretvi bratski glas... Dužnost "Osvita" da budi hrvatsku svijest i da se bori za hrvatstvo Herceg-Bosne, a i da probudi Hrvatsku misao..."124

Prate se i zbivanja u Istri i povodom otvaranja hrvatske gimnazije u Pazinu Osvit pod naslovom "Nova hrvatska pobjeda": "Naša hrvatska braća u Istri moraju da izdržavaju tešku borbu s talijanašima. Oni se protive svakom i kulturnom uspjehu hrvatske nam braće." ${ }^{125}$ Svaki uspjeh hrvatskoga lista i naroda u Mostaru prati se čak i u Hrvatskom braniku koji izlazi u Mitrovici, a u svome članku "Hrvatstvo u Herceg-Bosni"126 piše o mostarskom Osvitu i njegovu radu.

Obilježavajući sedam godina izlaženja Osvita donosi se kraći osvrt na događaje u tom razdoblju (Osvit, br. 58, 26. 7. 1905.) od osnutka 27. srpnja 1898. do 26. srpnja 1905., prisjećajući se događaja prije sedam godina:

119 "Brzojav", u: Osvit, br. 43, Mostar, 18. 5. 1907.

120 "Nova škola", u: Osvit, br. 42, Mostar, 16. 5. 1907.

121 "Naše sokolstvo", u: Osvit, br. 71, Mostar, 1. 8. 1907.

122 "Slavlje Kola i hrvatske pjesme u Zagrebu", u: Osvit, br. 68, Mostar, 30. 8. 1902.

123 "Hrvatski Hrvoje hrvatskoj Vili u Varaždinu", u: Osvit, br. 73, Mostar, 19. 9. 1900.

124 "Sa Drave", u: Osvit, br. 1, Mostar, 1. 1. 1899., str. 1-2.

125 "Nova hrvatska pobjeda", u: Osvit, br. 17, Mostar, 25. 2. 1899., str. 5.

126 "Hrvatstvo u Herceg-Bosni", u: Osvit, br. 41, Mostar, 20. 5. 1899., str. 2-3. Hrvatski branik (Mitrovica) pravaški list izlazio od 1893. do 1914. godine kada je zabranjen. Urednici Đuro Mihelčić, Ivo Svirčević i Nikola Dogan. 
"Toga dana izjaviše onu javno, otvoreno, bez okolišanja, da će se vazda boriti svim svojim silama za sveto pravo svoje. Tog dana označiše i sebi zadatak, koji se ima zajedničkim silama riešiti, da dovede hrvatski narod do bolje budućnosti - do ujedinjenja hrvatskog naroda, hrvatskih zemalja - što ga po Bogu i pravdi spada."127 Zadatak Osvita je bio okupiti sve snage društva pod hrvatsku zastavu i narodno hrvatsko ime. Radili su na opstanku, napretku i narodnom prosperitetu, a taj se rad morao temeljiti na moralu i narod je morao spoznati svoje pogreške i vrline. Trebalo mu je ukazati na put gospodarskoga napretka: "Tim putem - putem čisti hrvatske misli - pokročio je Osvit prvim danom, kročio je kroz sedam godina..., a proslijediti će i nadalje. Hrvatsko državno pravo je za nj ona svietla točka, ona zviezda, koja će mu biti vazda na vdiku, da ga podsjeća dužnosti njegove. Ono će i napried Osvitu biti ravnalo, koje će odredjivati našim mišljenjem, radom i nastojanjem. Prema tom uzvišenom cilju uzradit ćemo i posvetit sve sile svoje, jer odgovara probitcima i mišljenju hrvatskog naroda."128 Ovaj čvrsti stav na politici Stranke prava i glorificiranju Ante Starčevića bio je stalna odrednica pisanja Osvita. ${ }^{129}$ Posvećujući se hrvatskom narodu i tražeći uzroke njegova stanja, donosi afirmativan članak u svome uvodniku "Zašto Hrvati ne napreduju?". Traže uzroke u lijenosti i nemarnosti, lihvarima i brzopletom zaduživanju i trošenju novca na modu i luksuz. Još je jedan od uzroka koji koče napredak, a to je čaša i nerad koji su uništili veliki broj obitelji. ${ }^{130}$

Što je aneksija bila bliža, politička pitanja postaju sve više aktualna, a posebice odnos prema muslimanima i hrvatsko-srpski odnosi. Kojim smjerom treba ići hrvatska politika u Herceg-Bosni? U nekoliko nastavaka donosi se opširan pregled prošlosti kako bi se budućnost mogla graditi na načelima hrvatskoga državnog prava. Pozivaju sve one kojima je stalo do naroda da to potvrde svojim radom. Kako bi se popravio položaj naroda, pozivaju sve hrvatske domoljube na rad za narod. ${ }^{131}$

Osvit u svome uvodniku donosi tekst pod nazivom: "Ideja pobjegjuje!": "...I hrvatski narod naš, već odavna bori se za svoj opstanak... Al se je na našu sreću našlo uvijek idejalnih ljudi, koji su se odvažno i ustrajno borili za ideju preporoda i moralno uskrsnuće naroda našega... Bez borbe nema napretka, bez borbe nema ni moralne, ni materijalne slobode. I hrvatska

127 "27. srpnja 1898.", u: Osvit, br. 58, Mostar, 26. 7. 1905.

128 Isto.

129 "Slava Anti Starčeviću", u: Osvit, br. 66, Mostar, 23. 8. 1905. Polemika s Katoličkim listom oko A. Starčevića.

130 "Zašto Hrvati ne napreduju?", u: Osvit, br. 76, Mostar, 27. 9. 1905.

131 "U narod", u: Osvit, br. 2, Mostar, 5. 1. 1907. 
ideja u našoj užoj domovini, u Bosni i Hercegovini, malo se po malo preporagja. Sa zadovoljstvom opažamao, da su se svi zdraviji i trezniji elementi okupljaju danas oko te jedine spasavajuće ideje, koja i protiv svih zapreka sa strane prodire i osvaja pojedince i mase... Dosta i dosta je vremena ta ideja drijemala pod pepelom, gdje su je bile zatrpale nepovoljne povijesne prilike, al se sad pred daškom novih vremena, pomlagjena i preporogjena javlja velikim plamenom, koji prije ili kasnije mora zagrijati svenarodne elemente. Ideja, velika dakle ideja narodne hrvatske svijesti, pobijedila je i u ovim krajevima, a budemo li ju ustrajno i odvažno podupirali, ona će naskoro sve umjetne prepone savladati i dovesti narod naš do žudjene slobode. Staze su poravnane, radimo i nadajmo se, jer: Ideja pobjegjuje."132

Stalno je prisutan interes oko gospodarskoga prosperiteta i kako pomoći obrtniku, radniku i seljaku. Oni moraju napredovati kako bi popravili svoj položaj, ali i osigurali da njihova djeca idu u školu, posjećuju zabave i sijela. Da bi se razvila hrvatska narodna svijest u svim strukturama društva, moraju dati doprinos u svojim strukovnim udruženjima. ${ }^{133}$

Početkom 1908. godine obilježeno je dvadeset pet godina od prvoga broja Hercegovačkog bosiljka koji je izišao 23. rujna 1883. Ovo razdoblje, uz dva kraća prekida, bilo je prožeto borbom, odricanjem, odrastanjem, kako u tehničkom pogledu tako i na profesionalnome novinarskom pozivu. Uspio se održati kontinuitet i kod čitatelja je stvorena navika čitanja novina, što je bio veoma težak zadatak kada uzmemo u obzir koliko je bilo pismenoga naroda. Sve poteškoće na ovome putu, koji je bio neizvjestan i mukotrpan, uspješno su prebrođene zahvaljujući viziji don Frane Milićevića. On je otac hrvatskoga novinarstva u Bosni i Hercegovini, zajedno sa svojim pomagačima budio je i gajio hrvatsku svijest. "Bilo je vrijeme, kad je hrvatsko ime bilo grijeh, njegovo isticanje prekršaj. Kakove je poteškoće imao da savlada don Frano Milićević, dovoljna je slika ta, da današnje hrvatsko pjevačko društvo Hrvoje, koje postoji već preko dvadeset godina, do 1898. uzalud po skupštinskim zaključcima redovito svake godine moli vlast, da se društvu prizna u naslovu hrvatsko ime. Kako je bilo u Mostaru, tako je bilo i po ostaloj Bosni i Hercegovini. U vremenu, u kojem je hrvatsko ime bilo strašilo, izdavati i uregjivati hrvatske novine - bila je smjelost i žrtva. I ipak je išlo radilo se. U početku širi slojevi nisu toliko ni osjećali potrebu novina, i trebalo je u te slojeve prodirati. Velik posao. Radenicima na narodnoj njivi pošlo je ipak za rukom, da se narod pridigne, osvijesti, da zavoli pismenost, knjigu. Što danas imademo u tom pogledu, to imamo zahvaliti radu i trudu iz onog vremena, koje za nas u Bosni i Hercegovini 
znači doba preporoda, doba rastućeg oduševljenja- kao što je ilirski preporod, koji, naravno, ima drugo znamenovanje. U doba toga našeg preporoda stvarju se narodna pjevačka, glazbena, čitaonička društva hrvatska se nisu smijela stvarati. Domaći gragjani pojedinih mjesta okupljaju se u kolu-oduševljavaju se i žrtvuju za narodne zavode znatne svote novca. Svijest narodna se diže, daje znake o svom životu, dok se nakon dvadeset i pet godina ti znakovi života ne pojaviše širom ovih zemalja." ${ }^{134}$

Ovo je bila faza kada je narod trebalo animirati i proširiti hrvatsku svijest kroz različita društva. U narednom periodu započela je borba za gospodarsko i prosvjetno jačanje hrvatskoga naroda. Stvaranjem Hrvatske narodne zajednice, koja postaje krovna organizacija Hrvata u Bosni i Hercegovini, osigurani su preduvjeti za bolju budućnost i prosperitet naroda. Stalno izlaženje novina kao i razni problemi doveli su Osvit ${ }^{135}$ i Hrvatsku dioničku tiskaru u velike financijske probleme. Obraćaju se svojim pretplatnicima daju obavijest da Osvit prestaje izlaziti 30. lipnja 1908. Deficit Osvita je prevelik teret za Hrvatsku dioničku tiskaru i ona to više nije u stanju financirati: "Da se Hrv. dionička tiskara podigne i što bolje razvije, nužno je, da je Hrvati Herceg-Bosne naručbama što više podupru, i tako omoguće, da možda za kratko vrijeme a uz povoljnije prilike, tiskara uzmogne opet izdavati list, neophodno potreban u glavnom gradu Hercegovine."136

Uz povezivanje s Dalmacijom uviđa se potreba povezivanja Mostara s drugim centrima u Hercegovini. Tako se cestom nastoje povezati Mostar i Duvno preko Širokoga Brijega i Vranića u članku Potreba ceste, Osvit u broju 13. od 14. veljače 1900., str. 5: "Iz kotara mostarskoga je cesta od Duvna-Posušja do Mostara gotovo dograđena. Dosta neprohodno od Širokog Briga do Vranića (kod Kočerina, više jaruga i stotine vrela)... Trgovci iz Duvna uzimaju robu u Mostaru, a svoje proizvode gone u Dalmaciju te je prodaju u bescijenje."

134 "Četvrt vijeka", u: Osvit, br. 1, Mostar, 4. 1. 1908.

135 "Osvitovim prijateljima", u: Osvit, br. 64, Mostar, 4. 6. 1908. Vijest o prestanku izlaženja lista razveselila je prijatelje Osvita koji su jedva to dočekali. Mostarskim Hrvatima treba jedan list. "Mi smo Hrvati, mi trebamo da promičemo i štitimo hrvatsku misao, mi treba da hrvatski mislimo i osjećamo - mi trebamo hrvatski list... Mi ne bismo bili nikakovi Hrvati, kad bi se ustručavali ma pred kim bilo nazvati sebe Hrvatima, svoj jezik hrvatskim jezikom, svoju zemlju hrvatskom zemljom... Čista hrvatska misao budi Hrvatu vazda sveta! Bog i Hrvati! Gragjanin."

136 "Pretplatnicima i čitateljima Osvita, te dioničarima Hrv. dioničke tiskare na uvažavanje", u: Osvit, br. 69, Mostar, 20. lipnja 1908. Zadnji broj 72 izišao 1. srpnja 1908. 
Ovi dopisi govore o teškoj cestovnoj komunikaciji između središta i periferije naročito smjerom prema Zapadu, dok je ta komunikacija dolinom Neretve bila znatno lakša. O putu od Mostara do Širokoga Brijega govori i Kristofor Milas ${ }^{137}$ što je sve doživio na putu preko Blata i preko rijeke Lištice.

Željeznička veza od Metkovića do Mostara u dužini od 42,4 km puštena je u lipnju 1885. godine uz troškove od 1,700.000 forinti osiguranih preko zajma što je dan bosanskohercegovačkoj upravi iz zajedničkih aktiva. ${ }^{138}$ Mostar se povezuje željeznicom i s Bosnom. Pravac Mostar Ostrožac otvoren je u kolovozu 1888., Ostrožac - Konjic otvoren je u studenom 1889. i Konjic - Sarajevo izgradnja pruge je dovršena u kolovozu 1891. ${ }^{139}$ Budući da je Sarajevo još prije spojeno željezničkom prugom s Bosanskim Brodom, odnosno Austro-Ugarskom Monarhijom, i Mostar je tada uključen u željezničku mrežu Austro-Ugarske Monarhije.

Uspostava komunikacija između Hercegovine i Dalmacije, kao i prometnih veza unutar Hercegovine i prema Bosni dolinom Neretve označili su kraj prometne izoliranosti Hercegovine i Mostara. Austro-Ugarska Monarhija razvija prometni sustav jer je to u njezinu interesu, ali to ujedno zbližava hrvatske zemlje i ruši stoljetnu prepreku izoliranosti i udaljenosti koja je stvorena kod pučana, zbog nedostatka prometnih komunikacija. Prometne, trgovačke, kulturne, pa i političke veze se uspostavljaju i jače razvijaju od 1878. godine. Povezivanje Mostara, kao središta, s okolnim naseljima unutar Hercegovine pa i Bosne označit će gospodarsko jačanje grada kao središta Hrvata u Hercegovini i Bosni sve do početka XX. stoljeća.

\section{STANOVNIŠTVO MOSTARA U RAZDOBLJU HRVATSKE NACIONALNE INTEGRACIJE}

O broju stanovnika u Hercegovini u prvoj polovici XIX. stoljeća možemo govoriti na osnovi izvješća putopisaca koji iz Europe s različitim interesima dolaze u Hercegovinu. Naravno, njihove su brojke subjektivne i ovise o onome tko im je vodič i domaćin. Za katolike su značajne biskupske vizitacije i popis 1851. godine koji je provela osmanlijska vlast, a prave popise dočekat će tek dolaskom Austro-Ugarske Monarhi-

137 "Iz Metkovića u Mostar 1872. godine", u: Osvit, br. 26, Mostar, 23. 3. 1899.

138 Izvještaj o upravi Bosne i Hercegovine 1906. izdalo C. i Kr. Zajedničko ministarstvo financija, Zagreb, 1906., str. 508; Bosna i Hercegovina u brojkama, Hrvatska dionička tiskara, Mostar, 1911., str. 19-20.

139 Izvještaj o upravi Bosne i Hercegovine 1906. ..., str. 509. 
je. Tijekom XIX. stoljeća, nakon dolaska biskupa u grad, zaustavljena je tendencija opadanja katoličkoga pučanstva u gradu. Katolici se demografski oporavljaju tijekom druge polovice XIX. stoljeća. Promjena državne uprave 1878. godine značila je ipak korak naprijed za Hrvate koji postupno popravljaju svoj položaj koji je bio vrlo loš tijekom osmanske uprave. Progoni i iseljavanja za vrijeme osmanske uprave nisu uspjeli iskorijeniti Hrvate u gradu. O broju pučana tijekom XIX. stoljeća u Bosni i Hercegovini veoma je teško govoriti jer za vrijeme osmanske uprave samo jedan popis je služben, i to onaj 1851. godine. Ostalo su procjene koje su rađene s manje ili više točnosti.

Prema službenom popisu 1851. godine bilo je samo 1,077.956 stanovnika $^{140}$ zajedno s Novopazarskim Sandžakom, a kada se uzme samo današnji teritorij Bosne i Hercegovine, onda je broj 916.000 pučana. ${ }^{141}$ Dolaskom Austro-Ugarske Monarhije urađena su četiri popisa, daleko ozbiljnije i temeljitije nego je to činila osmanlijska vlast.

Tabela br. 1. Popisi Austro-Ugarske Monarhije ${ }^{142}$

\begin{tabular}{|l|l|l|l|l|}
\hline \multirow{2}{*}{ Godina } & \multirow{2}{*}{$\begin{array}{l}\text { Broj civilnoga } \\
\text { stanovništva }\end{array}$} & \multicolumn{2}{|l|}{$\begin{array}{l}\text { Čitavi prirast civilnoga žiteljstva } \\
\text { od zadnjega popisa }\end{array}$} & $\begin{array}{l}\text { Prosječni godišnji po- } \\
\text { rast od zadnjega popisa } \\
\text { u postotcima }\end{array}$ \\
\cline { 3 - 5 } & apsolutno & u postotcima & \\
\hline 1879. & $1,158.164$ & - & - & - \\
\hline 1885. & $1,336.091$ & 177.927 & 15.36 & 2.56 \\
\hline 1895. & $1,568.092$ & 232.001 & 17.36 & 1.74 \\
\hline 1910. & $1,898.044$ & 329.952 & 21.04 & 1.40 \\
\hline
\end{tabular}

140 ĐorĐe Pejanović, Stanovništvo Bosne i Hercegovine, Srpska akademija nauka, Odeljenje društvenih nauka, knj. 12, Beograd, 1955., tabela 1.

141 Isto, tabela 2.

142 Rezultati popisa žiteljstva u Bosni i Hercegovini od 10. 10. 1910., Sarajevo, 1912., str. XX. 
Tabela br. 2. Popisi po vjeroispovijesti u Bosni i Hercegovini 1879.-1910.

\begin{tabular}{|l|l|l|l|l|}
\hline $\begin{array}{l}\text { Vrijeme } \\
\text { popisa }\end{array}$ & $\begin{array}{l}\text { Broj } \\
\text { katolika }\end{array}$ & $\begin{array}{l}\text { Broj } \\
\text { muslimana }\end{array}$ & Broj pravoslavnih & $\begin{array}{l}\text { Sveukupno } \\
\text { pučanstvo }\end{array}$ \\
\hline $15.6 .1879 .{ }^{143}$ & 209.391 & 448.613 & 496.761 & $1,158.164$ \\
\hline $1.5 .1885 . .^{144}$ & 265.788 & 492.710 & 571.250 & $1,336.091$ \\
\hline $22.4 .1895 .{ }^{145}$ & 334.142 & 548.632 & 673.246 & $1,568.092$ \\
\hline $10.10 .1910 .{ }^{146}$ & 434.061 & 612.137 & 825.418 & $1,898.044$ \\
\hline
\end{tabular}

Katoličko stanovništvo u ovome razdoblju (1879.-1912.) poraslo je s 18,1 $\%$ na 22,9 \% u ukupnoj strukturi pučanstva Bosne i Hercegovine. Od ukupno 55 kotara katolici su u pretežnoj većini u 12 kotara, a u tri kotara (Bugojno, Brčko i Grdačac) gotovo u jednakom omjeru zastupljene su sve tri vjeroispovijesti.

Katolici više od 50 \% ukupnoga pučanstva imaju u Ljubuškom 92,69 \%, Duvnu (Županjac) 86,94 \%, Mostaru (seoska općina) 74,22 \%, Fojnici $63,19 \%$, Prozoru $61,87 \%$ i Livnu 52,94 \%, a Stolac s $46,21 \%$ je blizu te brojke. ${ }^{147}$

U Mostaru broj stanovnika prema popisima 1895. i 1910. iznosio je: ${ }^{148}$

Tabela br. 3. Popisi u Okružju Mostarskom

\begin{tabular}{|c|c|c|c|c|}
\hline \multirow[t]{2}{*}{ POLITIČKI KOTARI } & \multicolumn{2}{|c|}{ Prisutno civilno žiteljstvo } & \multicolumn{2}{|l|}{ Prirast } \\
\hline & 1895. & 1910. & apsolutno & $\%$ \\
\hline Mostar, gradski kotar & 14.370 & 16.392 & 2.022 & 14,7 \\
\hline Mostar, seoski kotar & 39.081 & 50.226 & 11.145 & 28,52 \\
\hline Okružje Mostarsko & 219.511 & 267.038 & 47.527 & 21,65 \\
\hline
\end{tabular}

143 Štatistika miesta i pučanstva Bosne i Hercegovine, Službeno izdanje, Sarajevo, 1880., str. 4.

144 Štatistika mjesta $i$ žiteljstva Bosne $i$ Hercegovine po popisu naroda od 1. maja 1885., Službeno izdanje, Sarajevo, 1886., Glavni pregled.

145 Popis žiteljstva u Bosni i Hercegovini 1895., Sarajevo, 1896., str. LVII.-LIX.

146 Rezultati popisa žiteljstva u Bosni i Hercegovini od 10. 10. 1910., Sarajevo, 1912., str. LIII.

147 Isto, str. XLIX.

148 Glavni rezultati popisa žiteljstva u Bosni i Hercegovini od 22. 4. 1895., Sarajevo, 1896., str. 490-500; Rezultati popisa žiteljstva u Bosni i Hercegovini od 10. 10. 1910., Sarajevo, 1912., str. XXII. 
U Okružju Mostarskom konfesionalni sastav pučanstva 1910. godine ${ }^{149}$ bio je:

Tabela br. 4. Konfesionalni sastav pučanstva 1910. godine

\begin{tabular}{|l|l|l|l|}
\hline OKRUŽJE & Pravoslavni & Muslimani & Rimokatolici \\
\hline \multirow{2}{*}{$\begin{array}{l}\text { apsolutno } \\
\text { Mostar }\end{array}$} & 90.780 & 63.666 & 112.020 \\
\cline { 2 - 4 } & $34,00 \%$ & $23,84 \%$ & $41,95 \%$ \\
\hline
\end{tabular}

Ostalo stanovništvo čine grkokatolici (29), sefardički židovi (iz Španjolske doseljeni o. p. T. Z.) (96), ostali židovi (310), evangelici (146), što ukupno čini u Okružju Mostarskom 267.038 pučana.

Kada gledamo odnos između grada i sela, u Bosni i Hercegovini je 1910. godine u gradovima živjelo 278.203 stanovnika sa sljedećim sastavom vjeroispovijesti:

Tabela br. 5. Gradsko stanovništvo u $\mathrm{BiH}$ 1910. godine

\begin{tabular}{|l|l|l|}
\hline Muslimani & 141.225 & $50,76 \%$ \\
\hline Katolici & 68.113 & $24,49 \%$ \\
\hline Pravoslavni & 55.416 & $19,92 \%$ \\
\hline Sefardički židovi & 7.843 & $2,82 \%$ \\
\hline Ostali židovi & 3.272 & $1,18 \%$ \\
\hline Evangelici & 1.641 & $0,59 \%$ \\
\hline Grkokatolici & 619 & $0,22 \%$ \\
\hline Ostali & 74 & $0,02 \%{ }^{150}$ \\
\hline
\end{tabular}

Muslimani su imali apsolutnu većinu u 43 grada, a katolici u 5 i pravoslavni u samo jednom gradu. U 17 gradova nije nitko imao natpolovičnu većinu. ${ }^{151} \mathrm{Da}$ bismo mogli realnije sagledati pučanstvo Mostara,

149 Rezultati popisa žiteljstva u Bosni i Hercegovini od 10. 10. 1910., Sarajevo, 1912., str. XLVIII.

150 Isto, str. XLIX.

151 Glavni rezultati popisa žiteljstva u BiH od 22. 4. 1895., Sarajevo, 1896., str. 490 500; Rezultati popisa žiteljstva u BiH od 10. 10. 1910., Sarajevo, 1912., str. 356365. 
moramo usporediti gradsku općinu Mostar i seoski kotar - Mostar. Usporedit ćemo popise iz 1895. i 1910. godine. ${ }^{152}$

Tabela br. 6. Popisi 1895. i 1910. godine u Mostaru, seoski kotar i gradska općina

\begin{tabular}{|l|l|l|l|l|l|}
\hline Politička općina & Godina popisa & Katolici & Muslimani & Pravoslavni & Ostali \\
\hline $\begin{array}{l}\text { Mostar, gradska } \\
\text { općina }\end{array}$ & 1895. & 3.353 & 6.946 & 3.877 & 194 \\
\cline { 2 - 6 } & 1910. & 4.307 & 7.212 & 4.518 & 355 \\
\hline $\begin{array}{l}\text { Mostar, seoski } \\
\text { kotar }\end{array}$ & 1895. & 28.409 & 6.250 & 4.422 & - \\
\cline { 2 - 6 } & 1910. & 37.276 & 7.023 & 5.925 & 4 \\
\hline
\end{tabular}

U gradskoj općini Mostar bilo je 1895. ukupno 14.370 stanovnika, a 1910. godine 16.392. U seoskom kotaru Mostar 1895. godine bilo je 39.081, a 1910. godine 50.226 stanovnika. ${ }^{153}$

Velike razlike između gradske općine i seoskoga kotara imaju svoj uzrok u višestoljetnoj osmanskoj upravi koja je zabranjivala život katolicima u blizini muslimana, a posljednja takva zabrana bila je 1840. godine. Katolici su jedino mogli živjeti dalje od urbane jezgre koju naseljavaju muslimani, pa se oni naseljavaju uz rubne prostore Mostara koji su nacionalno homogeni. Sam grad Mostar nalazi se na rubu najhomogenijega hrvatskog etničkog prostora i kao posljedica toga on sve više poprima hrvatsko obilježje.

\section{HRVATSKO GLAZBENO-PJEVAČKO DRUŠTVO HRVOJE}

Hrvati su u Mostaru već dulje vrijeme pokušavali osnovati svoje pjevačko društvo, ali im okolnosti nisu išle na ruku za vrijeme Osmanskoga Carstva, a ni nakon dolaska Austro-Ugarske Monarhije. Kako to nije išlo lagano, oni su pod okriljem crkve pjevali i vježbali kao crkveni zbor te čekali neko bolje vrijeme. Trebalo je proći čitavo desetljeće da bi uspjeli osnovati pjevačko društvo koje je nosilo neutralno narodno ime i nije se smjelo baviti politikom. Iako je ime bilo narodno, svi su u Mostaru veoma dobro znali o čemu se radi i strpljivo čekali priliku da postane hrvatsko, a za to je trebalo čekati još jedno desetljeće. Sve ovo nije obe-

152 Glavni rezultati popisa žiteljstva u BiH od 22. 4. 1895., Sarajevo, 1896., str. 490500; Rezultati popisa žiteljstva u BiH od 10. 10. 1910., Sarajevo, 1912., str. 356365.

153 Glavni rezultati popisa žiteljstva u BiH od 22. 4. 1895., Sarajevo, 1896., str. 490500; Rezultati popisa žiteljstva u BiH od 10. 10. 1910., Sarajevo, 1912., str. 356-365 i 490-500. 
shrabrilo članove, nego im je naprotiv dalo još veću snagu da izdrže i izrastu u vodeće hrvatsko društvo u Hercegovini. Zahvaljujući dolasku biskupa u grad, Bratimstvu sv. Ante, tiskari i njezinoj izdavačkoj djelatnosti, čitaonicama, Narodnom pjevačkom društvu i novinama koje su izlazile, Mostar je postao središte procesa nacionalne integracije u drugoj polovici XIX. stoljeća. Prateći što rade Hrvati u Dalmaciji, i u Mostaru su pokušali osnovati jedno društvo, ali to nije bilo po volji osmanskoj vlasti koja je u njemu vidjela opasnost. Vlast nije htjela udovoljiti niti jednom zahtjevu bojeći se novih, nakon osnivanja Bratimstva sv. Antuna Padovanskog 1872. godine, kao prve organizirane građanske udruge, sa zadatkom brige o katolicima. Kako bi okupili hrvatsku mladež, zatraženo je da se osnuje Hrvatsko pjevačko glazbeno društvo Kosača 1873. godine. Ovo nije odobreno, a Hrvati u Mostaru su potajno djelovali kao crkveni zbor sve do kraja osmanske vlasti. Kada je došla nova katolička vlast i ona je odbila potvrditi Hrvatsko pjevačko društvo Kosača s obrazloženjem da ne može dopustiti društvo koje ima samo jednu vjeroispovijest. Kako se Austro-Ugarska Monarhija odnosi prema Hrvatima u Mostaru, svjedoči jedna zgoda koju je ispričao Marko Šešelj, a zabilježio don Mate Nuić. Vlast je zatvorila trideset najistaknutijih Hrvata u Mostaru samo zato što su se prilikom crkvene proslave zakitili hrvatskom trobojnicom. Ovakav pristup nije bio usamljen i on je bio odraz politike Austro-Ugarske Monarhije prema Hrvatima u prvom desetljeću njihove uprave. Hrvati iz Mostara ponovo traže dopuštenje za osnivanje Hrvatskog pjevačkog društva Višević i naravno da je odgovor bio negativan. Ni ovo nije moglo zaustaviti mostarske Hrvate koji okupljaju sve nacionalno svjesne građane oko crkvenoga zbora i čekaju pogodan trenutak da javno mogu istupiti. ${ }^{154}$ Nastavljaju se pokušaji oko osnivanja društva. Krajem 1888. godine Austro-Ugarska Monarhija konačno daje uvjetnu dozvolu, ali da se iz naziva ispusti hrvatsko obilježje.

Nakon što je Zemaljska vlada potvrdila 10. studenoga 1888. pravila $\mathrm{Na-}$ rodnog pjevačkog družtva u Mostaru, ${ }^{155}$ saziva se Skupština 8. prosinca

154 Don Mate Nuić, "Pedeset godina rada i života H. P. D. Hrvoje", u: Spomenici o 50-godišnjici Hrvatskog pjevačkog društva Hrvoje u Mostaru, Mostar, 1938., str. 8-9; Hrvatsko glazbeno-pjevačko društvo Hrvoje Mostar, 120. obljetnica, Mostar, 2008., str. 9-10.

155 Arhiv Bosne i Hercegovine Sarajevo (dalje: ABiH Sarajevo), Napretkova kulturno-historijska zbirka, 1139/IV, Pravila za narodno pjevačko družtvo u Mostaru usvojena 10. kolovoza 1888., odbornik Ivan Smoljan, odbornik Niko Fišić, podnačelnik Blažko Zelenika i odbornik, predsjednik fra Augustin Zubac potpisnici, a Zemaljska vlada 10. 11. 1888. odobrila br. 1373/res. Na osnovi otpisa zajedničkoga Ministarstva od 3. 11. 1888., br. 783. B. H., Za poglavicu Zemaljske Vlade administrativni upravitelj S A U E R W A L D. 
1888. na kojoj su bila 42 člana uz nazočnost kotarskoga predstojnika gospodina Foglara. Tom prilikom izabrani su za Odbor članovi: predsjednik O. Augustin Zubac, bisk. tajnik, za tajnika Anto Butigan, za zborovođu F. Prochaska, ${ }^{156}$ vjeroučitelj i zamjenik zborovođe O. Božo Ostojić, blagajnik Ivan Bašadur, arhivar (čuvar pismohrane) Jure Smoljan, odbornici: Nikola Fišić, Blažko Zelenika, Ivan Smoljan, Šimun Ćorić, Mijat Merdžo, Ilija Ćuk, Ivan Dika, Mate Čule, Pero Kurtaga, Šimun Milićević. Za potpredsjednika izabran je Blažko Zelenika koji je ujedno i podnačelnik Mostara. ${ }^{157}$ Narodno pjevačko družtvo u Mostaru imalo je za svrhu njegovanje glazbe, pjevanja i instrumentalne glazbe kao i unapređenje društvenoga života isključujući svaki politički značaj. Sudjelovanje društva vidljivo je na zabavama, besjedama, predstavama, svečanostima, vjerskim službama i dobrotvornim manifestacijama. Društvo je imalo izvršavajuće (stalne op. T. Z.), podupiruće i počasne članove koji su mogli biti pripadnici Bosne i Hercegovine i Austro-Ugarske Monarhije. ${ }^{158} \mathrm{Ni}$ u jednom od 46 odredbi pravilnika nije spomenuto nacionalno ime niti nacionalnost članova društva zbog politike Austro-Ugarske Monarhije koja je to izričito zabranjivala. ${ }^{59}$ Sada je bilo vidliivo koliko je društvo, djelujući u ilegali

156 ABiH Sarajevo, Zemaljska vlada za Bosnu i Hercegovinu Sarajevo, 1 (ZVS 1), br. 180888-V-3/1916. š. 39-348/5, A. Prochaska je zborovođa do dolaska Vinka Šubira iz Zagreba 23. 11. 1889.

157 "Narodno pjevačko družtvo u Mostaru", u: Glas Hercegovca, br. 48, Mostar, 19. 12. 1888. (u prethodnim brojevima stoji društvo, a u ovom broju družtvo).

158 ABiH Sarajevo, Napretkova kulturno-historijska zbirka, 1139/IV, Pravila za narodno pjevačko družtvo u Mostaru usvojena 10. kolovoza 1888.

159 Politika Monarhije prema nacionalnom pitanju u Bosni i Hercegovini u prvom desetljeću njezine nazočnosti bila je protiv hrvatske i srpske narodne ideje, jer su oni (madžari) smatrali to svojom interesnom sferom pozivajući se da je još od 1138. godine Rama u ugarskoj kraljevskoj tituli i pripada kruni Sv. Stjepana. Budući da su ministri financija iz ugarskog dijela Monarhije, oni su i provodili takvu politiku. Zajednički ministar financija Benjamin Kállay u razdoblju 1882.1903. provodio je takvu politiku i nastojao je dovesti lojalan činovnički kadar iz Monarhije koji će biti okosnica nove uprave. Strateški položaj Bosne i Hercegovine za dalji prodor na istok bio je važan za Monarhiju. Zabranio je svaku manifestaciju hrvatstva i srpstva kao i njihova imena, grba i zastave. Nastojao je kulturno i gospodarski izolirati Bosnu i Hercegovinu od susjednih zemalja. Nastojao je nametnuti novu bosansku naciju bošnjaštvo s tri vjeroispovijesti. On je nacionalno pitanje vidio u granicama Bosne i Hercegovine i okvirima bosanske nacije. Brojni muslimani su ga podržavali u ovoj ideji, a posebice Mehmed-beg Kapetanović - Ljubušak i Safvet-beg Bašagić. Pred kraj stoljeća postalo je jasno da ovo nije moglo uspjeti i postupno se dopušta uporaba hrvatskoga i srpskoga imena. Nakon smrti Kállaya ova politika je doživjela neuspjeh pred nacionalnim pokretom Hrvata i Srba. Vidi: L. ĐAKović, Političke organizacije bosanskohercegovačkih katolika Hrvata, str. 148-151. 
kao crkveni zbor, učinilo na podizanju pjevačke razine i razvoju narodne misli. Nepoznati autor iz Sarajeva, ushićen zbog osnivanja društva, uputio je pjesmu:

Prvi biste i prvi stupiste

Na poprište kao pobornici

Kao pravi uzorznačajevi.

Stijeg trobojni slavno razviste

I preslavno ime pradjedova

Na visinu pravu postaviste. ${ }^{160}$

Prilikom organiziranja prve zabave, 29. studenog 1888., ${ }^{161}$ u slavu 40godišnjice vladanja Franje Josipa I. bilo je oko 150 osoba iz Mostara "... priličan broj pridošlo iz Metkovića i iz drugih mjesta, a naosob sa selah; koji su ujedno sa svim prisutnim, u podpunom zadovoljstvu ostali, i javno očitovali, Bože daj da što prije opet bude slična zabava, da se moć budemo nauživati ovog plemenitog veselja za kojim su naši djedi čeznuli". ${ }^{162}$ Dajući komentar o zabavi Glas Hercegovca navodi: "Mi se radujemo ovom mladom Narodnom pjevačkom družtvu na tom lijepom prokušanju, koji su znali tako krasno i s prvim pokušajem steći lijepo ime kod svih slušatelja."163 Posebno pohvaljuje hrvatsku mladež i

160 M. Nuić,"Pedeset godina rada i života H. P. D. Hrvoje", str. 11; Hrvatsko glazbeno-pjevačko društvo Hrvoje Mostar 120. obljetnica, Mostar, 2008., str. 11.

161 "U slavu 40 godišnjice", u: Glas Hercegovca, br. 45, Mostar, 28. 11. 1888.: "U slavu četrdesetgodišnjice vladanja $\mathrm{Nj}$. Veličanstva cara i kralja Franje Josipa I. i desetgodišnjice zaposjednuća Bosne i Hercegovine, priredjuju gradjani grada Mostara zabavu dne. 29. studenoga 1888. I. dio. Graničari, Igrokaz u 3. čina od Freudenreicha. II. dio. Pjesme i krasloslovje 1 pjesma hrvatsko pjev. savezu, od Iv. Pl. Zajca, 2. Udesu mome od N. Strossa. 3. Braća. Od Preradovića; 4. Uboj uboj, od Iv. Pl. Zajca. 5. Majka od H. Budalića. 6. Pozdrav domovini; od N. Strossa. Čisti prihod namijenjen za ustanovljenje zaklade narodnog pjevačkog družtva. Ulaznica ciena po osobi 1 . for. Ovo mlado hercegovačko pjevačko družtvo, u nadi je da će se, ako ne svi, a to barem veći broj one gospode kojim je program poslat, odazvati, i tim njih osokoliti u svijem poduzeću. Mi smo stavni da jedino narodno pjevačko družtvo, koje ioli ima načelo naobrazivanja svoga naroda ono može mnogo više doprinieti koristi svojem narodu, negoli kakova druga družtva, koja se ustanovljivaju za jedino ono osoblje koje pripada tome družtvu."

162 "Zabava Narodnog pjevačkog društva", u: Glas Hercegovca, br. 46, Mostar, 5. 12. 1888.

163 Isto. "Izvođenju Graničara nazočan je Dragutin Freudenereich sin Josipa i veoma se pohvalno izrazio o izvedbi u Mostaru. Da u potpunosti ne može što ni najmanjeg zamjeriti, nit bi se to družtvo moglo zastiditi, da je ju prikazivalo i u 
sudionike priredbe: gospođice Pavković, Zelenika i Ančić kao i gospodu Šimuna Smoljana, Diku i Ančića. ${ }^{164}$ Kako društvo nije imalo svojih prostorija, zabava se održala u vojničko-činovničkom kažinu, a Odbor je Javnom zahvalom od 5. prosinca 1888. u Glasu Hercegovca br. 47, od 12. prosinca 1888. zahvalio na prostorijama i vojničkoj glazbi koja je besplatno ustupljena za tu prigodu. Javnu zahvalu potpisali su odbornici: Gj. Dika, I. Bašadur, N. Fišić, I. Smoljan, B. Zelenika i fra Augustin Zubac predsjednik Narodnog pjevačkog družtva u Mostaru.

Postoje oprječni podatci oko prvog javnog nastupa Narodnog pjevačkog družtva u Mostaru u Spomenici o 50-godišnjici Hrvatskog pjevačkog društva Hrvoje u Mostaru. Autor don Mate Nuić navodi da je prvi javni nastup 2. prosinca 1888. u Mostaru, pod vodstvom zborovođe fra Ambre Miletića, ${ }^{165}$ bio trijumf hrvatske narodne misli u gradu. Glas Hercegovca i u broju 47, od 12. prosinca 1888. u uvodniku $O$ četrdeset godišnjici donosi veliki prilog o samoj zabavi kao i programu koji su izveli članovi $\mathrm{Na}$ rodnog pjevačkog družtva prilikom svog prvog javnog nastupa. Program je sadržavao djela Ivana pl. Zajca $U$ boj u boj i S Velebita, zatim Pozdrav domovini kao i recitiranje Preradovićevih djela. Ovaj program, prožet hrvatskom idejom, naglasio je nacionalni preporod kod Hrvata. Uz građanstvo priredbi je nazočilo mnogo seljaka iz okolice Mostara. Mostarski su Hrvati mnogo pažnje posvećivali nacionalnom osvješćivanju sela i često su davali priredbe po obližnjim selima i organizirali izlete u okolicu. Ovaj datum nije točan i autor je predvidio da je prvi nastup bio 29. studenog 1888., ${ }^{166}$ a 2. prosinca 1888. je točno 40 godina od dolaska Franje Josipa I. na vlast i ta priredba je bila njemu u čast. Narodno pjevačko družtvo je organiziralo i jednu večeru, kojoj je nazočno preko 100 uglednih osoba,

kojem ovišem gradu, jer su lica tako vrlo dobro izveli svoju ulogu da bolje nije se moglo ni zahtjevati."

164 "Zabava Narodnog pjevačkog društva", u: Glas Hercegovca, br. 47, Mostar, 12. 12. 1888.

165 Spomenica o 50-godišnjici..., str. 14.

166 "Zabava Narodnog pjevačkog društva", u: Glas Hercegovca, br. 44, Mostar, 5. 12. 1888. Navodi se da je 29. studenog održana zabava povodom 40-godišnjice vladanja Nj. c. kr. Apostolskog Veličanstva Franje Josipa. Zabava je trajala od 7,30 do 2 sata nakon ponoći uz prisustvo 150 osoba. "Mi se radujemo ovom mladom Narodnom pjevačkom društvu na tom lijepom pokušanju, koji su znali tako krasno s prvim pokušanjem steći liepo ime kod svih slušatelja." U obje spomenice ovaj datum se ne spominje, nego samo 2. 12. 1888.; "40 godišnjica", u: Glas Hercegovca, br. 46, Mostar, 5. 12. 1888. Tri su svečanosti održane povodom toga: zabava 29. 11. 1888.; 2. 12. 1888. biskup Paškal Buconjić služio je svetu misu u znak zahvalnosti, a navečer je održana predstava u časničko-činovničkoj dvorani u korist siromašnih đaka. 
kod Ljoljina vira u Zahumu uz pratnju instrumentalne glazbe i pjevanjem zabavljalo goste. ${ }^{167}$ Društvo je odigralo veliku ulogu u razvitku glazbene kulture i stvorilo čitav niz glazbenika koji su svoja znanja prenosili na sljedeće naraštaje. Narodno pjevačko družtvo se proširuje 1889. godine kada je osnovana limena glazba, a 1891. godine ${ }^{168} \mathrm{i}$ ženski zbor, te se na taj način povećava broj članova i kvaliteta repertoara.

U Glasu Hercegovca najavljena je zabava koja će se održati 12. siječnja 1890. u prostorijama časničke i činovničke dvorane. U glazbenom dijelu programa sudjelovat će Vinko Šubir, Ančić, Smoljan i Ivan Dika, a u igrokazu Barun Franjo Trenk igrat će 21 osoba. ${ }^{169}$ Prilikom zabave Narodnog pjevačkog družtva, koja je održana 12. siječnja 1890. u prostorijama časničkog i činovničkog kasina u Mostaru, novi predsjednik društva fra Anđeo Nuić zahvalio je svima koji su pomogli rad društva. Pohvaljeni su izvođači pojedinih točaka, gospođice Dika, Bogošić, Ančić, A. Akšam, Halilović i Pavković, a od gospode braća Jure i Ivan Smoljan i Stanko Vladić. Financijska strana zabave bila je više nego uspješna jer je u društvenoj kasi ostalo 750 forinti. Nadaju se da će iduće godine društvo održavati zabave u vlastitoj zgradi. ${ }^{170}$ U Glasu Hercegovca br. 5, od 29. siječnja i br. 6, od 8. veljače 1890. pod naslovom "Milodari" doznajemo imena onih koji su na zabavi 12. siječnja dali svoj doprinos za boljitak Narodnog pjevačkog družtva te uočavamo da se javlja i ime pravoslavca Jove Šole iz Mostara, te stranci iz Monarhije koji su obavljali političke ili vojne dužnosti. Među katolicima, koji su dali milodare, imamo dosta trgovaca, posjednika, mlinara, svećenika, redovnika i učitelja. ${ }^{171}$ Tako se uska jezgra iz znanstvene

167 "Gostba pjevačkog družtva", u: Glas Hercegovca, br. 46, Mostar, 5. 12. 1888.

168 Spomenica o 50-godišnjici..., str. 15-16.

169 "Zabava", u: Glas Hercegovca, br. 2, Mostar, 8. 1. 1890.

170 "Narodno pjevačko družtvo", u: Glas Hercegovca, br. 3, Mostar, 15. 1. 1890. i "Zabava Narodnog pjevačkog družtva", u: Glas Hercegovca, br. 4, Mostar, 22. 1. 1890.

171 "Milodari", u: Glas Hercegovca, br. 5, Mostar, 29. 1. 1890. i br. 6, 8. 2. 1890. Uz one iz vlasti, crkve i vojske javljaju se i neka nova imena Risto Jelačić, Mate Zubac, Ante Sušac, Ivan Babić, Nikola Margeta, Stjepan Cvitanović, Ante Babić, Ante Malić, Pero Vasilj, Nikola Mandarić, Andrija Katušić, Petar Krešić, Marko Fontana, Mate Ljolje, Frano Ćorić, Jozo Mijić, Marko Šibić, Mate Tolić, Vein učitelj, Boško Galić, Jozo Markić, Grgo Ćuže, Luka Pišković, Ivan Gagro, Pero Komljen, Ilija Milićević, Ilija Stanić, Lovre Miloš, Stipo Tambić, Anto Kordić, Stjepan Zadro, Jure Zovko, učitelj Pero Bevanda, N. učitelj Nikola Ančić, Nikola Stojčić, Ante Botić, Jozo Kraljević, Ante Kovač, Ivan Landeka, Ivo Rudeš, Petar Vlaho, Ivan Šešelj, Ivan Šimunović, Stipe M. Tadić, Ljubica M. Tadić, don Lazar Lazarević, mlinar I. Zovko. Odbornici koji su dali milodar Ilija Katuradžija, fra Anđeo Nuić, Niko Friščić, Toma Kovač, Martin Čule, Ivan Smoljan i Ivan Dika. Broj 
propagande širi kako brojčano, tako i u strukturi građanstva. Narodno pjevačko družtvo je imalo zadatak da svojom pjesmom ne uspava narod, nego da ga probudi, osvijesti, bodri, prosvjećuje i kultivira. Na umjetničkom polju započeli su crkvenim pjesmama i rodoljubnim davorijama da bi nastavili, pod vodstvom F. Prohaske i Vinka Šubira, s izvođenjem složenijih djela kao što su opere i operete. Odlazeći na svečanosti izvan Mostara, u Sarajevo i Dubrovnik, Narodno pjevačko družtvo ubrzo postaje jedno od najcjenjenijih društava i bila je osobita čast kada je društvo nastupalo. Povodom imendana biskupa fra Paškala Buconjića 17. svibnja 1890. Narodno pjevačko družtvo je prvi put otpjevalo serenadu njemu u čast. Tom prilikom, ovo jedino narodno glazbeno društvo u Bosni i Hercegovini, otpjevalo je Liepa naša domovino, Carevku, Prosto zrakom i Banovci. Bilo je jedino društvo u Bosni i Hercegovini koje je imalo glazbu, a dolaskom novog zborovođe Vinka Šubira ${ }^{172}$ znatno je podignuta kvaliteta glazbenoga izvođenja. U ime Narodnog pjevačkog družtva biskupu je imendan čestitao predsjednik fra Anđeo Nuić i naglasio da mu želi puno sreće i uspjeha u radu. Pohvaljuje se rad zborovođe Vinka Šubira, koji je za nekoliko mjeseci na prvom javnom pokusu pokazao da je na dobrom putu. U svome komentaru o prvom nastupu "narodne pjevačke glazbe, mi se radujemo i čestitamo cielom družtvu na njegovu poduzeću, kao što i gospodinu zborovođi Vinku Šubiru, koji je kroz ovo malo mjeseci tako liepo znao svoju uputu predstaviti publici na diku cielog družtva". ${ }^{173}$

Društvo je nazočno i na sahranama istaknutih Hrvata u Mostaru. Povodom smrti Joze Zovke, oca dičnog učitelja Narodne osnovne škole, koji je bio jedan od prvih trgovaca, društvo aktivno uzima učešće u sahrani. Obitelj pokojnika javno se zahvalila u Glasu Hercegovca: "A osobita hvala i blagodarnost neka bude ovdašnjem narodnom pjevačkom društvu, kojem će mo vječno biti zahvalni, što je svojim posvetom i pjesmom žalobnicom sprovod našeg milog i nikada nezaboravnog pokojnika ukrasilo i počastilo."174

Društvo se širi i poduzimaju se aktivnosti kako bi nabavili glazbene instrumente za svoje potrebe i tada se javljaju pojedinci s dobrovoljnim pri-

onih koji pomažu je povećan kao i njihova socijalna struktura što govori o širenju prvotne uske jezgre u šire društvene slojeve. Uz katolike među onima koji daju svoj doprinos uočavamo pravoslavne, muslimane i doseljenike iz Monarhije.

172 Ivica Golec, Hrvatsko pjevačko društvo Slavulj Petrinja 1864.-2004., Petrinja, 2010., str. 114-123. Radio u Radničkom pjevačkom društvu Slobodi u Zagrebu nakon Petrinje. U Mostar dolazi 30. listopada 1889. na poziv fra Augustina Zubca prvog predsjednika Narodnog pjevačkog društva u Mostaru.

"Javna zahvala", u: Glas Hercegovca, br. 21, Mostar, 28. 5. 1890. 
lozima za tu svrhu. ${ }^{175}$ Kada pogledamo strukturu onih koji daju milodare, možemo izdvojiti svećenike, službenike, liječnike, posjednike, trgovce, obrtnike, učitelje i vojna lica. Posebno je uočljivo da su trgovci i posjednici, Hrvati iz Mostara, koji prednjače sa svojim prilozima. Priloge daju i pojedinci iz Brotnja, Ljubuškog, Stoca, Metkovića, Konjica, Cima, Nevesinja, Gabele, Bune, Crnča, Dubrava, Županjca, Mamića, Kreševa, Brača, Širokog Brijega, Glavatičeva, Broda, Mokroga, Goranaca, Rasna i Drežnice. ${ }^{176}$

Vinko Šubir djeluje kao zborovođa Narodnog pjevačkog družtva u Mostaru i podučava pjevanje i sviranje glasovira kao učitelj te na taj način pridonosi širenju glazbene kulture u Mostaru. ${ }^{177}$

Nakon održane zabave, Glas Hercegovca br. 3, od 15. siječnja 1890. pod naslovom Narodno pjevačko družtvo, donosi utiske sa zabave. Naglašava ulogu zborovođe Vinka Šubira u uspjelom izvođenju programa na kojem je bila mostarska inteligencija, časnici, biskup, svećenici i činovnici. Zabavi je prisutno dosta građana svih vjeroispovijesti, kao i posjetilaca iz okolice.

Na ovaj su način žene uključene u rad društva kroza zbor, dramsku i recitatorsku sekciju. Narodno pjevačko društvo je i na ovom polju odigralo pionirsku ulogu i omogućilo ženama da pokažu svoj umjetnički dar. Veliki

175 "Dobrovoljni prinosi", u: Glas Hercegovca, br. 1, Mostar, 2. 1. 1889. "...uz pomoć gospodina Nike Fišića darovaše: Velem. G. okr. Upravitelj i vladin savjetnik Muller f. 50.- P. i P. biskup gosp. Buconjić, 50.- bisk. tajnik O. Augustin Zubac 40.- župnik Kočerina Fra Ilija Lekić 5.- župnik Fra Ilija Zelenika 5.- provincijal O. Lujo Radoš 5.-Doktor Petar Rizzo 50.- N.N. 1.- Andro Stamburk, Gambetta 15.- trgovac Niko Fišić 100.- trgovac Ivan Bašadur 50.- posjednik Mato Šahin 20.- podnačelnik Blaško Zelenika 15.- Bajo Božić pol. Adjunkt 5.- Toma Kovač 10.- posjenik Marko Šešelj 10.- posjednik Ivan Smoljan 10.- posjednik Ilija Ćuk 10.- posjednik Pero Kurtaga 10.- Šimun Miličević posjednik 10.- trgovac Ivan Dikka 20,80.- posjednik Mijat Merdžo 10.- župnik Gorice O. Jerko Ljubić 10.obć. mjernik Marko Fontana 5.- Andro Erceg 5.- posjednik Pero Bogut 5.- Marko Ančić 1.- posjednik Jakov Lovrić 1.- Ivan Zovko 2.- vojn. kapelan Mat. Kabelka 2.- Petar Markić 1.- Pero Komljan 5.- Braća Vranjković 10.- Mato Marinović 3.Ivan Ivanković 10.- Lujka Galjanović 10.- posjednici Mato Pero Stjepan Smoljan 15.- posjednik Jure Smoljan 10.- Mato Krezić 10.- Ante Butigan 10.- majstor Ivan Zovko 1.- Jure Kovač 2.- Pavo Šarić 1.- Miško Kovač 1.- Ivan Banoža 2.- Nikola Banoža 1.- Anto Ćuže 1.- Grgo Ćuže 5.- Marija Zlomislić 2.- Mato Soldo 2.- Ivan Šoić 5,70.- Mato Tolić 1.- Ukupno f. 641 nč. 50. Dodavši prihod milodara označeni u br. 49. f. 1815. nč. 84. ukupno iznosi f. 2457 nč. 39." Prilozi su sakupljani i u 1888. godini o čemu nalazimo podatke u broju 47, od 12. 12. 1888. i br. 48, od 19. 12. 1888. ukupno f. 1187,84 i br. 49 , f. 628 što je zbrojeno ukupno f. 1815,84.

176 "Dobrotvorni milodari", u: Glas Hercegovca, br. 48, Mostar, 19. 12. 1888.

177 "Vinko Šubir", u: Glas Hercegovca, br. 48, Mostar, 19. 12. 1889. 
broj Hrvatica iz Mostara nastupit će na predstavama, zabavama i sijelima koje organizira društvo, a neke od njih nastupat će kao gošće prilikom dolaska u Mostar drugih dramskih grupa. Istaknutije članice odlaze u druge sredine nastupati u njihovim predstavama. ${ }^{178}$

Prilikom svečanoga polaganja temeljnog kamena za Franjevački samostan u Mostaru 14. ožujka 1890. provincijal Nikola Šimović nazdravio je fra Anđelu Nuiću i učitelju Vinku Šubiru: "pod kojim skrbi ovo narodno pjevačko družtvo stoji, da ih Bog požive, da njima povjerena mladež, bude na diku svoga naroda i u sretnom napredku njihovog poduzeća". ${ }^{179} \mathrm{U}$ svojoj zahvali fra Anđeo Nuić je među ostalima zahvalio zborovođi Vinku Šubiru: "...i izjavio mu da je sa svim zadovoljan sa pjevanjem pjevačkog društva, tako da ga je iznenadilo kroz tako kratko vrijeme, da je mogla mladež i bez orgulja tako milozvučno Misu odpjevati, čemu su se sva gospoda divila." 180 Jedna od većih donacija za izgradnju Franjevačkog samostana u Mostaru bila je ona zagrebačkoga nadbiskupa Josipa Mihalovića u iznosu od 1000 forinti. ${ }^{181}$

Prilikom rođendana Franje Josipa I., 17. kolovoza 1890., Narodno pjevačko družtvo priređuje koncert u bašči uza sudjelovanje glazbe društva. Naglašavajući značaj društva i glazbe koji imaju "...zadatak gojiti glasbu u svakoj grani a time buditi svest narodnu: što pjesmom što glasbom, što predstavom; tako, da naša mladež promatrati može podpuno svoj uzvišeni cilj, svoj zadatak, podnipošto pako, ko što njekoji misle otvoriti iz društva muzikante koji od gostione do mehane muziciraju za njekoliko groši, a time da se nauče smo piti i noći zaostajati, kako to u više mjestih se dogadja. Naše narodno pjevačko družtvo ustanovljeno je da bude u glavnom gradu mile nam domovine ogledalom ostalih gradova, da goji glasbu na čast i diku svome narodu, a time da postigne onaj cilj za kojim svaki naobraženi narod teži. Pjesmom za dom neka bude geslom vriednog nam pjevačkog društva."182

Društvo je stalno mijenjalo lokacije svojih zabava, a kada je dobilo dopuštenje da može organizirati zabavu u prostorijama novog hotela Narenta u Mostaru, bio je to veliki iskorak u radu društva. Ovom događaju, 7. i 8.

178 Hrvatsko glazbeno-pjevačko društvo Hrvoje Mostar 120. obljetnica, Mostar, 2008., str. 19; kao glumice ističu se: Jelka Soldo, Ruža Hristić, Stanka Hristić i Ana Halilović.

179 "Samostan Franjevački u Mostaru", u: Glas Hercegovca, br. 13, Mostar, 26. 3. 1890.

180 Isto.

181 "Velikodušni dar", u: Glas Hercegovca, br. 30, Mostar, 30. 7. 1890.

182 "Dopisi", u: Glas Hercegovca, br. 31, Mostar, 2. 8. 1890. 
prosinca 1890., bilo je nazočno oko 850 posjetitelja. Program je bio glazbeni, recitatorski i izvedena je predstava Zvonimir kralj Hrvatski. ${ }^{183}$

Sudionici na zabavi su: Jure Smoljan, koji je recitirao San i javu od K. Kutana, mješoviti zbor koji se sastojao od šest gospođica i pet dječaka, ${ }^{184}$ a devet članova društva otpjevalo je Domovini i Šumski čar od I. pl. Zajca. Vinko Šubir ${ }^{185}$ nastupio je sa svojim programom, a na kraju su svi zapjevali "...hrvatsku marselesu Živila Hrvatska, da se morala ova točka opetovati to se samo po sebi razumjeva i da je bio skladatelj izazvan".186 $\mathrm{U}$ programu su nastupile gospođice Bokšić, Ančić, Akšam i Jelka Smoljan, zatim gospoda Šimun Smoljan, Vladić, Ljolje, Ančić, Soldo i I. Smoljan. Pohvala je izrečena i Odboru društva na čelu s predsjednikom fra Jerkom Ljubićem, odbornicima Fišićem, Dikom i Šajinom. Na obje večeri bilo je šezdeset muslimanskih odličnika koje posebno u tekstu Sirom domovine Glas Hercegovca pozdravlja i naglašava da su javno pokazali pred svijetom što su i tko su. ${ }^{187}$ Ove zabave su pokazale da se u jednom kratkom razdoblju društvo proširilo, podiglo kvalitetu svojih amaterskih nastupa i da je imalo veliku publiku koja je u zavidnom broju dolazila na njihove priredbe. Ostao je problem nedostatka prostorija koji je trebalo riješiti kako bi se stekli bolji uvjeti za probe i mjesto gdje će organizirati svoje nastupe. Uključivanjem građanstva $u$ rad društva i širenjem strukture posjetitelja označilo je širenje procesa nacionalne agitacije na građansku klasu u Mostaru. Svojim dolaskom na priredbe, seljaci iz okolice grada uključuju se $\mathrm{u}$ integracijske procese $\mathrm{i}$ tako se ta ideja širi i na najbrojniji sloj hrvatskog pučanstva. ${ }^{188}$ Osim rada na polju, pjevanja, glazbe i glume pažnja je poklanjana prosvjetnom napretku članova kao i posjetitelja zabava. Organiziraju se popularna predavanja jednom tjedno iz različitih područja. Teme su bile iz povijesti i kulture hrvatskoga naroda, ali i drugih naroda. Pokušaj osnivanja knjižnice išao je teško jer je vlast radila preveliku kon-

183 "Večernja zabava", u: Glas Hercegovca, br. 63, Mostar, 15. 12. 1890.

184 "Večernje zabave", u: Glas Hercegovca, br. 10, Mostar, 14. 2. 1891. U osvrtu na zabavu od prije dva mjeseca navodi da su nastupila 4 dječaka.

185 "Zahvala", u: Glas Hercegovca, br. 66, Mostar, 24. 12. 1890. "Štovani gospodine uredniče! Molim, da uvrstiti izvolite u Vaš cienjeni list sljedeću zahvalu. Prigodom zabave Narodnog pjevačkog družtva počasti me je slavni odbor obiljnijom nagradom, za koju se istom javno najsrdačnije zahvaljujem. Platio Vam Bog ! Mostar, 22. prosinca 1890. godine. Sa poštovanjem Vinko Šubir sborovođa." Ova vijest govori da su članovi društva bili zadovoljni s radom zborovođe i da su znali cijeniti njegov trud i umijeće.

186 "Večernja zabava", u: Glas Hercegovca, br. 63, Mostar, 15. 12. 1890.

187 "Širom domovine", u: Glas Hercegovca, br. 64, Mostar, 17. 12. 1890.

188 "Milodari", u: Glas Hercegovca, br. 2, Mostar, 10. 1. 1891. i br. 3, 14. 1. 1891. 
trolu naslova, a svi oni naslovi koji nisu odgovarali, završili bi na lomači Nakon toga mogla je započeti knjižnica s radom. Samo su se odobreni listovi mogli nalaziti u čitaonici: Narodni list, Obzor, Katolička Dalmacija, Crvena Hrvatska, Naša sloga, Srpski list, Bošnjak, Sarajevski list, Dom i svijet, Istra, Zvekan i Glas Hercegovca. ${ }^{189}$

Zabavama društva prisustvuju muslimani i pravoslavni iz Mostara, a Osman beg Štafić je za Narodno pjevačko družtvo u Mostaru spjevao dvije pjesme koje su preslikane iz Glasa Hercegovca i prodaju se za 4 novčanice s poštarinom ili u uredništvu Glasa Hercegovca. ${ }^{190}$

Narodno pjevačko družtvo održalo je veliku zabavu 8. prosinca $1891 .{ }^{191} \mathrm{uz}$ nazočnost oko 300 posjetitelja, od toga je bilo 30 do 40 muhamedanaca, a Srbi su pokušali remetiti mir pa su na vrijeme izbačeni. Program predstave bio je uobičajen i sastavljen od pjesama, recitacija i drame, a sve se završilo plesom do kasno u noć. Predstavi su bili nazočni i gosti iz susjednih kotara, a posebno iz Metkovića, na čelu s predsjednikom čitaonice u Metkoviću gosp. Tadićem. ${ }^{192}$ Brojni brzojavi iz Zagreba, Karlovca, Siska, Graca u Štajerskoj, Trsta, Praga, Križevaca, Beča i Kiseljaka upućeni su Narodnom pjevačkom družtvu u Mostaru. Brzojavi su prožeti nacionalnim zanosom i pozdravljaju Hrvate u Hercegovini, a brzojav iz Siska glasi: "U velikom broju skoro cielo gradjanstvo sisačko sakupljeno na izbornom sastanku pozdravljaju junačke Hercegovce pozdravljaju dične Hrvatice i Hrvate Mostarske, orio se glas Hercegovaca širom svih Hrvatskih zemalja Mi tražimo što je naše. Živila Hrvatska!"193 Glas Hercegovca pred Božić 1891. godine donosi veliki članak "Božićne misli" u kome se osvrće na

189 Hrvatsko glazbeno-pjevačko društvo Hrvoje Mostar 120..., str. 101-106.

190 "Dvije pjesme", u: Glas Hercegovca, br. 80, Mostar, 21. 11. 1891.

"...Da brat brata rasposnat nemože;

Tad nas bjesom razdora rascjepa,

Pak nas mržnje sljepilom opojeni:

Jedan drugog klasmo ko maneni

Htjede ljuta da nas izkorjeni.

Zrinjski bane, Sokolović paša!

Oba rana, oba dika naša!

Da ste znali, što ste oba dužni

Naspram slavnoj majci vam Hrvatskoj,

Ne bi bili tuđe tudje volje sužnji."

191 "Zabava", u: Glas Hercegovca, br. 84, Mostar, 12. 12. 1891.

192 Isto.

193 Isto. 
sjajnu zabavu od 8. prosinca kao i zagrebačku izložbu gdje: "...je bosanski, hercegovački Hrvat s bratom se ogrlio, na junačke grudi privio, gdje su se opeta sakupili na junačkom sboru. Tu je Hrvat Hrvatu iz rastrganih djelova jedne majke pokazao što umije, što znade! Dičimo se uspjehom izložbe jer je ona bila i naš trud i naša slava!... Svi za jednoga, jedan za sve! Veselimo se spomeni onoj, koja nam šapće o produbljenoj hrvatskoj sviesti! Veselimo se jer nam je ova godina u stotine i stotine prigoda pokazala da nas Velebit, more jadransko, od braće nedieli; da je Sava preuska i preplitka a da ju neprigazimo i ne pružimo bratske ruke! Kao melem kaplja godila nam divna i sjajna zabava narodnog pjevačkog družtva u Mostaru. Slava vam svjestni otačbenici, slava vam trista puta na vašem otačbeništvu, na vašem neumornom nastojanju. Hvala vam trista puta za one neopisive sladke čase čisto hrvatske zabave."194

Na Božić je misu slavio biskup fra Paškal Buconjić, a Narodno pjevačko družtvo sviralo je i pjevalo te na taj način uzveličalo ovaj veliki katolički blagdan. ${ }^{195}$

Milodari, koji su darovani društvenoj zakladi, dolaze od pojedinaca iz: Mostara, Metkovića, Klobuka, Ljubuškog, Blizanaca, Međugorja, Cima, Čapljine, Sarajeva, Donje Tuzle, Zagreba, Krakova, Bosanskog Novog, Rodoča, Šurmanaca, Makarske, Šrokog Brijega, Travnika, Siska, Pologa, Opuzena, Konjica, Bjelovara, Dubrovnika, Karlovca, Čerina, Bune, Crnča, Stoca, Nevesinja, M. Bistrice, Splita, Livna, Hrvatske Dubice, Tugara, Imotskog, Jelse, Otočca i Kreševa. ${ }^{196} \mathrm{Uz}$ pojedince javljaju se i udruženja: Hrvatska čitaonica Metković, Družtvo obrtničkih radnika Sisak, Družtvo Protujelen Zagreb, Veselo družtvo u Gospiću, Hrvatska čitaonica na Trsatu. ${ }^{197}$ Iznos koji je sakupljen ovim milodarima iznosio je 741 for. i 12 novč. Milodari koji su upućeni za napredak Narodnog pjevačkog družtva dokaz su njegova uspješnog djelovanja i uloge koja je prešla granice grada Mostara i Hercegovine.

Koliko su zabave bile značajne za hrvatski narod, svjedoče i brojni brzojavi potpore. Oni su ujedno i putokaz da je Narodno pjevačko družtvo u Mostaru na pravom putu i da okuplja oko sebe sve što je vrijedno i nacionalno svjesno. Ono je postalo jezgra koja okuplja Hrvate u Mostaru i Hercegovini oko narodne ideje. Suradnja s drugim hrvatskim krajevima pokazuje da je Narodno pjevačko družtvo proširilo svoje vidike i postalo prepoznatliivo po svome radu.

194 "Božićne misli", u: Glas Hercegovca, br. 86, Mostar, 23. 12. 1891.

195 "Na božić", u: Glas Hercegovca, br. 88, Mostar, 30. 12. 1891.

196 "Milodari", u: Glas Hercegovca, br. 88, Mostar, 30. 12. 1891.; br. 1, 6. 1. 1892.

197 Isto. 
Obilježavajući poklade, organizirana je u prostorijama Grand Hotela Orijent u Mostaru pokladna zabava uza zbor, tamburaše i glumačku družinu. ${ }^{198}$ Oko zabave je izbio sukob s vlasnicima hotela koji su podigli cijenu najma prostorije gdje se održavala zabava. Vlasnici hotela su Żidovi pa je izašao članak u Glasu Hercegovca "Židovski pojavi" u kome osuđuju ponašanje Židova u Mostaru, a daju primjer kako se ponašaju Židovi u Zagrebu. ${ }^{199}$

Aktivnosti oko gradnje doma Narodnog pjevačkog družtva u Mostaru potenciraju se u svakoj prigodi. Imena dobročinitelja Glas Hercegovca objavljuje iskazujući im na taj način zahvalu. ${ }^{200}$ Zabavu društvo organizira 16. kolovoza 1894. u društvenim prostorijama s pjevačko-glazbenim i dramskim programom, te tombolom. ${ }^{201}$ Koliko je pažnje posvećeno djelovanju Društva u Mostaru svjedoči nam i članak "Naše nar. glas.-pjev. družtvo"202 u Glasu Hercegovca u kojem se daje osvrt na djelovanje društva i njegove potrebe u budućnosti. Pozivaju se rodoljubi da pomognu ovu akciju oko izgradnje doma za društvo. ${ }^{203}$ Koliko je Narodno glasbeno-pjevačko družtvo u Mostaru bilo već poznato i izvan Hercegovine govore nam milodari koje su dobili za gradnju doma od arhiđakona Milka Cepelića iz Đakova 10 for., okružnog predstojnika u D. Tuzli Miroslava Foglara 5 for., trgovaca Ivana Jerkovića 5 for. i Antuna Pachera 2 forinte. ${ }^{204}$ Nedostatak prostora i rad društva u tuđim prostorijama bratovštine, s kojom dolazi do nesporazuma oko plaćanja najamnine, natjerali su članove da razmišljaju o gradnji svoga doma u Mostaru. Ovu akciju prihvatili su, ne samo članovi iz Mostara, nego i brojni Hrvati iz: Metkovića, Vrgorca, Stona, Grabovice i Livna. Iz ovakvih vijesti uočavamo povezanost s Dalmacijom kao i da su u proces integracije uključeni trgovci, posjednici, činovnici, učitelji i obrtnici iz Hercegovine kod kojih se razvija narodna svijest.

198 "Pokladne zabave", u: Glas Hercegovca, br, 15, Mostar, 24. 2. 1892.

199 "Židovski pojavi", u: Glas Hercegovca, br. 24, Mostar, 30. 3. 1892.

200 "Milodari za gradnju doma Narodnog pjevačkog družtva u Mostaru", u: Glas Hercegovca, br. 3, Mostar, 17. 1. 1894. Nalazimo pojedince iz Livna, Stona, Vrgorca, Metkovića, Grabovice i Mostara.

201 "Zabava", u: Glas Hercegovca, br. 39, Mostar, 15. 8. 1894.

202 "Naše nar. glas.- pjev. družtvo", u: Glas Hercegovca, br. 60, Mostar, 18. 8. 1894.

203 Isto. "Mi našu iskrenu rieč iztaknusmo, stavljamo na razmišljanje ljubiteljima naše hrvatske prosvjete. A u isto doba molimo svu braću hrvatsku, da razmišlivši što bolje o tom, te da rodoljubivim darovim priteku u pomoć ovom našem 'Narodnom glas.-pjev. družtvu' - u Mostaru, da zasnovano djelo dokrajči. Pa Bog i Hrvati!"

204 "Milodari", u: Glas Hercegovca, br, 71, Mostar, 3. 10. 1894. 
Prilikom organiziranja zabava nastojala se dati nacionalna obojenost pa je: "...od I. Bosiljevca izvedena pjesma Živila Hrvatska koju je otpjevao mješoviti zbor društva". ${ }^{205}$ Kolika je važnost pjevačkog društava u Mostaru i razvoj društava u drugim sredinama, naglašava Glas Hercegovca u svom uvodniku br. 60, od 18. kolovoza 1894. s naslovom "Naše nar. glas.-pjev. družtvo" te zaključuje da je društvo napredovalo u kratkom razdoblju nakon osnivanja. Naglašava se potreba gradnje društvenih prostorija jer u gradu nema prostorije gdje bi moglo prikladno nastupiti. Organiziraju nastupe gdje sav prihod ide za gradnju društvenoga doma. Pozivaju se svjesni Hrvati da svatko prema svojim mogućnostima podrži ovu akciju.

Glas Hercegovca pod naslovom "Pjevački savez" donosi ideju da se osnuje savez pjevačkih društava Herceg-Bosne radi daljnjeg napretka društava. ${ }^{206}$ Ovako bi se društva mogla bolje potpomagati i osnivati nova pjevačka društva po Hercegovini i Bosni. Društvo je 2. listopada 1894. izgubilo jednog vrijednog člana, Niku Fišića, koji je preminuo u 54. godini, a članstvo je nazočilo ukopu. ${ }^{207}$

Nakon što je održana Glavna skupština u novi Odbor su izabrani: predsjednik Martin Čule, blagajnik Ilija Ivanković, tajnik Petar Ančić, arhivar Petar Soldo, odbornici: don Frano Milićević, Ivan Smoljan, Marko Šiljeg, Petar Kurtaga, Ivan Ivanošević, Blaž Merdjo, Stipan Smoljan, Vjeko Stambuk i Jozo Škrobić. ${ }^{208}$ Krajem studenoga 1894. Narodno glasb. pjev. družtvo organiziralo je zabavu uz potporu vojničke glazbe. Velik broj posjetitelja bio je u neuvijetnim prostorijama. Mnogi nisu mogli prisustvovati pa je zatraženo da se zabava još jednom ponovi. ${ }^{209}$ Narodno glasbeno-pjevačko družtvo je 2. prosinca 1894. priredilo glavnu zabavu u prostorijama $\mathrm{Ho}$ tel Kroprinza, a milodare je primao predsjednik Martin Čule. ${ }^{210}$ Obilježavajući vjerske blagdane, pjevači Narodnog pjevačkog družtva sudjeluju u obredima za Božić, Uskrs, Brašančevo i Veliku Gospu, uveličavajući te događaje. ${ }^{211}$

205 "Zabava", u: Glas Hercegovca, br. 59, Mostar, 15. 8. 1894.

206 "Pjevački savez", u: Osvit, br. 61, Mostar, 25. 8. 1894.

207 "Javna zahvala", u: Glas Hercegovca, br. 70, Mostar, 29. 9. 1894. Pokojni je bio odbornik i potpisnik prvih Pravila koja su odobrena 10. 11. 1888.

208 "Domaće viesti", u: Glas Hercegovca, br. 79, Mostar, 31. 10. 1894.

209 "Zabava", u: Glas Hercegovca, br. 88, Mostar, 1. 12. 1894.

210 "Domaće viesti. Godišnja zabava", u: Glas Hercegovca, br. 88, Mostar, 29. 11. 1894.

211 "Brašančevo", u: Glas Hercegovca, br. 40, Mostar, 19. 6. 1895. 
Tijekom 1895. godine Narodno glasbeno pjevačko družtvo Hrvoje nastavlja sa svojim aktivnostima i najavljuje zabavu 29. lipnja 1895., ${ }^{212}$ a ona je održana tek 14. srpnja 1895. Zabava je imala dosta kvalitetan glazbeni i dramski program pod ravnanjem Vinka Šubira. Pozivnica je poslana i Glazbenom pjevačkom društvu Slavulj u Trebinju. Društvo sudjeluje u svečanosti polaganja temeljnog kamena za crkvu u Konjicu 20. srpnja 1895. i na zabavi koja je večer prije organizirana. ${ }^{213}$

Društvo je nakon dolaska novoga okružnog predstojnika J. Vojvodića i povjerenika grada O. Kinburga uputilo svoje izaslanstvo da im izjave lojalnost Hrvata u Mostaru. ${ }^{214}$ Tijekom 1896. godine obilježavaju se važni događaji i za katoličke svetkovine priređuje zabave. Povodom pedesetogodišnjice dolaska franjevaca u Hercegovinu održalo je svečani koncert u Mostaru i veliku zabavu na Širokom Brijegu. Kako se društvo proširilo sa svojim sekcijama i brojčano, javila se potreba prikladnog smještaja. Akcija oko izgradnje Hrvojevog doma nije ni 1896. godine odobrena od vlasti. Našlo se rezervno rješenje i uz pomoć Bratovštine sv. Ante prišlo se dogradnji već postojećeg objekta. Uz novac dobiven od dobročinitelja ${ }^{215}$ podignut je hipotekarni kredit, a nacrt dogradnje izradio je ing. Miloš Komadina.

Narodno glasbeno pjevačko društvo Hrvoje priredilo je svoju glavnu godišnju zabavu u Domu Bratovštine 2. veljače 1897. kada su svečano otvorene nove prostorije. Program zabave je pomno odabran: muški zbor pjeva Liepa naša domovino, gđica Jelka Soldo krasnoslovi Naše ime, mješoviti zbor pjeva Himna Slavensko-Hrvatske omladine, gosp. G. Kvesić krasnoslovi Otačbini, muški zbor pjeva Hrabren Hercegovac, mješoviti zbor pjeva Jorgovan i slavulj. Za glumački dio zabave odabrana je Crna kraljica koju su igrali gđice: S. Hrstić, J. Budimir i R. Hrstić, gosp. A. Kvesić, B. Soldo, M. Mihić, T. Sučić, J. Pavlović, A. Pavković, A.

212 "Domaće viesti", u: Glas Hercegovca, br. 41. Mostar, 22. 6. 1895. ispravak u br. 43, 3. 7. 1895.; ispravak održavanja zabave zbog nepredviđenih okolnosti i novi datum održavanja 7. 7. 1895., a zabava je prolongirana za 14. srpnja zbog vremenskih neprilika.

213 "Iz naših pokrajina", u: Glas Hercegovca, br. 47, Mostar, 17. 7. 1895.

214 "Iz društva", u: Glas Hercegovca, br. 83, Mostar, 11. 12. 1895.

215 "Domaće viesti", u: Glas Hercegovca, br. 3, Mostar, 17. 1. 1894. "Milodari za gradnju doma Narodnog pjevačkog družtva u Mostaru. N.S. J. Kojić trgovac Livno for.5.- Mate Ćubela Grabovića for. 1.- Eduard Milović veleposjednik, Ston 50. for.- Jerko Jerkić trgovac Metković for. 5.-Dr. Bibica liječnik Vrgorac for. 5.- Mate Kovačević trgovac Vrgorac for. 5.- Pavo Smoljan Mostar 68 nč.- Ivan Curić Mostar 68 nč.- Jure Smoljan trgovac Mostar 50 nč. Ukupno 78. f., 86. nč." 
Šiponi, A. Miljan i P. Kalanović. ${ }^{216}$ Ovo je bio važan datum u povijesti jer su stvoreni uvjeti za novi iskorak u radu društva. Brojne čestitke primio je GPD Hrvoje iz Dalmacije i drugih krajeva gdje žive Hrvati. Zagrebačke gospođe darovale su zastor za veliku salu. ${ }^{217}$

Narodno glazbeno pjevačko društvo u Mostaru organizira 7. lipnja 1897. zabavu u Domu Bratovštine s glazbenim i glumačkim programom, a ovaj put izabrana je tragedija Mirka Bogovića Matija Gubec kralj seljački. ${ }^{218} \mathrm{Na}-$ redna zabava održana je 17. listopada 1897., a ovaj put izvedena je šaljiva igra u pet činova. ${ }^{219}$ Još je organizirana zabava 8. prosinca 1897. u domu Bratovštine, a uz glazbeni program izvedena je tragedija Stjepan Tvrtko prvi kralj bosanski. ${ }^{220}$

Jedna od uspjelih zabava u kazališnoj dvorani doma Bratovštine koju je priredio Hrvoje održana je 4. rujna 1898. Posjećenost je bila veoma dobra pa je zadovoljan bio i Jure I. Smoljan, blagajnik Hrvoja, na prodanim ulaznicama, a priličan broj muslimana nazočio je zabavi. ${ }^{221}$ Glavna Skupština Narodno-glasbenog-pjevačkog družtva Hrvoje održana je 9. listopada 1898. Fra Radoslav Glavaš, u ime odsutnog predsjednika Martina Čule, otvorio je Skupštinu. Tajnik Milićević je izvijestio o radu u protekloj godini u kojoj je održano šest zabava, dva sijela i četiri puhačka glazbena koncerta. U posjetu je bio Ivan vitez Trnski sa svojom kćeri koja je poklonila zastor za kazalište u ime zagrebačkih Hrvatica. Jure I. Smoljan izvijestio je o stanju blagajne, a prijedlog Petra Solde, da se promijeni naziv društva umjesto Narodno glasbeno pjevačko družtvo Hrvoje u Narodno hrvatsko glasbeno pjevačko družtvo Hrvoje, s oduševljenjem je prihvaćen. Dogovoreno je da s ostalim hrvatskim društvima stupi u Savez hrvatskih pjevačkih družtava u Herceg-Bosni. ${ }^{222}$ Dosadašnji predsjednik Martin Čule, koji je tu čast obavljao punih deset godina od osnutka, imenuje se počasnim članom. Novi predsjednik je Ivan A. Milićević, tajnik Stjepan Radulović, blagajnik

216 ABiH Sarajevo, Napretkova kulturno-historijska zbirka 1140/IV, Program zabave 2. 2. 1897.

217 Hrvatsko glazbeno-pjevačko društvo Hrvoje Mostar 120. obljetnica, Mostar, 2008., str. 23-24.

218 ABiH Sarajevo, Napretkova kulturno-historijska zbirka 1141/IV, Program zabave 17. 6. 1897.

219 ABiH Sarajevo, Napretkova kulturno-historijska zbirka, 1156/IV, Program zabave 17. 10. 1897.

220 ABiH Sarajevo, Napretkova kulturno-historijska zbirka 1122/IV, Zabava 8. 12. 1897.

221 "Hrvojeva zabava", u: Osvit, br. 13, Mostar, 7. 9. 1898.

222 "Glavna godišnja skupština Hrvoje", u: Osvit, br. 23, Mostar, 12. 10. 1898. 
Pero Smoljan, knjižničar Ivan Akšam, arhivar B. Soldo, odbornici: Toma Kovač, David Nevistić, Tomo Ljolje i Ivan Smoljan. ${ }^{223}$ Jedna od odluka je uvođenje sijela svaki tjedan, ali samo za članove Hrvoje. Ovo je završetak amaterskog pristupa i HGPD Hrvoje bolje priprema i izvodi komade te u narednoj 1899. godini prikazuje 13 predstava, od toga 8 premijera.

Već početkom godine Hrvoje organizira svoju zabavu s plesom, ${ }^{224}$ ali je posjećenost mogla biti bolja. Pjevačkim zborom ravnao je J. Beraković, a amateri su izveli Pradjedovu sliku Janka Jurkovića, koja nije polučila očekivanu razinu na koju su bili naviknuti gledatelji. ${ }^{225}$ Sličnu zabavu organizira i za poklade. Ovo je bila prva zabava kada Hrvatsko glasbeno-pjevačko družtvo Hrvoje izlazi pred građanstvo s hrvatskim imenom, a kako je u svom nadahnutom obraćanju naglasio predsjednik Ivan A. Milićević, to je stečevina za čitav hrvatski narod u Bosni i Hercegovini. ${ }^{226}$ Ovo je dalo novi poticaj članovima Hrvatskog glasbeno-pjevačkog družtva Hrvoje za daljnji rad u hrvatskom duhu i to je putokaz za budućnost. Vrijeme korizme su iskoristili za pripremu kako bi za Uskrs mogli prirediti velebnu zabavu. ${ }^{227}$ Prilikom otvaranja Hrvatske dioničke tiskare u Mostaru, ${ }^{228}$ koja je 6. ožujka 1899. potvrđena od vlasti, HGPD Hrvoje priredio je zabavu povodom tog važnog događaja za Hrvate u Hercegovini. ${ }^{229}$ Osvit je u uvodniku, koji je uokviren hrvatskom trobojnicom, pod naslovom "Za hrvatsku stvar" naglasio: "Slavimo riedku slavu: otvorenje prosvjetnog zavoda, koji je namijenjen hrvatskoj stvari, narodnoj prosvjeti, zavoda, što ga je narod sam podigao svojim žuljevima u osvjedočenju, da stvara nešto, što će trajno služiti njemu i njegovim svrhama. Ovo je jedan od poznatijih čina, što ih je hrvatski narod u Bosni i Hercegovini u novije doba izveo, i ova bi slava morala odjeknuti po čitavom hrvatskom narodu, imala bi biti obća

223 Isto.

224 ABiH Sarajevo, Napretkova kulturno-historijska zbirka 1157/IV, Program zabave 15. 1. 1899. Na programu naziv društva Narodno glasbeno-pjevačko družtvo Hrvoje.

225 "Hrvojeva zabava", u: Osvit, br. 6, Mostar, 19. 1. 1899.

226 "Hrvojeve pokladne zabave", u: Osvit, br. 14, Mostar, 15. 2. 1899.

227 "Iz hrvatskog glas.-pjev. družtva Hrvoje", u: Osvit, br. 15, Mostar, 18. 2. 1899.

228 "Proslava otvorenja hrvatskog prosvjetnog zavoda" i "Hrvojeva zabava", u: Osvit, br. 26, Mostar, 29. 3. 1899.

229 "Hrvoje i Hrvatska dionička tiskara", u: Osvit, br. 25, Mostar, 26. 3. 1899.: "Družtvo Hrvoje je prvi kulturni zavod, koje goji milu hrvatsku pjesmu, širi zanos i ljubav za dom i hrvatski rod, prvo je i zvano, da se veseli i slavi zasnutak i potvrdu ovog novog, znamenitog hrvatskog kulturnog zavoda, koji imade plemenitu svrhu kao i Hrvoje, da opet goji i širi hrvatsku knjigu, promiče hrvatsku misao, štiti i brani interese naroda našega, jer je i osnovan na žuljevima naroda." Hrvojevac. 
hrvatska slava... A toj narodnoj stvari služiti će ovaj prosvjetni politički zavod, što ga je narod podigao, da mu bude jakom tvrdjom hrvatske misli i prosvjete, da mu bude čvrst i jak bedem u nastojanjima za velike narodne zadatke. A što se je taj bedem, ta tvrdja mogla podignuti, dokaz je kako je hrvatska sviest u narodu samomu jaka i budna, kako je spremna na rad i žrtve, radi česa joj se moraju pokloniti i oni, koji su do sada proti njoj - proti toj hrvatskoj sviesti i hrvatskim interesima - htjeli da pronose i provadjaju nenarodne misli i težnje, što se protive i narodnim pravima i poviesti i duši narodnoj."230 Ova proslava otvaranja Hrvatske dioničke tiskare 2. i 3. travnja 1899. u Mostaru bila je velika pobjeda hrvatske ideje i misli, a očitovala se i hrvatska uzajamnost. ${ }^{231}$

Ovaj veliki kulturni događaj u Mostaru nagovijestio je novo stoljeće u koje Hrvati ulaze na temeljima koje je izgradio Frano Milićević svojom tiskarom iz 1872. godine. Hrvatska dionička tiskara podići će kvalitetu tiska i moći odgovoriti na nove izazove koje novo stoljeće nameće. Kada promatramo povijest tiskarstva u Mostaru, ovo je zasigurno početak drugog razdoblja koje će se svakako označiti boljom tehničkom kvalitetom, ali i brojnim izdanjima koje stara tiskara nije mogla zadovoljiti.

Prilikom osnivanja Hrvatskog pjevačkoga i tamburaškoga družtva Vlašić u Travniku Hrvatsko glasbeno-pjevačko družtvo Hrvoje uputilo je brzojav: "Najmladjem drugu i bratu u radu za hrvatsku prosvjetu najsrdačnije čestita u veseli se Hrvoje."232

Hrvatsko glasbeno-pjevačko družtvo Hrvoje nastavlja sa svojim aktivnostima, sa sijelima i zabavama, a jedna od njih je organizirana 7. svibnja 1899. s uobičajenim programom i plesom..$^{233} \mathrm{Na}$ zabavi, koju je priredio $H G P D$ Hrvoje, među gostima se pojavio i slikar iz Češke g. Alois Kalvoda, ${ }^{234}$ koji je s velikim zanimanjem pratio zabavu, a posebno su ga oduševile mostarske Hrvatice u narodnoj nošnji, s kojima je i zaplesao. ${ }^{235}$ HGPD Hrvoje je organizirao ljetnu zabavu u kazališnoj dvorani doma Bratovštine koja je okupila veliki broj građana, a bio je priličan broj muhamedanaca unatoč činjenici što su odmori. Nazočan je i bihaćki podnačelnik Jozo Ivanko-

230 "Za hrvatsku stvar", u: Osvit, br. 27, Mostar, 1. 4. 1899.

231 "Hrvatska proslava", u: Osvit, br. 28, Mostar, 5. 4. 1899.

232 "Hrvoje Vlašiću", u: Osvit, br. 36, Mostar, 3. 5. 1899.

233 "Hrvojeva zabava", u: Osvit, br. 38, Mostar, 10. 5. 1899.

234 www. encyklopedie.brna.cz, Češki slikar 1875.-1934., završio Akademiju likovnih umjetnosti u Pragu 1897. godine. Slika impresionističke pejzaže (24. 3. 2016.).

235 "Češki slikar u družtvu Hrvoji", u: Osvit, br. 80, Mostar, 4. 10. 1899. 
vić. ${ }^{236} \mathrm{U}$ osvrtu na zabavu naglašava se njezin program u kome su nastupili Hrvojev pjevački zbor, koji je otpjevao koračnicu Danice. Mješoviti zbor Hrvata i Hrvatica pobudio je radost u građanstvu koje je nazočilo predstavi. U drugom dijelu s recitacijom nastupio je Petar Mikulić, a u dramskom programu Petar Soldo, Ivan Smoljan, Jelka Soldo, A. Halilović, R. Hrstić i M. Škrobić. ${ }^{237}$ Prije godišnje Glavne skupštine društva poslano je pismo u Osvit vezano za izbor novog odbora društva. Održavali su se dogovori i sastanci tko će biti izabran u odbor i voditi Hrvoje. Nadali su se izboru koji će biti na dobrobit društva: "Stoga složno na izbor. Pred pragom družtvene sgrade otresimo sve osonosti, stupimo u taj hram prosvjete s plemenitom nakanom, da našem Hrvoji koristimo, izaberimo ljude, koji će vješto i dostojno upravljati našim družtvom i čiji će rad biti koristan za Hrvatstvo, koji će osvjetlati obraz naš i društva."238 Uloga Hrvoja bila je da objedini sva hrvatska društva u zemlji u jedan savez i to bi bila kulturna pobjeda hrvatske misli u Bosni i Hercegovini. Jedan od osnivača Hrvoja bio je Blažko Zelenika, koji je rođen u Crnču 1828. godine, a umro u Mostaru 1899. godine. Surađivao je sa Šćepom Grabovcem, Nikom Fišićem, Vidom Šešeljom, Petrom Bašadurom i Ivanom Dunđom. Prijateljevao je s Mihovilom Pavlinovićem, a njegova kuća bila je otvorena svim Hrvatima. Od njega se biranim riječima na pokopu oprostio Marko Šešelj: "...i kao vrlog rodoljuba Hrvata, radi čega ćemu ostati vječan spomen u hrvatskom narodu, osobito medju mostarskim Hrvatima." 239

Nakon Skupštine koja je održana 15. listopada 1899. usvojena su izvješća o radu i financijama te izabran novi Odbor koji će rukovoditi društvom u narednoj godini. Umjesto izabranih članova, Šćepe Mihića i Blaža Merdže, izabrani su Stjepan Radulović i Petar Soldo. ${ }^{240}$ Tijekom godine Hrvoje je organizirao svaki mjesec jednu zabavu, a za 3. prosinca planirana je veća zabava za koju se marljivo pripremao. ${ }^{241}$ Glavna godišnja zabava održana je 3. prosinca 1899. s velikim i dobro osmišljenim programom. U dramskom programu igrali su: Smrt Matije Gubeca, Crna kraljicu $i$ Prokletstvo na Medvedgradu. Pjevački zbor je dao svoj doprinos izvodeći pojedine skladbe na zadovoljstvo publike. ${ }^{242}$ Hrvoje nastavlja sa sijelima, a

236 "Hrvojeva ljetna zabava", u: Osvit, br. 64, Mostar, 9. 9. 1899.

237 "Hrvojeva zabava", u: Osvit, br. 80, Mostar, 4. 10. 1899.

238 "U oči Hrvojeve skupštine", u: Osvit, br. 83, Mostar, 14. 10. 1899.

239 "Građani", u: Osvit, br. 72, Mostar, 6. 9. 1899.

240 "Iz družtva Hrvoje", u: Osvit, br. 85, Mostar, 21. 10. 1899.

241 "Hrvojeva zabava", u: Osvit, br. 95, Mostar, 23. 11. 1899.

242 "Hrvojeva zabava", u: Osvit, br. 98, Mostar, 6. 12. 1899. 
jedno je održano 17. prosinca 1899. Za doček Nove godine organizira već tradicionalnu zabavu za Silvestrovo. ${ }^{243}$

Nakon prve desetogodišnjice svoga rada Hrvoje hvata ritam zabava koje sada već tradicionalno organizira za različite prigode ili obilježavajući važne obljetnice. Jedna od zabava priredila se za Novu godinu 1900. bila je veoma dobro posjećena, a uz kulturni program bio je organiziran i ples. "Tako nam je i naš hrvatski Hrvoje, koji se može podičiti dvanaestogodišnjim blagotvornim radom za hrvatsku pjesmu i prosvjetu, priredio sbilja krasnu zabavu, koja je bila posjećena kao nikad prije. Dvorana je bila dupkom puna, te više nije bilo moguće dobiti mjesta, Hvala za to Hrvatima, koji shvaćaju što je naš Hrvoje i kakav mu je zadatak! ...A u Hrvoju poznamo samo članove njegove i Hrvate, stališ i položaj pojedinca je tu sporedan." ${ }^{244}$ Među članovima Hrvoja ima članova različitih zanimanja, obrazovanja kao i položaja unutar tadašnjeg društva, ali u radu to nije bilo presudno pa su se isticali oni s talentom kao i oni kojima je Hrvoje prirastao srcu. U svom govoru urednik Osvita Stjepan Radulović, koji se jezgrovito prisjetio hrvatske prošlosti, ističe: "A ove godine stupamo u novi viek, viek, u kojemu će Hrvatu oživjeti mile mu i svete uspomene njegove samostalnosti, kad no je pred hiljadu godine okrunjen prvi hrvatski kralj, komu nek je slava! Hrvat pravom očekuje, da mu se željeni ideali ostvare, a ispuniti će se, jer je uz nas Bog i Hrvati."245 Za Uskrs 1900. godine Hrvoje je priredio veliku zabavu 16. travnja koja je bila tradicionalno dobro posjećena, a svojom nazočnošću uveličali su je Hrvati iz Metkovića ${ }^{246} \mathrm{Hr}$ voje je bio u novom odijelu i ugodno je iznenadio programom. Posebno se istaknula gđica Milka Kovač koja je izvela Deželićevu pjesmu Bosanski odseljenik što je dobro primljeno od strane muslimana koji su nazočni zabavi, od kojih su neki došli iz Stoca. ${ }^{247}$ Kako bi u što većem broju mogli prisustvovati na slavlju Trebevića u Sarajevu, ${ }^{248}$ Hrvoje je organizirao zaba-

243 "Hrvojevo sielo i Silvestrovo u Hrvoji", u: Osvit, br. 102, Mostar, 20. 12. 1899.

244 "Još o Hrvojevoj silvestarskoj zabavi", u: Osvit, br. 2, Mostar, 10. 1. 1900.

245 Isto.

246 "Hrvojeva zabava", u: Osvit, br. 31, Mostar, 18. 4. 1900.

247 "Hrvojeva zabava", u: Osvit, br. 32, Mostar, 21. 4. 1900.

248 "Inštalacija zastave hrvatskoga Trebevića", u: Osvit, br. 36, Mostar, 5. 5. 1900. Hrvatsko pjevačko družtvo Trebević poslalo je svoj proglas sa rasporedom svečanosti 2. do 4. lipnja 1900. u Sarajevu. "Ovaj dogodjaj neće radi mnogih razloga biti samo privatna ceremonija našega družtva, nego će imati podpuno znamenje eminentne hrvatske narodne slave, jer će se evo razviti hrvatski barjak u Herceg-Bosni, da kao prvi javni hrvatski simbol okupi oko sebe sve Hrvate ovih zemalja bez razlike vjere, pak da ujedinjeni i vjerni Trebevićevu geslu: U jedinstvu naš je spas, pjesma će sjediniti nas!" 
vu da sakupi dovoljno novca za taj put. ${ }^{249}$ Prilikom povratka sa svečanosti u Sarajevu brojna društva iz Dalmacije posjetila su Mostar, ${ }^{250}$ a Hrvoje je bio domaćin. ${ }^{251}$ Hrvoje se i ovaj put iskazao kao dobar domaćin, ali i s priredbom u čast dragih gostiju na koje je bio ponosan zbog časti koju su mu ukazali svojim dolaskom u Mostar.

Jedan od predsjednika Hrvoja, fra Jerko Ljubić, umro je iznenada 1. lipnja 1900. u 43. godini života. Iskazao se u radu Hrvoja i uvijek nastojao istaknuti njegovo hrvatsko obilježje, a radio je i na razvoju prosvjete u Hercegovini. ${ }^{252}$ Krajem srpnja Hrvoje je priredio zabavu na otvorenom u bašči gostionice Petra Vasilja u spomen kralja Tomislava. Pjevački i glazbeni program okupio je dosta mostarskog građanstva, a sav prihod je darivan Hrvatskoj čitaonici u Duvnu. ${ }^{253}$ Ovakvim svojim postupcima mostarsko društvo je prednjačilo i bilo je putokaz ostalima kako treba nesebično pomagati hrvatska društva u Herceg-Bosni. Zabava koju je Hrvatsko glasbeno-pjevačko družtvo Hrvoje organiziralo u hrvatskom kazalištu doma Bratovštine 14. listopada 1900., uz glazbeni program, dat je igrokaz Razbojnici koji je pohrvatio Bogomir Brleković. ${ }^{254}$ Prilikom dolaska Hrvatskog kazališta iz Varaždina ponovno je domaćin bio Hrvoje koji je pomogao da se gosti predstave u što boljem svjetlu, a članica Hrvoja gđica Jelka Soldo igrala je jednu od ženskih uloga u Graničarima. ${ }^{255}$ Kako je došlo do promjene imena koje društvo nosi, Hrvatsko glasbeno pjevačko družtvo Hrvoje u Mostaru, upućena su i izmijenjena pravila na odobrenje koje su u ime društva potpisali predsjednik dr. Matej Milas i tajnik Ante Jukić 10. studenoga $1900 .{ }^{256}$

249 "Zabava našega Hrvoje", u: Osvit, br. 36, Mostar, 5. 5. 1900.

250 "Sielo u Hrvoji", u: Osvit, br. 45, Mostar, 13. 6. 1900.

251 "Gosti u Hrvoju", u: Osvit, br. 44, Mostar, 9. 6. 1900. U Mostaru su bili: iz Splita društva Napredka, Sokola, Vatrogasna i Jadranska vila, karlovačka društva Zora i Nada, Sokola iz Kostajnice, iz Makarske Gusle, Hrvatsko Makarsko-Primorske čitaonica i Hrvatski sokol, a gospoda Trumbić, Modrušan, F. Miler, dr. Smodlaka, dr. Bulić i ostali duže su boravili u Mostaru.

252 "Fra Jerko Ljubić", u: Osvit, br. 45, Mostar, 13. 6. 1900. Rodio se 13. 3. 1857. u Crnču, Široki Brijeg, a umro 1. 6. 1900. u Mostaru.

253 "Hrvoje u spomen duvanjske slave", u: Osvit, br. 57, Mostar, 23. 7. 1900.

254 ABiH Sarajvo, Napretkova kulturno-historijska zbirka 1158/IV, Pozivnica za zabavu 14. 10. 1900.

255 "Hrvojeva članica kao gostinja u hrv. dramatskom družtvu i Hrvatsko kazalište", u: Osvit, br. 84, Mostar, 27. 10. 1900.

256 ABiH Sarajevo, Napretkova kulturno-historijska zbirka 740/VI, Pravila Hrvatskog glasbenog pjevačkog družtva Hrvoje u Mostaru. Odobrena su 31. siječnja 1903., br. 13027/I ex 1903., Za poglavara zemaljske vlade: Odjelni predstojnik: HORMANN. 
Kako bi obilježili trinaestu godišnjicu svoga rada, HGPD Hrvoje je 6. listopada 1901. priredio veliku zabavu. Cilj društva je rad za hrvatsku prosvjetu i narodno osviještenje pa je rodoljubnom građanstvu Mostara ovom zabavom to zorno pokazao. ${ }^{257}$ Veliki članak posvećen je trinaestoj obljetnici osnutka HGPD-a Hrvoja u Mostaru u kojem se osvrće na prošlost: "Osnivači družtva imali su na umu, da koncetriraju sve, što hrvatski misli i osjeća u jednu skupinu, da mladež ujedini, da pjesmom razplamti vruću ljubav prema miloj hrvatskoj grudi, jednom riečju, da družtvo bude rasadnik hrvatske misli, ognjište hrvatske sviesti !"258 Društvo je njegovalo glazbu i pjesmu, ali je počelo i s amaterskim predstavama koje su bile dobro posjećene. U radu društva veliku ulogu je odigralo hrvatsko građanstvo, a jedan dio inteligencije nije ni moralno niti materijalno pomagao rad $\mathrm{Hr}$ voja. Društvu se želi puno uspjeha i napretka u njegovoj četrnaestoj godini rada. Aktivno učešće HGPD-a Hrvoja vidljivo je u proslavi obilježavanja pedesetgodišnjice redovništva biskupa fra Paškala Buconjića 14. listopada 1901. Tajnik Ante Jukić je u ime Hrvoja pozdravio biskupa koji je uvijek bio veliki zaštitnik i prijatelj društva koje služi hrvatskoj misli. ${ }^{259}$ Kako je Odboru HGPD-a Hrvoje izlazio mandat, organizirali su oproštajnu zabavu odstupajućeg Odbora 1. studenoga 1901. ${ }^{260}$ Nakon održane glavne skupštine HGPD-a Hrvoje 10. studenog 1901. izabrana je nova uprava koju su činili: predsjednik Adam Mikačić, tajnik Nikola M. Smoljan, blagajnik Ivan J. Smoljan, knjižničar Ivan P. Milićević, arhivar Marko Paradžik, odbornici: prof. Jamnicki, Urumović, Janković i o. fra Nikola Šimović revizori: prof. Bartol Inhof, prof. Lucian Popović zamjenici: Stjepan Škrobić i Nikola Krešić. Nisu primili čast fra Nikola Šimović i Bartol Inhof. ${ }^{261}$ U novoj upravi vidimo dosta profesora koji rade na ovdašnjoj gimnaziji, a uz njih su mostarski građani koji su obrtnici, trgovci ili posjednici. Početkom XX. stoljeća dosta stranaca dolazi i u Mostar i uključuje se u rad građanskih udruga. Krajem studenog Hrvoje za svoje članove organizira sijelo koje je dobro posjećeno. ${ }^{262}$ Glavna godišnja zabava održana je 8. prosinca 1901. u prostorijama Bratovštine s pučkim igrokazom Barun Franjo Trenk. ${ }^{263}$

257 "Sjajna Hrvojeva zabava", u: Osvit, br. 79, Mostar, 7. 10. 1901.; ABiH Sarajevo, Napretkova kulturno-historijska zbirka 1143/IV, Pozivnica za zabavu 6. 10. 1901.

258 "Hrvoje na pragu četrnaeste godine obstanka", u: Osvit, br. 81, Mostar, 17. 10. 1901.

259 "Biskupov jubiljej", u: Osvit, br. 82, Mostar, 21. 10. 1901.

260 ABiH Sarajevo, Napretkova kulturno-historijska zbirka 1144/IV, Oproštajna zabava 1. 11. 1901.

261 "Nova Hrvojeva uprava", u: Osvit, br. 86, Mostar, 14. 11. 1901.

262 "Hrvojevo sielo", u: Osvit, br. 88, Mostar, 27. 11. 1901.

263 ABiH Sarajevo, Napretkova kulturno-historijska zbirka 1145/IV, Zabava sa plesom 8. 12. 1901. 
Prilikom osamdesetog rođendana fra Grge Martića, ${ }^{264}$ najstarije Hrvatsko glasbeno-pjevačko družtvo Hrvoje u Bosni i Hercegovini, 19. siječnja proslavlja na dostojan način: "Preko tog znamenitog časa nije mogla kršna Hercegovina sa glavnim svojim gradom šutke preći, a da se ne ogrieši o vječnu harnost svome velikom sinu, koji je prvo svjetlo u njoj ugledao: ne može ni Bosna ni cielo Hrvatstvo ostati mirno." 265 Sijelo koje je organizirao Hrvoje bilo je posvećeno fra Grgi Martiću. Ante Jukić je govorio o njegovu životu i radu, a pjesmu u čast Martića, od Veljka Obradova, deklamirala je Jelka Soldo. Vrhunac svečanost je bio kada na spomeniku sjedi pjesnik i drži knjigu, a oko njega stoje vile: Hrvatica, Hercegovka, Dalmatinka i sva u crnini Istranka. Ovoj svečanosti su nazočni ugledni građani Mostara kao i veliki broj franjevaca na čelu s provincijalom fra Augustinom Zubcem. ${ }^{266}$ Neumoran rad na organiziranju zabavnih večeri s plesom nastavljen je nakon Uskrsa. Tako je 4. svibnja 1902. u hrvatskom kazalištu doma Bratovštine organizirana zabava. ${ }^{267}$ Koliko su članovi Hrvoja bili povezani, ali i uvažavani od ostalih hrvatskih društava, govori i podatak da su prilikom svatova tajnika Nikole Smoljana s Hrvaticom iz Livna Ankom Tadić sudjelovanje uzela društva Dinara $i$ Trebižat. Zanimljiv je put do Livna koji je išao željeznicom do Blažuja, a dalje preko Kiseljaka, Busovače, Travnika, D. Vakufa, Bugojna, Kupresa u Livno. U povratku, nakon dočeka i ispraćaja u Livnu gdje se posebno hrvatskom pjesmom i glazbom istaklo društvo Hrvatska Dinara, vraćaju se preko Županjca, Posušja i Ljubuškog. U Ljubuškom su drage goste dočekali članovi hrvatske čitaonice i Trebižata kako bi se zahvalili $\mathrm{Hr}$ voju na velikoj i nesebičnoj pomoći koju im pruža. Na ulazu u Mostar svatove je dočekao veliki broj građanstva, a Stjepan Radulović srdačnom dobrodošlicom. ${ }^{268}$ Članovi Hrvoja izgubili su jednog od osnivača društva Ivana Bašadura, koji je umro 15. rujna 1902. ${ }^{269} \mathrm{U}$ ime hrvatskih društava, a napose Hrvoja, od pokojnika se biranim riječima oprostio Stjepan Radulović. Hrvati u Mostaru su 14. rujna 1902. utemeljili Hrvatsko potporno društvo za potrebne dake srednjih $i$ visokih škola iz Bosne $i$

264 ABiH Sarajevo, Napretkova kulturno-historijska zbirka 2558/IV, Sjajno Martićevo sijelo 19. 1. 1902.

265 "Martićeva proslava", u: Osvit, br. 6 i 7, Mostar, 23. 1. 1902.

266 Isto.

267 ABiH Sarajevo, Napretkova kulturno-historijska zbirka 1146/IV, Zabavna večer 4. 5. 1902.

268 "Hrvatski svatovi", u: Osvit, br. 43, Mostar, 29. 5. 1902.

269 "Hrvatsko glasbeno-pjevačko družtvo Hrvoje u Mostaru", u: Osvit, br. 73, Mostar, 17. 9. 1902. 
Hercegovine. ${ }^{270}$ Ono se ujedinjava s Hrvatskim društvom Napredak - za potpomaganje naučnika i đaka Hrvata-katolika Sarajevo 9. lipnja 1907. u Hrvatsko kulturno društvo Napredak sa sjedištem u Sarajevu. ${ }^{271}$

Ovo je bila dosta uspješna godina u kojoj je organizirano 10 zabava što je u svojoj XIV. društvenoj godini djelovanja svakako značajan broj..$^{272}$ Početkom 1903. godine organizirana je zabava s plesom u domu Bratovštine, a izvedena je drama Ive Vojnovića Ekvinocij, što je bila novina na repertoaru Hrvoja. ${ }^{273}$ Hrvoje organizira sijela kako bi društvenom tombolom sakupio novac za nesmetan rad, a na ta okupljanja djeca bez roditelja nisu smjela

270 "Konstituirajuća skupština hrvatskog podpornog družtva za potrebne djake srednjih i visokih škola iz Bosne i Hercegovine", u: Osvit, br. 17, Mostar, 17. 9. 1902. Predsjednik fra Radoslav Glavaš, potpredsjednik veleposjednik i trgovac Martin Čule, tajnik prof. B. Inhof, tajnik II. učitelj Ante Jukić, blagajnik prof. Lav Jamnicki, podblagajnik trgovac i posjednik Blaž Merdžo, Odbornici: trgovac i veleposjednik Ilija Ivanković, trgovac i posjednik Petar Smoljan, učitelj Kosta Urumović, posjednik i srebrodjelac Mato Smoljan, sudski prislušnik Janko Ašperger i poduzetnik i posjednik Toma Kovač. "Hrvatsko podporno družtvo za potrebne djake", u: Osvit, br. 77, Mostar, 31. 9. 1902. Utemeljitelji su: posjednik i bravar Ančić Petar N., biskup Buconjić Paškal, trgovac i posjednik Bašadur Ivan (umro), posjednici braća Bebek, veleposjednik iz Janjine Bjelovučić Zvonimir, mjernik Brozović Joso, posjednik Batun Muhamed Hilmi ef., posjednik Martin Čule, gim. Prof. Jamnicki Leo, župnik Knezović Pijo, posjednik Kovač Toma, pravnik Kurt mehmed Dželaludin, posjednik Kurtaga Petar, trgovac Kvesić Vid, magaziner želj. Maršalek Josip, trgovac Merdžo Blaž, trgovac Merdžo Mijat, ljekarnik Mikan Vjekoslav, trgovac Mikačić Adam, trgovac, Čapljina Mrčić Ivan, gostioničar Greč Frano, biskupski tajnik Ostojić Dujam, Samostan čč. O. Franjevaca Mostar, trgovac i posjednik Smoljan Ivan, posjednik i sredbodjelac Smoljan Mato, trgovac Smoljan Jure st., trgovac Smoljan Stjepan, trgovac Smoljan Petar, gostioničar Stojčić Nikola, srebrodjelci braća Šiljeg, gim. Učitelj Urumović Kosta, Uredništvo Osvita, Uredništvo Kršćanske obitelji, financijski oficijal Vrban Josip. Ukupno 34 člana. Podupirajući članovi I. reda ukupno 66; Podupirajući članovi II. reda 24; Podupirajući članovi III. reda 10. Veliki broj članova su ujedno i članovi Hrvoje pa je i na taj način ovo društvo dalo svoj doprinos u pomaganju i školovanju siromašnih đaka.

271 ABiH Sarajevo, Napretkova kulturno-historijska zbirka, IV/1 i IV/3 br. 919. Hrvatsko potporno društvo Napredak glavna podružnica u Mostaru; PetAR ČUle, Napredak u Mostaru, rukopis str. 9, napisan 30. jula 1925.; Mijo PolJaK, Hrvatsko kulturno društvo Napredak, Predavanje o njegovom postanku, cilju i radu i o našim dužnostima prema njemu br. 2043 IV/3.(Preštampano iz Požeških novina), 28.

272 ABiH Sarajevo, Napretkova kulturno-historijska zbirka 1147/IV, Zabava sa plesom 5. 10. 1902.

273 ABiH Sarajevo, Napretkova kulturno-historijska zbirka 1148/IV, Zabava sa plesom 6. 1. 1903. 
dolaziti. ${ }^{274}$ Koliko je rad HGPD-a Hrvoje bio posvećen hrvatskoj ideji i razvoju hrvatskih društava vidi se iz odnosa prema novom društvu Sokol u Mostaru. Hrvoje je posjetio ples Sokola, a to je ovaj uzvratio došavši u sokolaškim odijelima na Hrvojevu zabavu. Osvit pozdravlja ovaj čin bratske suradnje i želi da oba društva napreduju. ${ }^{275}$ Veliku pažnju posvećuje razvoju čitaonica i hrvatskih pjevačkih društava po Herceg-Bosni, a radi i na osnivanju saveza, unatoč činjenici da su pojedina društva članovi $S a$ veza hrvatskih pjevačkih društava u Zagrebu. Potrebno je napraviti i savez unutar Herceg-Bosne, a taj zadatak bi trebalo preuzeti najstarije društvo, a to je HGPD Hrvoje. ${ }^{276}$

Velika pozornost dana je 800. obljetnici smrti Petra Svačića, a pozivaju se svi predsjednici i tajnici hrvatskih društava da na Uskrs dođu u Mostar radi temeljitijeg i zajedničkog rada društava. ${ }^{277}$ Osvit u svom uvodniku br. 27, od 4. travnja 1903. pod naslovom "Za složan i jedinstven rad" ponovno naglašava značaj zajedničkog rada koji bi na taj način povećao broj društava i čitaonica te podigao kvalitetu njihova rada.

Koturaško-gombalačko družtvo Sokol u Mostaru ${ }^{278}$ organiziralo je izlet u Metković 19. travnja 1903. U Metkoviću su članovi Hrvatske neretvanske čitaonice priredili srdačan doček s pjesmom i glazbom. Nakon objeda i razgledanja grada gosti iz Mostara su svečano ispraćeni na vlak uz hrvatsku pjesmu i glazbu. ${ }^{279}$ Prilikom podizanja spomenika dr. Anti Strčeviću u Šestinama izaslanstvo HGPD-a Hrvoje položilo je vijenac na grob hrvatskog velikana. ${ }^{280}$ Tijekom priprema za godišnju skupštinu upućena je kritika nekim odbornicima i članovima koji nisu izvršavali

274 "Hrvojevo sijelo", u: Osvit, br. 13, Mostar, 14. 2. 1903.; i u br. 22, 18. 3. 1903. "Naša družtva stvorena su, kako smo često puta naglasili, da rade i služe probudjenju hrvatske narodne sviesti i širenju prave prosvjete, uljudbe i snošljivosti, te tako da čine neki prijelaz iz starog obiteljskog i družtvenog života u novi, bolji i napredniji, koji odgovara duhu ovog prosvjetnoga vieka, koji utire put hrv. narodnoj misli, u kojoj nalazimo sreću ovoga naroda." Ponovo se potencira stvaranje saveza kako bi se društveni rad unaprijedio i razgranao.

275 "Hrvoje i Sokol", u: Osvit, br. 16, Mostar, 25. 2. 1903.

276 "Uvaženja vriedan predlog", u: Osvit, br. 20, Mostar, 11. 3. 1903.

277 "Svim hrvats. pjevačkim i sokolaškim družtvima, kao i hrvatskim čitaonicama u Herceg-Bosni hrvatski pozdrav !", u: Osvit, br. 26, Mostar, 1. 4. 1903.

278 Biciklističko i gimnastičko društvo op. T. Z.

279 "Mostarski Sokol u Metkovićima", u: Osvit, br. 32, Mostar, 22. 4. 1903.

280 "Mostar k Starčevića slavlju", u: Osvit, br. 81, Mostar, 10. 10. 1903. 
svoje obveze te na taj način dovode i sam rad društva u pitanje. Uz moralni rad treba raditi i na materijalnom uzdizanju društva i postaviti pitanje izgradnje društvenog doma. ${ }^{281}$

U svom prvom broju od 6. siječnja 1904. Osvit je čestitao i zaželio puno uspjeha u novoj godini svim hrvatskim društvima širom Herceg-Bosne. Započeta je akcija sakupljanja priloga za posvećenje barjaka i na prijed$\log$ dične Hrvatice Katarine Domjan sakupljeno je 4 krune. ${ }^{282}$ Hrvoje je 17. siječnja 1904. priredio sijelo za svoje posjetitelje s glazbenim i dramskim programom, a i 2 . veljače organiziran je sličan program. ${ }^{283}$

Za Uskrs, u domu Bratovštine, priređena je zabava s plesom i glazbom pješačke pukovnije. Ulaznice su se mogle kupiti u trgovini Petra i Nikole Smoljana. Nastupilo je niz članova Hrvoja, a u dramskom programu izvedeno je Zimsko sunce Viktora Cara Emina, u kojem je oslikana borba hrvatskog naroda u Istri protiv nametanja tuđinskih ideja. ${ }^{284} \mathrm{Iz}$ broja $\mathrm{u}$ broj Osvit donosi dopise o pripremama za instalaciju zastave Hrvoja, a u br. 24 , 26. ožujka 1904., donosi popis onih koji su na izletu u Ilijiće dali dobrovoljni prilog za tu svečanost.

Osvit u tekstu "Zastava hrvatskog pjevačkoga družtva Hrvoje u Mostaru", br. 26, od 2. travnja 1904. prenosi pisanje Hrvatskog prava iz Zagreba: "Ovih dana bila je izložena u Ilici u Bothovom izlogu vanredno liepa zastava, koja je privlačila svojom orginalnošću izradbe prolazeće obćinstvo, te je postajalo pred izlogom i motrilo ju. Zastava je to, što ju Hrvatice Starčevićanke poklanjaju hrvat. družtvu Hrvoju u Mostaru u kršnoj Hercegovini. Zastava je građena u tri piohe: crvena, biela i modra; na bieloj u sredini stoji grb Hrvatske, a sve tri plohe izvezene su samim hrvatskim ornamentima... Za tu zastavu izradio je nacrte poznati naš majstor narodnih motiva g. August Posilović, a izvezena je u njegovoj kući. S tim ponodnim hrvatskim stiegom šalju naše Starćevićanke dičnom Hrvoji i sjejnu uvezanu spomenknjigu, koju je takodjer izradio gosp. Posilović u narodnim motivima, na kojoj se nalazi posveta družtvu, te podpisi... Pod ovom zastavom živilo, raslo cvalo hrvatsko društvo Hrvoje u Mostaru. Zastava je stigla u Mostar, te je pohranjena u družtvu."285 Ovo je samo

281 "Iskrena rieč pred skupštinu Hrvoje", u: Osvit, br. 82, Mostar, 14. 10. 1903.

282 "Za inštalaciju Hrvojevog barjaka", u: Osvit, br. 2, Mostar, 9. 1. 1904.

283 "Iz družtva Hrvoje", u: Osvit, br. 5, Mostar, 20. 1. 1904.

284 "Hrvojeva zabava", u: Osvit, br. 24, Mostar, 26. 3. 1904.

285 "Zastava hrvatskoga pjevačkoga družtva Hrvoje u Mostaru", u: Osvit, br. 26, Mostar, 2. 4. 1904. i u br. 39, 18. 5. 1904., Barjak hrv. družtva Hrvoje u Mostaru prenose tekst iz Hrvatske Zastave. 
jedan od primjera što je Hrvoje značio za Mostar i Hercegovinu, ali je i njegova reputacija u Zagrebu bila na zavidnoj razini. Sve je to stečeno mukotrpnim radom s puno odricanja i entuzijazma članova društva te vizije onih koji su osnovali i vodili ovo društvo u proteklom razdoblju. Zborovođa društva, gospodin August Remec, odlikovan je od strane Saveza hrvatskih pjevačkih društava počasnom nagradom. ${ }^{286}$

Preko Osvita obavještavaju se članovi Hrvatskog glasbenog družtva Hrvoje da je sazvana izvanredna skupština društva 17. travnja 1904. u prostorijama Bratovštine u 14 sati. Dnevni red:

1). Izvještaj o uspjehu pregovora sa Bratovštinom sv. Ante u pogledu druš. kirije

2). Sdogovor o svetčanosti družtvene zastave

3). Eventualija u obsegu 16. društvenih pravila.

Nakon održane izvanredne skupštine Hrvatskog glasb.-pjevačkog družtva Hrvoje u prostorijama Bratovštine ${ }^{287}$ 17. travnja 1904. sklopljen je novi povoljniji ugovor s Bratovštinom sv. Ante oko iznajmljivanja prostorija za potrebe Hrvoja pa je stari ugovor iz 1897. zamijenjen novim iz 1904. godine. Najamnina je manja, a Hrvojev dug Bratovštini pripisan je kao prilog Hrvoju o čemu je izvijestio blagajnik Nikola Smoljan. O pripremama za instalaciju zastave izvijestio je Ante Jukić i izabran je Svečani odbor koji će imati sedam pododbora. Za počasnog člana izabrana je gospođa Marija Kumičić, koja je pribavila barjak za Hrvoja. ${ }^{288}$

Društvo je provodilo velike pripreme za svoju svečanost, kako u organizacijskom, tako i materijalnom pogledu sakupljajući sredstva za taj značajan događaj. Nastavlja se suradnja s društvima iz Dalmacije i Zagreba. U goste dolazi i Kolo iz Zagreba, koje je bilo na svečanosti Gundulića u Dubrovniku. Zajednički koncert organiziran je 24. svibnja 1904. u hrvatskom kazalištu doma Bratovštine sv. Ante u Mostaru. ${ }^{289} \mathrm{U}$ ime Hrvoja na svečanosti

286 "Hrvojev sborovodja gosp. August Remec", u: Osvit, br. 26, Mostar, 2. 4. 1904., angažiran je bio i na obljetnici Hrvatske neretvanske čitaonice u Metkoviću što mu je bilo još jedno priznanje.

287 ABiH Sarajevo, Napretkova kulturno-historijska zbirka 58/IV, Bratovština Sv. Ante u Mostaru Slavnoj Upravi Hrvat. Glasb. Pjev. Društva Hrvoje, 7. 7. 1899. Bratovština traži objašnjenje zašto se krši Ugovor iz 1897. godine kojim se iznajmljuje prostor Hrvoji.

288 "Hrvojeva izvanredna skupština", u: Osvit, br. 33, Mostar, 27. 4. 1904. Žena književnika Eugena Kumičića. Rođena Maršić u Varaždinu 1863. bavila se književnim, karitativnim i socijalnim radom. Vidi: Znameniti i zaslužni Hrvati te pomena vrijedna lica u hrvatskoj povijesti od 925.-1925., str. 154.

289 "Koncert Kola i Hrvoja", u: Osvit, br. 39, Mostar, 18. 5. 1904. 
Gundulića bilo je nazočno deset izaslanika. ${ }^{290}$ Sam koncert, u izvođenju dva hrvatska društva, ušao je u anale i upisan zlatnim slovima. ${ }^{291}$ Ovo je bio velik događaj za Hrvate u Mostaru jer su mogli vidjeti Kolo iz Zagreba, koje je proslavilo četrdesetogodišnjicu svog rada i bilo je uzor ostalim hrvatskim društvima tako da je zajednički koncert dao Hrvoju novu energiju i bio putokaz za budući rad. Brzojavi su stigli iz Trebinja: "Današnji zagrljaj Kola i Hrvoja bio na diku našoj Herceg-Bosni. U jedinstvu naš je spas, pjesma će sjediniti nas. Članovi Slavulja. Zanimljiv je bio i brzojav iz Dugogsela: Hrvatski pozdrav kršnim junacima Hrvoje i zagrebačkim Kolašima! Hrvatska čitaonica."292

Osvit u uvodniku br. 48, od 18. lipnja 1904. "Slava razvijanja Hrvojevog barjaka" donosi veliki tekst u tu čast: "U našem kamenitom Mostaru, gdje je mnoga dobra iskra frcnula za narodno hrvatsko osvještenje, idemo u susret radosnom času. Najstarije hrvatsko pjev. držtvo Hrvoje, koje je i u dobru i u zlu najodanije i najvjernije tražilo utjehe, okriepe i pobude pod svetim, slavnim i ponosnim trobojnim stiegom, što su nam ga pradjedovi potocima krvi branili i neoskrvnjena sačuvali i u amanet predali, Hrvoje, koji je svagdje bio prvo, kad se radilo o slavi hrv. imena i veličanju hrvatske pjesme, $s$ kojom nam se budi narodna sviest, a podiže hrvatski rodoljubni osjećaj-žudno se sprema davno očekivanom danu, kada će javno, svjestno i ponosno u prisustvu hrvatske braće iz svih sedam hrvatskih banovina, sastavnih dielova Tomislavove kraljevine, kojoj je kolievka ova gruda, razviti taj stieg i visoko ga dignuti nebu pod oblake, da se vidi, da se zna, da nas ima još Hrvata, da će nas biti, dokle i kaplje krvi naših predja u nama teče, dokle traje uspomena na našu slavnu prošlost, burnu i mukotrpnu sadašnjost, ali, dok je Boga i pravde, i nade na bolju i pravedniju budućnost." Autor članka osvrće se na instalaciju barjaka Trebevića kao i dar od Marije Kumičić i gospođa iz Zagreba koji je sada u Mostaru. Naglašava se uloga pjevačkih društava u buđenju hrvatske svijesti u Herceg-Bosni: "U budjenju hrvatske sviesti u našoj miloj Herceg-Bosni najvažniju su ulogu igrala naša pjevačka družtva, koja su milozvukom hrvatske pjesme budilice trgnula narod iz stoljetnoga sna, da ustane, da bude svoj na svome, da bude Hrvat-Pjevačka družtva u Herceg-Bosni bijahu pravi razsadnik hrvatske misli, bijahu ognjišta hrvatskih ideja za dobrobit našeg naroda, bijahu središte, gdje se sakupljaju svi, što hrvatski misle i osjećaju.

290 "Na Gundulićevu svetčanost barjaka", u: Osvit, br. 39, Mostar, 18. 5. 1904.

291 "Koncert Kola i Hrvoja", u: Osvit, br. 40 i 41, Mostar, 28. 5. 1904.

292 "Pozdravi Kolu i Hrvoji u Mostaru", u: Osvit, br. 41 i 42, Mostar, 28. 5. 1904. 
A najstariji borac, prvi, koji je razvio zastavu borbe za sveto hrvat. ime bijaše naš Hrvoje, koji je prije 16 godina na obali mutne Neretve ispod krševitog Veleža zapjevao gromornu pjesmu:

Hrvatska se Bosna diže,

Ljepša zora sviće njoj,

U kolo se, braćo, bliže,

Sad je Hrvat u svom svoj!"293

Ovo su nastavila ostala društva, a u prvom redu Slavulj $i$ Trebević koji su puno učinili na narodnom polju buđenja svijesti. Pozivaju se na svečanost u kršni Mostar od 13. do 15. kolovoza 1904. kako bi ova svečanost bila veličanstvena, što je Hrvoje svojim radom i zaslužio.

Prilikom organiziranja zabava primijećeno je da je slabiji odziv domaće inteligencije, a krivnja je na obje strane: "Zadaća pjevačkih družtava nije svoje zabave i koncerte poput kakvog pazara reklamirati, nego valja kod ljudi na sgodan način pobuditi interes za stvar. Jedno pjevačko i diletantsko družtvo ne smije biti kakvo mehaničko kazalište ili skladište fonografa, već mora da bude kulturni zavod, komu je zadaća gojiti liepu hrvatsku pjesmu, njom hraniti i odgajati svoj narod i buditi hrvatsku svijest."294 Iako su pripreme za veliku svečanost u tijeku, HGPD Hrvoje nastavlja sa svojim zabavama i jednu organizira u svojoj bašči 19. lipnja 1904. uza sudjelovanje vojne glazbe. ${ }^{295}$

Nisu svi blagonaklono gledali na rad Hrvoja i svečanost koja je pripremana pa je došlo do polemike s Narodnom hrvatskom strankom u Dalmaciji povodom jednog natpisa u glasilu Jedinstvo, koje je napalo svečanost i instalaciju barjaka. Odbacuje se svaki politički cilj posvete, jer je to proslava hrvatske zastave i onoga što je Hrvoje u proteklih 16 godina uradio na kulturnom polju. U potpisu, Odbor hrvatskog pjevačkog družtva Hrvoje. ${ }^{296}$ Ovo ipak nije zapriječilo da ostale novine, pa i one koje se bave književnošću, ovaj proglas sa simpatijama poprate i donesu u svojim tiskovinama. Doznajemo da iz Siska na proslavu dolazi osam članova Sloge: "...da posjete kršnu Herceg-Bosnu i pozdrave tamošnju našu junačku braću. Sveta

293 "Slava razvijanja Hrvojevog barjaka", u: Osvit, br. 48, Mostar, 18. 6. 1904.

294 "Hrvoje pred svetčanost", u: Osvit, br. 48, Mostar, 18. 6. 1904.

295 "Hrvojeva zabava", u: Osvit, br. 48, Mostar, 18. 6. 1904.

296 "Hrvojeva izjava predsjedničtvu hrvatske narodne stranke u Dalmaciji", u: Osvit, br. 54, Mostar, 9. 7. 1904. U potpisu su navedeni: predsjednik Petar N. Ančić, potpredsjednik Ante Jukić, tajnik M. Glavina, blagajnik Nikol M. Smoljan, knjižničar Grgo Smoljan, arhivar Josip Šiponi, odbornici: Marko Šiljeg, Stjepan Smoljan, Ivan Slišković i A. Remec. 
je to dužnost, da se s našom braćom što više upoznamo, da im junačku desnicu stisnemo, te ih tako bodrimo na daljni rad za slobodu mile nam zajedničke domovine Hrvatske." ${ }^{297}$ Stalno dobivamo izvješća u Osvitu o onima koji novčano svojim prilozima daju potporu ovoj svehrvatskoj svečanosti u gradu na Neretvi pokazujući tako što je Hrvoje značio i znači za Hrvate u Herceg-Bosni. ${ }^{298}$

Protiv pisanja Jedinstva javljaju se prosvjedom razna društva iz HercegBosne, a jedan od prosvjeda je i od livanjskih Hrvata. ${ }^{299}$ Prosvjed je upućen zbog pisanja i tretmana Hrvata u Herceg-Bosni u čemu prednjači urednik Jedinstva u Splitu Antonio Stražičić, koji ide tako daleko da ove prostore naziva srpskim zemljama zbog čega izaziva ogorčenje kod Hrvata koji tu žive od doseljenja. ${ }^{300}$ Ovako žestok odgovor na pisanje splitskog Jedinstva i ponašanje njegovog urednika samo su potvrda koliko je hrvatska narodna svijest ojačala i da s Hrvatima Herceg-Bosne suosjećaju Hrvati iz drugih hrvatskih zemalja, a uvijek se nađe onih koji su protiv narodne ideje.

Osvit u dvobroju 61 i 62 od 6. kolovoza 1904. na dvije stranice donosi proglas Svečanog odbora Hrvoja koji poziva: Gradjani Hrvati! Da u dane svečanosti okitite svoje kuće i dućane hrvatskom trobojnicom i aktivno učestvuju u svim točkama svečanosti 13., 14. i 15. kolovoza 1904. godine.

Zatim donosi precizan raspored svečanosti koju mogu svi nabaviti u trgovinama N. M. Smoljana i J. Smoljana. ${ }^{301}$ Najavljen je dolazak brojnih

297 "K Hrvojevoj slavi barjaka", u: Osvit, br. 55, Mostar, 13. 7. 1904.

298 "Za Hrvojevu slavu barjaka", u: Osvit, br. 54, Mostar, 9. 7. 1904. "Gvardijan na Šrokom Brijegu fra Stanko Kraljević je sakupio 71 krunu za proslavu, a darovatelji su: Franjevački samostan K 20, obitelj Milković K 10, po 5 K: A. Trstenjak i I. Likić; po 3 K Jozo Penavić po 2 K: M. Škobić, M. Slišković, M. Zeljko, A. Šušak i B. Bubalo po 1 K; Naglić, Drakulić, Trtanj, Horak, I. Milković, M. Perić, M. Softa, C. Naletilić, A. Marušić, Franetić, A. Prskalo, I. Kovačić, I. Marušić, I. Penavić, I. Zovko, I. Jelić, I. Pinjuh i jedno ime nečitljivo."

299 "Prosvjed livanjskih Hrvata proti pisanja Jedinstva", u: Osvit, br. 56, Mostar, 16. 7. 1904.

300 "Izjave protiv pisanja Jedinstva", u: Osvit, br. 57 i 58, Mostar, 23. 7. 1904. Potpisnici su: Vlašić Travnik predsjednik Stanko Šalković, Bosanski Novi Odbor hrvatske čitaonice predsjednik B. šulentić i potpredsjednik župnik Jure Pelivanović, Bosanski Brod Hrvatska narodna čitaonica, Konjic Hrvatska čitaonica potpisao čitav Odbor hrvatske čitaonice, Sarajevo Trebević predsjednik M. Bitić i tajnik J. Udovičić, Dubrovnik Gundulić. U narednom broju Osvita br. 61 i 62, Mostar, 6. 8. 1904.; "Dopisi": Nikole Zvonimira Bjelovučića iz Janjine na Pelješcu, Županjca 24 potpisa, Dervente Hrvatska čitaonica, Jajca Odbor hrv. pjev. i tamb. družtva Tomašević u Jajcu.

301 ABiH Sarajevo, Napretkova kulturno-historijska zbirka 481/IV, Raspored svetčanosti pri inštalaciji Hrvojeve zastave dne 13., 14. i 15. kolovoza 1904. 
hrvatskih pjevačkih i akademskih društava na Hrvojevu proslavu u Mostaru: "Slavulj Trebinje, Merkur Zagreb, Zvono Križevci, Davor S. Brod, Trebević Sarajevo, Vlašić Travnik, Lipa Osiek, Gundulić, Hrvatska zadruga i Česka Beseda Dubrovnik, Hrvat Brčka, Čitaonica Konjic, Graničar Nova Gradiška, Vienac Požega, Hrv. čitaonica Bugojno, Duvno i Dolac, Sljeme Šestine, Sloga i Danica Sisak, Podravac Koprivnica, Dinara Livno, Krajišnik Bihać, Zmaj od Bosne Beč, Majevica D. Tuzla, Tvrtko klub sveuč. gradjana Zagreb, Zviezda Vareš i Vienac Varaždin."302

Nakon što je svečanost instalacije društvenog barjaka održana, Osvit je na naslovnici uokvirenoj hrvatskom trobojnicom donio uvodnik: "Prava narodna manifestacija za hrvatsku misao". ${ }^{303}$

"Jedna od najvelebnijih slava hrvatskoga naroda bijaše svakako i ova u Mostaru. - Tu je narodna rieč imala prvenstvo, tu je narod progovorio sam svojom riečju, bez da je i od kog bio upućen, nego je vlastitom inicijativom odkrio svoju dušu, nadkrio svoje osjećaje i pokazao, da zna i hoće samo hrvatski osjećati.

Ova proslava pokazala je, da u Hercegovini živi jedan jedinstven narod, narod hrvatski, i da su zalud sve spletke naših protivnika i sluga tudjih ideja, da izbrišu sa tla Hercegovine Hrvatstvo, jer je ovo ukorienjeno i ustaljeno u duši hrvatskog naroda.

Svi posjetnici ove krasne hrvatske slave upoznali su, da u Hercegovini živi narod, koji je zadojen mislima i osjećajima hrvatskim, da taj narod shvaća onu težku borbu za obstanak imena hrvatskog i da taj narod mora jedan put pobijediti, mora doći svom žudjenom cilju. ..

Ono sudjelovanje seljačtva i gradjanstva, ono oduševljeno klicanje i zanosno osjećanje sveukupnog naroda pokazuje veliku moralnu snagu našeg naroda, pokazuje, da naš narod hoće da živi svojim životom, hoće da bude svoj u svom...

Baš ova svetčanost, koja je priredjena od hrvatskog Hrvoje, pokazuje, da hrvatska misao nije importirana u Herceg-Bosnu, nego da ta misao od vjekova živi, od vjekova u srdcima našeg naroda, i da je ta misao jedina historijska prirodna u ovim zemljama! Hiljadu gorkih izkustava dokazalo nam je, da se hrvatski narod do sada mnogo pouzdavao u druge, da je svoju snagu za druge žrtvovao, ali ovom slavom dokazao

302 "Hrvatska pjevačka družtva na slavi Hrvojevoj", u: Osvit, br. 61 i 62, Mostar, 6. 8. 1904.

303 "Prava narodna manifestacija za hrvatsku misao", u: Osvit, br. 65 i 66, Mostar, 20. 8. 1904. 
je narod, da hoće, da služi samo sebi, da hoće da služi samo hrvatskoj misli! - I hoće, ne treba ničije pomoći, nego pomoći Boga i Hrvata, pa će biti Hrvatska Hrvatom!"

U drugom tekstu "Hrvatsko narodno slavlje u Mostaru": "Liepi naš i mili Mostar grad, u kojem je u novijoj eri hrvatskoj našeg preporoda u Herceg-Bosni, da tako rečemo, prvi put frcnula jaka i nikad više neugasiva iskra hrvatske sviesti i oživjele prošlosti hrvatske, te silnom, jer prirodnom, snagom zahvatila čili i kršni hercegovački narod, koji je u ogromnoj većini ostao vjeran slavnoj svojoj prošlosti hrvatskoj i uzčuvao nezaboravnu uspomenu na velikane svoje..."304 naglašena je uloga Mostara i Hercegovine za preporodna gibanja i početak procesa koji se širi na druge krajeve zemlje.

Uvodničar Osvita je u ovom tekstu naglasio što je Hrvoje i ova svečanost u Mostaru značila za Hrvate u Herceg-Bosni te put kojim treba ići u ostvarenju narodnog cilja. Sama svečanost pokazala je koliki ugled uživa $H G P D$ Hrvoje među ostalim društvima u drugim hrvatskim zemljama. Savez pjevačkih društava odao mu je priznanje održavši redovitu skupštinu u Mostaru za vrijeme svečanosti. Sljedeće dvije stranice posvećene su svečanosti pod naslovom "Hrvatsko slavlje u Mostaru". Donosi se i osvrt na pripreme i događaje 13. kolovoza 1904. kada su posebno bili iznenađeni dolaskom seljaka iz Ravna s velečasnim don Marijanom Vujinovićem, a na grudima im stoji hrvatska trobojnica s natpisom Hrvatska čitaonica $u$ Ravnu. S njima je došao veći broj izaslanika iz okolnih mjesta. Svečanosti je nazočno ukupno 49 društava što govori o ugledu i značaju slavljenika. Pjesnik Nikola Ostojić spjevao je prigodnu pjesmu Pred Hrvojevom zastavom, a Ivan Trtanj Na vrelu Vrbasa. Pjesme su obojene hrvatskim narodnim zanosom.

Djelovanje Hrvatskog glazbenog pjevačkog društva Hrvoje u Mostaru kroz proteklih 16 godina nije prošlo nezapaženo ni Savezu hrvatskih pjevačkih društava koje je iskoristilo ovu prigodu i odlikovalo članove Hrvoja za desetogodišnji rad: Jelku Soldo i Ružu Hristić te Petra Soldu, Stjepana Mihića, Ivana Kurtovića, Pavu Pavkovića, Josipa Šiponija, Petra Šiljega i Grgu Smoljana. ${ }^{305}$ Tiskan je i proglas koji je potpisao Odbor Hrvoja Bratsko družtvo! ${ }^{! 30}$

304 "Hrvatsko narodno slavlje u Mostaru", u: Osvit, br. 65 i 66, Mostar, 20. 8. 1904.

305 "Odlikovani Hrvojevci i Hrvojevke", u: Osvit, br. 65 i 66, Mostar, 20. 8. 1904.

306 ABiH Sarajevo, Napretkova kulturno-historijska zbirka 747/IV, Bratsko družtvo: "U budjenju hrvatske svijesti u našoj miloj Bosni i Hercegovini najvažniju su ulogu igrala naša pjevačka družtva, koja su milozvukom hrvatske pjesme budilice trgnule narod iz stoljtnog sna, da ustane, da bude svoj na svome, da bude 
Osvit donosi iscrpne opise slavlja u dvobroju 67 i 68, od 27. kolovoza 1904. godine Hrvatsko narodno slavlje u Mostaru. Saznajemo da je kuma barjaka Andja ud. Fišić rođena Grabovac čiji je pokojni muž Nikola Fišić podupirao narodnu prosvjetu i naobrazbu. Ova velika hrvatska svečanost u Mostaru iskorištena je da se održi redovita skupština Saveza hrvatskih pjevačkih družtava koja gromkom pjesmom pronose glas Hrvatstvu i bude hrvatsku sviest, te služe narodnom jedinstvu. Skupština je održana 15. kolovoza 1904. u Franjevačkom samostanu u Mostaru, a otvorio ju je izaslanik Saveza gosp. Koser, koji je predložio dnevni red.

I u sljedećim brojevima Osvita nastavlja se s izvješćima drugoga dana svečanosti 14. kolovoza 1904. Posebno se zahvaljuje Dubrovčanima s kojima je došao i splitski načelnik vitez V. Milić. Goste je emotivnim govorom pozdravio i zahvalio im se na dolasku u Hercegovinu Ante Jukić. Predsjednik Gundulića prof. Krsto Krile je naglasio: "... da su Dubrovčani smatrali svojom dužnosti, da prisustvuju slavlju Hrvoja, koji toliko godina posluje na polju hrvatske prosvjete i sviesti, te želeći, da sve bude na slavu i diku Hrvatstva i hrvatske misli i mile domovine hrvatske!"307 Velika grupa Brotnjaka, oko 500, organizirano je došlo s fra Pavom Šimovićem na čelu. Seljaci iz Brotnja ispod trobojnice su pjevali hrvatske pjesme, a to je posebno iznenadilo viteza V. Milića. Nakon obreda u crkvi slavlje se nastavilo na pučkoj svečanosti na Balinovcu. ${ }^{308} \mathrm{U}$ zabavi su, uz Hrvoja, sudjelovali i članovi Davora iz Broda te Sokolaši iz Mostara i Sarajeva. Igralo se i pjevalo, kako gradsko, tako i seosko kolo, a ovu svečanost dobro je posjetila muslimanska inteligencija i građanstvo.

Osvit donosi i što o ovoj proslavi pišu hrvatski listovi pa prenosi iz uvaženog zadarskog Narodnog lista, koji na uvodnom mjestu opisuje za-

Hrvat! Pjevačka družtva u Herceg-Bosni bijahu pravi razsadnik hrvatske misli, bijahu ognjište hrvatskih ideja za dobrobit našega naroda, bijahu središte, gdje se sakupljahu svi, što hrvatski misle i osjećaju. A najstariji borac, prvi, koji je razvio zastavu borbe za sveto hrvatsko ime bijaše naš Hrvoje, koji je prije šesnaest godina na obali mutbe Neretve ispod krševitog Veleža zapjevao gromornu pjesmu:Hrvatska se Bosna diže,

Ljepša zora sviće njoj,

U kolo se, braćo, bliže,

Sad je Hrvat u svom svoj!

I gromorna pjesma Hrvojeva zaori od krša do krša, odjeknu i izpod starca Leutara, a Slavuljev glas iz trebinjskih dubrava odjeknu do kićenog Trebevića i eto Herceg-Bosna se probudi, diže, da u kolu svojih hrvatskih sestrica složna srdca pjeva velebnu pjesmu: Hrvatska Hrvatom."

307 "Hrvatsko narodno slavlje u Mostaru", u: Osvit, br. 69 i 70, Mostar, 3. 9. 1904.

308 "Sjajna pučka svečanost na Balinovcu", u: Osvit, br. 69 i 70, Mostar, 3. 9. 1904. 
bavu i instalaciju barjaka HGPD Hrvoja u Mostaru: "Moramo ovde još spomenuti, da je za dana svetčanosti skoro sav Mostar okićen bio hrvatskim trobojnicama i da ih je stiglo preko 500 brzojavnih pozdrava iz raznih hrvatskih zemalja, osobito iz Dalmacije." ${ }^{309}$ Vlast je bila rezervirana prema svečanosti, a Srbi su bili pasivni i s omalovažavanjem su se odnosili prema proslavi. Pučke novine Hrvatske stranke prava Hrvatska zastava piše: "Pjevala se hrvatska pjesma, padalo je lijepih besjeda i govora, ponosno se digao stieg hrvatski, da rekne na daleko i široko, da je Herceg-Bosna hrvatska bila i ostaje, ma se na nju digla četa dušmana. - Živio Hrvoje, živio Mostar, živila Herceg-Bosna." ${ }^{310}$ Svečanost je imala velikog odjeka u tisku, a to je još više podiglo ugled HGPD-a Hrvoje i dalo mu podstrek za daljnji rad. U broju 73, od 14. rujna 1904. Osvit, pod naslovom "Hrvatsko narodno slavlje u Mostaru", donosi sam tijek svečanosti instalacije Hrvojevog barjaka čija je kuma Andja ud. Fišić, a pjesnik i rodoljub Ante Jukić u svom govoru je naglasio: "Svakom narodu je zastava najveći i najmiliji amanet, njom se diči i ponosi, ona ga vodi k sreći i blagostanju, pod njom očekuje bolju i ljepšu budućnost, a hrvatski narod, koji ima zastavu častniju i sjajniju, nego mnogi drugi narodi, čija je zastava uviek nepobiedjena krčila put k slobodi i prosvjeti, tu zastavu mora hrvatski narod ne samo čuvati, nego se njom i pred čitavim svietom ponositi kao najsvećim svojim amanetom." ${ }^{311}$ Nakon mimohoda ulicama grada u svratištu Neretva priređen je svečani banket za 200 osoba. Ponovno su se redali govornici koji su klicali narodnom jedinstvu, hrvatskoj ideji i slavljeniku Hrvoji kojem su zaželjeli dug i plodonosan rad, a u ime kume zahvalio se pravnik i član Zmaja od Bosne gosp. Šefkija Gluhić koji je naglasio: "...da nazdravi mostarskim gradjanima, koji su velikim priegorom i težkim moralnim i materijalnim žrtvama podigli ovo družtvo na liepu visinu, te prvi utrli put osvješćujućoj hrvatskoj pjesmi, koja danas svojem prosvjetljujućeom i osvješćujućom moćju zagrijava i podiže cieli hrvatski narod ovih pokrajina."312 Poslan je i brzojav Mariji Kumičić u Zagreb u ime zahvalnosti oko izrade prekrasnog barjaka.

Naredni brojevi Osvita dali su veliki prostor i opis završetka svečanosti te govore koji su tom prilikom uzvanici i domaćini izmjenjivali kao i br-

309 "Novine o Hrvojevoj slavi barjaka", u: Osvit, br. 71 i 72, Mostar, 10. 9. 1904.

310 "Novine o Hrvojevoj slavi barjaka", u: Osvit, br. 71 i 72, Mostar, 10. 9. 1904.

311 "Hrvatsko narodno slavlje u Mostaru", u: Osvit, br. 73, 14. 9. 1904.

312 "Hrvatsko narodno slavlje u Mostaru, Banket", u: Osvit, br. 74, Mostar, 17. 9. 1904. 
zojavne pozdrave koji su stigli slavljeniku. ${ }^{313}$ Odbor HGPD-a Hrvoje koji je organizirao ovu proslavu instalacije društvenog barjaka sačinjavali su: predsjednik trgovac Petar N. Ančić, potpredsjednik učitelj Ante Jukić, tajnik činovnik Marko Glavina, zborovođa August Remec, blagajnik trgovac Nikola M. Smoljan, kazališni redatelj poduzetnik Marko Veble, knjižničar zlatar Friga Smoljan, barjaktar trgovac Jure ml. Smoljan, odbornici: trgovac Stjepan Smoljan, zlatar Marko Šiljeg i trgovac Ivan Slišković. Vidljive su promjene u društvenoj strukturi. Sada su dominantni trgovci koji čine polovicu članova, zlatari (obrtnici) 2 člana, po jedan član su učitelji, činovnik i poduzetnik. Zamjećujemo da nema redovnika koji su prije bili redovito članovi odbora, a obnašali su i dužnost predsjednika kao fra Augustin Zubac. Zborovođa je fra Ambro Miletić što je bio logičan nastavak rada društva kao nastavka crkvenog zbora. Početkom XX. stoljeća u gradu dolazi do jačanja građanske klase koja preuzima vodstvo HGPD Hrvoje u Mostaru. Naredni Odbor HGPD Hrvoje nastavit će ovaj trend uza stalno jačanje građanstva u upravi najstarijeg hrvatskog društva u Herceg-Bosni. Ovo je pokazatelj da je preporodna faza u samom gradu uspješno realizirana, a u narednom razdoblju trebalo je rad usmjeriti na prosvjetni i gospodarski napredak hrvatskog naroda i uključiti seljaka u proces hrvatske narodne integracije.

Izvanredna skupština HGPD-a Hrvoje održana je 23. studenog 1904. i izabrana je društvena uprava: predsjednik Petar N. Ančić, tajnik Mate Rimac, blagajnik Nikola M. Smoljan, arhivar Rafo Palandžić, knjižničar Jozo Soldo, odbornici: Ivan Boras, Ivan Slošković, Marko Šiljeg i Josip Maršalek. Revizori Jure Oreč i Petar Bašadur, a za barjaktara Stjepan Mihić. ${ }^{314}$ Društvo je ponovo oživjelo svoj rad i održavalo redovita sijela, a o drugom sijelu imamo izvješće u Osvitu kao i podatak da je dobro posjećeno u predbožićno vrijeme. ${ }^{315}$

Ova manifestacija pokazala je što HGPD Hrvoje znači za Hrvate, ne samo u Hercegovini, nego i u ostalim hrvatskim zemljama. Društvo je u drugom desetljeću svoga rada izraslo u jedno od vodećih, a njegov utjecaj na osnivanje hrvatskih društava u Hercegovini bio je velik. Već smo kod djelatnosti HGPD Slavulj, Trebižata i Hrvatske čitaonice u Konjicu naglasili povezanost i pomoć HGPD-a Hrvoje tim društvima prilikom njihovog osnivanja i početka rada. Pomoć se sastojala u dolasku članova na predsta-

313 "Brzojavni pozdravi", u: Osvit, br. 84, Mostar, 22. 10. 1904.: Veliki broj brzojava iz Daruvara, Drniša, Dubrovnika, Dubice, Ercegnovog, Glamoča, Gospića, Gruža, Imotskog, Jajca, Jasenovca i Jelse.

314 "Izvaredna skupština Hrvoje", u: Osvit, br. 95, Mostar, 29. 11. 1904.

315 "Hrvojevo sielo", u: Osvit, br. 99, Mostar, 14. 12. 1904. 
ve i njihovo sudjelovanje u istim te tehnička pomoć u kostimima i djelima koja se izvode. HGPD Hrvoje bio je pokretač i inicijator novih ideja koje su trebale rad društava podići na višu razinu, a kruna njegova rada je ova hrvatska manifestacija u Mostaru.

Početkom 1905. godine društvo nastavlja sa svojim zabavama s već ustaljenim programom, a odaziv građana je dobar. ${ }^{316}$ Koliko su društva bila značajna za proces hrvatske nacionalne integracije, pokazuje i činjenica da Osvit u svojim uvodnicima tu temu stalno naglašava kao i u tekstu Naša drǔ̌tva. ${ }^{317}$ Dopisnici često naglašavaju neke negativnosti u samom radu društava. Prilikom osnivanja društava, kada je bilo zabranjeno hrvatsko ime, rodoljubi su našli legalan način djelovanja kroz društva i čitaonice. Cilj je bio da uz njegovanje hrvatske pjesme i misli drže narod na okupu i rade na stvaranju uvjeta za osnutak narodne organizacije koja treba raditi na ujedinjenju Hrvata u Bosni i Hercegovini. Nažalost, mnoga društva ostala su samo na pjesmi i zabavi, a ovaj važniji zadatak nisu ispunili. Društva su trebala pod narodnim imenom okupiti sve društvene strukture unutar naroda, ali se zamjećuje da se unutar društava prave staleške razlike kao i razlike po položaju. Unutar društva moralo se raditi da vlada narodni duh bez obzira na stalež i položaj. Članovi društva moraju biti disciplinirani i poštivati društvena pravila koja su sami prihvatili. Ima pojava da su članovi željni slave što dovodi do zavisti kod drugih. Kad bi se ove slabosti iskorijenile, društva bi postala glavna središta socijalnog i gospodarskog napretka Hrvata u Bosni i Hercegovini. U Osvitu se javlja ideja oko osnivanja društvene zaklade kako bi pomogli i poboljšali rad hrvatskih društava u Bosni i Hercegovini. ${ }^{318}$

Osnova leži u pomoći članovima koji nemaju dostatna primanja te na taj način nisu u mogućnosti ispunjavati obveze prema društvenom pravilniku. Kako ovakvi članovi ne bi bili društvo u društvu, potrebno je iznaći način da im se pomogne na dobrobit njih, ali i društva. Hrvati u Bosni i Hercegovini nemaju društava za gospodarski napredak, pomaganje sirotinje, pomoć radnicima i radničkih zadruga za uzajamnu pomoć. Imali su samo pjevačka društva i čitaonice gdje se svi okupljaju bez obzira na stalež i položaj. Prvi korak bi bio osnivanje pripomoćne zaklade iz koje bi se financirali oni članovi koji su u teškoćama. Izvršni članovi su većinom radnici i obrtnici koji nakon svog napornog posla dolaze u društvo. Kada neki član oboli i nije u mogućnosti ispunjavati svoje obveze, onda bi se reagiralo iz zaklade. Iz zaklade bi se pomagali i oni obrtnici koji nema-

316 "Zabava Hrvoje", u: Osvit, br. 9, Mostar, 1. 2. 1905.

317 "Naša družtva", u: Osvit, br. 9, Mostar, 1. 2. 1905.

318 "Družtvene zaklade", u: Osvit, br. 11, Mostar, 8. 2. 1905. 
ju dovoljno kapitala da otvore svoj obrt, a oni bi kasnije vraćali dobiveni kapital u blagajnu zaklade. Prilikom odlaska u posjete drugim hrvatskim društvima mnogi članovi nisu bili u mogućnosti financirati put i boravak izvan Mostara, a gubili su i svoje nadnice pa u takve posjete odlaze samo bogatiji članovi. Protivnici ove ideje smatraju da je to osnivanje društva u društvu. Već unutar društva imamo glazbeni zbor, pjevački i kazališni pa nije razbijeno jedinstvo društva. Na ovaj način bi se unaprijedio rad društva, a posebice onih vrijednih izvršujućih članova koji bi mogli dati veći doprinos na kvaliteti rada u društvu.

HGPD Hrvoje nastavlja s glazbenim i kazališnim programom, a dolazi do polemike s Hrvatskim zemaljskim kazalištem u Zagrebu oko izbora predstava. Na repertoaru se našao i poneki strani komad što je bilo dovoljno za kritiku da treba igrati samo hrvatske komade. HGPD Hrvoje tražio je te komade, ali iz Zagreba nije bilo odgovora pa čak i da nikada nisu ni traženi, što nije bila istina. ${ }^{319}$ Koncert sa zabavom i plesom organiziran je 19. veljače 1905. u hrvatskom kazalištu doma Bratovštine. Tom prilikom izvedena je drama Zvonimir Kralj Hrvatski koju je režirao Marko Veble. ${ }^{320}$ Prvi predsjednik društva, koji je tu dužnost vršio čitavo desetljeće, Martin Čule umro je 3. srpnja 1905. u 48. godini. Podupirao je sve hrvatske akcije u Mostaru kao što je tiskara, Osvit i potporno društvo, a najviše je pomagao hrvatskog seljaka s kojim je suosjećao i znao prekoravati gospodu zbog položaja sela. Hrvoje je ispratio pokojnika na doličan način, a Đuro Džamonja na groblju Šoinovcu održao je žalobni govor i oprostio se od pokojnika u ime svih hrvatskih društava istaknuvši pokojnikove zasluge na tom polju. ${ }^{321}$

Na sprovodu fra Grge Martića članove Hrvoja su primili Hrvati iz Kreševa, a posebno se istaknuo načelnik Franjo Milošević. Prilikom putovanja u Kreševo Hrvatska čitaonica iz Konjica je dočekala i počastila članove Hrvoja koji su išli u Kreševo na sahranu hrvatskom Homeru. ${ }^{322}$ Kada bi se smanjio interes za probe i vježbe, članstvu bi upućivali poziv preko Osvita i tržili da redovito budu na probama kako bi društvo napredovalo. ${ }^{323}$ Vrijedni redatelj Marko Veble neumorno radi u Hrvoju i ostavlja veoma dobar dojam kod članova i posjetitelja predstava. Da bi mu se odužili, priredili su 11. veljače 1906. njemu u čast zabavu uza sudjelovanje vojničke glazbe.

319 "Opet Hrvojeve kazališne predstave", u: Osvit, br. 9, Mostar, 1. 2. 1905.

320 ABiH Sarajevo, Napretkova kulturno-historijska zbirka 1151/IV, Koncert sa zabavom i plesom 19. 2. 1905.

321 "Martin Čule", u: Osvit, br. 52, Mostar, 5. 7. 1905.

322 "Hrvatsko pjevačko družtvo Hrvoje", u: Osvit, br. 74, Mostar, 20. 9. 1905.

323 "Iz Hrvoja", u: Osvit, br. 74, Mostar, 20. 9. 1905. 
Potpredsjednik Đuro Džamonja je ocrtao rad Marka Veble i darovao mu zlatni prsten s natpisom Hrvoje 1906. u znak sjećanja na društvo. ${ }^{324}$ Koliko su pojedini članovi Hrvoja bili uspješni i cijenjeni i unutar drugih društava, govori nam podatak da je Muslimanska čitaonica iz Trebinja pozvala Jelku Soldo 10. ožujka 1906. da odigra ulogu Zlatije u drami Abdulah paša Safet bega Bešlagića. ${ }^{325}$ Dr. Matej Milas, jedan od predsjednika Hrvoja, umro je 10. travnja 1906. u Zagrebu. Bivši profesor Velike gimnazije u Mostaru pokopan je na Mirogoju. Radio je marljivo za Hrvoja i hrvatsku misao u Hercegovini, a vlast ga premješta u Tuzlu i Banju Luku. Za zasluge prilikom premještaja iz Mostara dobio je od Hrvoja zlatan prsten te ostao i dalje predsjednik HGPD-a Hrvoje. U Banjoj Luci uključio se u rad Nade i bio njezin predsjednik. ${ }^{326}$

U svibnju 1906. godine iznenada je umro učitelj Ante Jukić327 koji je dosta pisao pod pseudonimom Veljko Obradov. HPGD Hrvoje izgubilo je svog člana i održalo izvanrednu sjednicu u čast pokojnom Anti Jukiću. Na prostorijama društva izvješena je crna zastava, a hrvatska trobojnica na pola koplja. Koliko je pokojnik bio omiljen među hrvatskim društvima, govori i vijenac Hrvatskog pjevačkog društva Trebević iz Sarajeva koji su nosili članovi Hrvoja. Na grobu se od pokojnika oprostio pjesnik Stjepko Ilijić, a pročitana je i pjesma koju je poslao hrvatski pjesnik Josip Milaković Pobratimu Veljku (Anti Jukiću). ${ }^{328}$

U srpnju 1906. godine održana je Izvanredna glavna skupština HGPD-a Hrvoje kojoj je nazočno samo 20 članova, što je bilo za svaku osudu. Izabrani su novi odbornici: V. Jaričević i Marko Veble. ${ }^{329}$ Dobra suradnja Hrvoja i Sokola nastavlja se i oni su zajedničkim snagama priredili pučku svečanost na Balinovcu, krajem srpnja 1906. godine. ${ }^{330}$

324 "Hrvoje u počast svoga redatelja", u: Osvit, br. 12, Mostar, 10. 2. 1906.

325 "Jelka Soldo kao gošća u Trebinju", u: Osvit, br. 17, Mostar, 28. 2. 1906.

326 "Dr. Matej Milas", u: Osvit, br. 31, Mostar, 18. 4. 1906.

327 Ante Jukić rođen 21. 2. 1873. u Donjoj Tuzli, a umro 23. 5. 1906. u Mostaru. Učitelj u Trebinju, Žepču i Mostaru. Pisao pjesme pod pseudonimom Veljko Obradov. Surađivao u časopisima i uređivao Učiteljsku zoru i Učiteljski vjesnik. Izdavao kalendar Hrvoje. Vidi: Znameniti i zaslužni Hrvati te pomena vrijedna lica u hrvatskoj povijesti od 925.-1925., Emilij Laszowski (ur.), Zagreb, 1925., str. 122; "Ante Jukić", u: Osvit, br. 40, Mostar, 26. 5. 1906. Naslovna stranica uokvirena crnim florom, životni put i sahrana Ante Jukića.

328 "Ante Jukić", u: Osvit, br. 40, Mostar, 26. 5. 1906.

329 "Hrvojeva skupština", u: Osvit, br. 55, Mostar, 18. 7. 1906.

330 "Velika pučka zabava Hrvoje i Sokola", u: Osvit, br. 61, Mostar, 8. 8. 1906. 
Glavna skupština HGPD-a Hrvoja održana je 15. studenog 1906. uz potreban kvorum. Na prijedlog predsjednika Petra N. Ančića izvješće o radu u protekloj godini podnio je tajnik Stjepan Škobić. Napravljen je popis društvene imovine, a od aktivnosti treba spomenuti odlazak u Travnik na instalaciju hrvatske zastave Vlašića. Za češke sokolaše organizirana je zabava prilikom njihovog prolaska kroz Mostar. Tijekom protekle godine društvo je održalo 37 sjednica, 9 zabava, 3 koncerta i 3 sijela. Ova društvena aktivnost je dobro ocijenjena tako da je protekla godina bila jedna od uspješnijih u dugogodišnjem radu HGPD-a Hrvoje. Izabrano je novo rukovodstvo: za predsjednika Nikola M. Smoljan, tajnik je Stjepan Škrobić, blagajnik Petar Bašadur, arhivar Petar Šiljeg, knjižničar Pavao Lesko, barjaktar Stjepan Mihić, odbornici: Marko Veble, Ivan Boras, Marko Krezić i Ivan Kurtović, a za revizore Bruno Čović i Vilim Arapović. Odlučeno je da se na Dušni dan pjeva na grobovima zaslužnih članova društva: Frane Milićevića, Ivana Zovke i Ante Jukića. Zatraženo je da se dobije dozvola za uređenje doma s Bratovštinom sv. Ante. Donijeli su i odluku o osnutku čitaonice kao i da se više pažnje posveti prosvjeti i odgoju mladih. Prilikom sahrana članova Hrvoja nazočnost je obavezna, ali da se žalobne pjesme pjevaju na hrvatskom jeziku, a ne na latinskom te da se poduzmu aktivnosti oko tamburaškog zbora koji je zapušten. ${ }^{331}$

Prilikom velikoga kulturnog događaja 25. listopada 1906. u Mostaru je gostovala Marija Markiza Ružička-Strozzi, a 26. listopada na daskama hrvatskoga kazališta društva Hrvoje odigrana je Gospodja sa kamelija$m a$, u glavnoj ulozi nastupila je Markiza Marija Ružička Strozzi. Građani Mostara imali su priliku vidjeti veliku hrvatsku umjetnicu koja je svojom posjetom potakla interes publike za kazalištem. ${ }^{332}$ Sljedećega dana, 27. listopada, odigrana je Debora, a u pauzi nakon drugog čina tajnik Hrvoja gosp. Škobić predao je srebreni lovor vijenac ukrašen hrvatskom trobojnicom s natpisom: Prvakinji hrvatske Thalije - Hrvoje Mostar 27. X. 1906. Iznenađena glumica je zahvalila Hrvoju na odlikovanju. I sljedećeg dana, 28. listopada održana je šaljiva solo scena Kako da ga dočekam, a gosp. Džamonja, u ime mostarskih Hrvatica i Hrvata, zahvalio se na dolasku i umjetničkom užitku koji je priredila u Mostaru. Slavnoj umjetnici su uručili još jedan srebreni lovor vijenac s natpisom: Slavnoj našoj umjetniciHrvatice i Hrvati-Mostar 28. X. 1906. ${ }^{333}$ Svoj boravak u Mostaru iskoristila

331 "Glavna skupština Hrvoje", u: Osvit, br. 91, Mostar, 21. 11. 1906.

332 "Gostovanje hrvat. umjetnice Marije Markize Ružičke-Strozzi u Mostaru", u: Osvit, br. 85, Mostar, 31. 10. 1906.

333 "Gostovanje hrvat. umjetnice Marije Markize Ružičke-Strozzi u Mostaru", u: Osvit, br. 86, Mostar, 3. 11. 1906. 
je da posjeti vrelo Radobolje i Bune kojom je prilikom napravljeno više fotografija o njezinu boravku u Hercegovini. Mostarski hrvatski građani i Hrvoje izražavaju zahvalnost intendantu Hrvatskog zemaljskog kazališta u Zagrebu što su dopustili slavnoj umjetnici gostovati u Mostaru.

Na sprovodu istaknutog člana HGPD-a Hrvoje Ivana A. Smoljana, koji je umro 3. prosinca 1906. u 69. godini života, po prvi put Hrvoje je pjevao žalobnu pjesmu na hrvatskom jeziku Smiluj se meni gospodine. ${ }^{334} H G P D$ Hrvoje priredilo je svoju glavnu godišnju zabavu s plesom u čast desetogodišnjice otvorenja hrvatskog doma, a čitav prihod namijenjen je dogradnji hrvatskog doma. Na zabavi je bio glazbeni i dramski program u izvođenju amatera društva. ${ }^{335}$ Društvo daje dramske komade i priređuje zabave s plesom koji su dobro posjećeni, a roditelji traže da se za djecu organizira predstava Put oko zemlje za 80 dana od G. Vernea u prigodno vrijeme u 15 sati. ${ }^{336}$ Hrvoje neumorno radi na kulturnom uzdizanju naroda i izgradnji građanskih institucija u gradu pa tako otvara i čitaonicu u siječnju 1907. godine $^{337}$ koja treba "...da mladež mostarska sazna stanja i novosti iz svih hrvatskih krajeva, organiziraju se predavanja koja moraju biti posjećena, a naročito i od seljaka". ${ }^{338}$ Članovi Hrvoja inzistiraju upravo na dolasku seljaka kao najbrojnije strukture unutar društva. Širenje preporodne ideje na najšire slojeve pučanstva svakako je znak da se ulazi u završnu fazu nacionalne integracije. Kroz Hercegovinu prolaze putujuće družine koje su davale kazališne predstave s repertoarom iz nacionalne povijesti i na taj su način budile nacionalnu svijest. Postavljajući djela hrvatskih autora, pučanstvo se upoznaje s književnošću i preko kazališta, jer je veliki broj još nepismenih. Ove su predstave mogli pratiti svi, bez obzira na pismenost $\mathrm{i}$ čime su se bavili, tako da su one dobro posjećene. U sklopu Narodnog pjevačkog društva osnovana je i amaterska glumačka grupa i to je začetak kazališnog života u Mostaru i Hercegovini. Za premijeru su odabrali pučki igrokaz Graničari ${ }^{339}$ Josipa Frajdenrajba. Osobito su se istaknule gospođice Pavković, Zelenika i Ančić, a od gospode Šimun Smoljan. Izvode se djela Eugena Tomića, Mirka Bogovića i Ivana Kukuljevića Sakcinskog, ${ }^{340}$ koja su bila puna srčanosti i ljubavi prema rodu i jeziku. Predstave su izvođene

334 "Ivan A. Smoljan", u: Osvit, br. 95, Mostar, 5. 12. 1906.

335 "Hrvatsko glas.-pjev. društvo Hrvoje u Mostaru", u: Osvit, br. 13, Mostar, 31.1. 1907.

336 "Sa Hrvojeve zabave", u: Osvit, br. 18, Mostar, 13. 2. 1907.

337 "Hrvojeva čitaonica", u: Osvit, br. 5, Mostar, 12. 1. 1907.

338 Isto.

339 "Narodnog pjevačkog društva", u: Glas Hercegovca, br. 47, Mostar, 12. 12. 1888.

340 "Narodnog pjevačkog društva", u: Glas Hercegovca, br. 47, Mostar, 12. 12. 1888.; Josip Lešić, Grad opsjednut pozorištem, Sarajevo, 1969., str. 40. 
ljeti po baščama, a zimi nije bilo prikladna prostora pa se razmatra ideja o gradnji društvenog doma. Nakon 1890. godine postupno se uvode i komedije, a od hrvatskih pisaca zastupljeni su: Josip Ljubić, Mirko Bogović, Josip Eugen Tomić, Ilija Okrugić-Sremac, Stjepan Miletić, Janko Jurković i Iso Velikanović. ${ }^{341}$ Društvo je dobilo pozornicu i dvoranu $1897 .{ }^{342}$ i tom je prilikom organizirana velika zabava kojoj je nazočan velik broj mostarskih Hrvata. Dolaze kazališne trupe iz hrvatskih zemalja. Godine 1899. u Mostaru gostuje Dragutinovićevo Hrvatsko dramsko društvo ${ }^{343}$ koje daje predstavu u dvorani Hrvoja. Iduće godine dolazi iz Varaždina Hrvatsko dramsko društvo i mostarski amateri nastupaju s njima, a Marko Velba, ${ }^{344}$ zajedno sa suprugom ostaje u Mostaru kao redatelj, scenograf i glumac od 1901. do 1907.

Društvo ostaje tijekom 1907. godine bez svojih starih članova. ${ }^{345}$ Dugogodišnji redatelj Marko Veble oprostio se od HGPD-a Hrvoje i mostarskom publikom predstavom Škrtica. Uz njegov glumački talent predstava je uspješno odigrana, a da se druge uloge koje su igrali domaći amateri nisu primjećivale. Domaći amateri moraju se više potruditi oko učenja uloga, ali bilo je onih koji su odskakali i pokazali svoje umijeće na pozornici. Tu se ističu gospođice Anka Prusina, Anuška Juričićeva i Jelka Gadže, a od gospode Rafo Palandžić. ${ }^{346}$ Glavna godišnja skupština HGPD-a Hrvoje održat će se 9. studenog 1907. u prostorijama hrvatskog kazališta doma Bratovštine, a društvo je 1 . studenog organiziralo zabavu s plesom. ${ }^{347}$ Društvo je priredilo tradicionalnu zabavu 31. prosinca 1907. s glazbom, plesom i tombolom, a tajnik je održao predavanje Kako ćemo napredova-

341 J. LEŠIĆ, Grad opsjednut pozorištem..., str. 55.

342 Spomenica o 50-godišnjici..., str. 17.

343 J. LEšıć, Gad opsjednut pozorištem..., str. 72.

344 Isto, str. 89.

345 "Sprovod Ante M. Butigana", u: Osvit, br. 38, Mostar, 7. 5. 1907. Početkom svibnja 1907. godine umro je Ante M. Butigan bivši predsjednik HGPD Hrvoje te predsjednik Hrvatske dioničke tiskare i gradski vijećnik. Sprovod je predvodio fra Augustin Zubac, a HGPD Hrvoje je otpjevao pjesmu Pomiluj na hrvatskom jeziku. Od pokojnika se biranim riječima oprostio Marko Šešelj; "Javna zahvala", u: Osvit, br. 113, Mostar, 7. 11. 1907.; HGPD Hrvoje izgubio je svog utemeljitelja i prvog predsjednika fra Augustina Zubca koji je umro 5. studenog 1907. Na sprovodu je Hrvoje svoju zastavu zavio u crni veo, a pjevao je i tužaljke. Od pokojnika se opraštaju u ime građanstva i društva Đuro Džamonja i Stjepan Radulović. Pokojnik je samo prije pet mjeseci predvodio sprovod člana HGPD Hrvoje Ante M. Butigana.

346 "Oprosna večer gosp. Marka Veble-a", u: Osvit, br. 79, Mostar, 20. 8. 1907.

347 "Iz društva Hrvoje. Hrvojeva zabava", u: Osvit, br. 110, Mostar, 31. 10. 1907. 
ti. ${ }^{348}$ Povodom poklada HGPD-a Hrvoje priredio je ples pod maskama koji je dobro prihvaćen i donio društvu lijep prihod, a prava je šteta što glazba nije svirala, nego je puštana s gramofona. Ovo je jedna od prvih vijesti o novom tehničkom aparatu koji je svoju primjenu našao i u Mostaru. ${ }^{349}$ Samo malo opuštanja i neizvršavanja svojih obveza od strane vodećih članova dovodilo bi društvo pred velike probleme. Jedna teška situacija za HGPD Hrvoje dogodila se u proljeće 1908. godine. Zbog problema u radu društva postavila se dilema obustava ili raspuštanje društva. Izvanredna skupština HGPD Hrvoje održana je 14. travnja 1908. Bivši predsjednik Nikola M. Smoljan je otvorio je skupštinu i naveo razloge za ovakav dnevni red. O stanju i daljnjim koracima još su govorili Marko Krezić, Vilim Arapović i dr. Koehler te kako održati društvo na životu. Svi su jedinstveni oko opstojnosti Hrvoja, a navedeni su razlozi zašto je došlo do ovoga stanja. Nemar i nedisciplina izvršavajućih članova i slab interes podupirućih svakako je glavni uzrok ovog stanja. Predloženi su kandidati za novi društveni Odbor: predsjednik Nikola M. Smoljan, tajnik Vilim Arapović, blagajnik Ljubo Jurković, odbornici: Petar N. Ančić, Ivan Boras, Petar Soldo i Stjepan Mihić, arhivar Petar Šiljeg, knjižničar Nikola Kakarigji i revizori: Ivan Šešelj i Matej Banoža. Novoj upravi stavljen je zadatak da uredi stanje u društvu i da "Hrvoje, uzmogne svojoj zadaći odgovarati, kako se traži od najstarijeg pjevačkog društva u Herceg-Bosni." ${ }^{350}$ Odmah po Uskrsu HGPD Hrvoje priređuje zabavu koja je bila uspješna uz nastup pjevačkog zbora. ${ }^{351}$ Gostovanje koje je pobudilo veliki interes kod Hrvata u Mostaru je dolazak Hrvatskog narodnog kazališta iz Osijeka. Održano je 5 predstava, a izbor jednog djela kod građana, koji su bili nazočni na predstavi, bio je upitan. ${ }^{352}$ Prilikom proslave 30. godišnjice biskupovanja o. fra Paškala Buconjića održana je svečana zabava u Hrvoju, 19. travnja 1910. Na zabavi je nazočna svjetovna vlast, svećenici i građani Mostara koji su obožavali biskupa koji je u svom poslanju isticao katoličku vjeru i hrvatstvo kao temeljne postavke svog djelovanja. Biskupu se obratio Đuro Džamonja, koji je govorio o njegovom životu i radu, a nakon toga slijedio je pjevački dio iz opere Zrinjski i pučki igrokaz Barun Franjo Trenk. Ovo

348 "Hrvatsko-glasb.-pjev. društvo Hrvoje u Mostaru", u: Osvit, br. 135, Mostar, 31. 12. 1907.

349 "Karabuljna zabava u Hrvoji", u: Osvit, br. 26, Mostar, 5. 3. 1908.

350 "Izvanredna skupština hrvatskog glazb. pjev. društva Hrvoje", u: Osvit, br. 44, Mostar, 16. 4. 1908.

351 "Hrvojeva zabava", u: Osvit, br. 46, Mostar, 21. 4. 1908.

352 "Peta predstava Hrvatskog nar. kazališta iz Osijeka u Hrvoju", u: Osvit, br. 64, Mostar, 4. 6. 1908. Dato je djelo Smrt majke Jugovićke što je smatrano neprimjerenim za Mostar i hrvatsko građanstvo. 
je svakako bila jedna od najboljih zabava u Hrvojevoj dvorani kojom je na dostojan način obilježen biskupov jubilej. ${ }^{353}$ HGPD Hrvoje organiziralo je koncert s plesom 8. rujna 1910. i dramskim programom, a nakon toga uslijedio je ples do kasno u noć. ${ }^{354}$

HGPD Hrvoje obilježilo je 80. godišnjicu rođenja slavnog skladatelja Ivana pl. Zajca koncertom u društvenom domu Hrvoja 28. siječnja 1911. ${ }^{355}$

U Kršćanskoj obitelji izišao je tekst povodom proslave Narodnog blagdana sv. Ćirila i Metoda, Hrvatski narode! "Po koji put pokucaše pa i sad pokucavaju hrvatska nam braća iz šire naše hrvatske domovine, na bratska srca naša, tržeći od nas pomoć, u svrhu, da se najljepši naši krajevi ne otudje od majke nam hrvatske domovine. Na čelu te naše braće kao vazda stoji družba Ćirila i Metoda, koja nastoji da ovog puta i mi dan tih slavenskih apoštola proslavimo diljem cijele naše domovine kao prigodni blagdan, i da tog dana svaki nas pojedini doprinese svoj obol za podizanje hrvatskih škola u ugroženim krajevima naše domovine kao najbolji ustuk tugjoj najezdi. Sa raznih se tamo krajeva podigao neprijatelj, da nam uništi materinski jezik, da nam otme narodnost, da nam napokon uništi milu hrvatsku domovinu." ${ }^{356}$ Akcija za podizanje škola u ugroženim hrvatskim krajevima: Međimurju, Slavoniji, Rijeci i Istri. ${ }^{357}$ Hrvati u Mostaru i Hercegovini pokazali su senzibilitet za hrvatsku stvar i budno pratili što se događa u drugim hrvatskim zemljama.

Tijekom 1911. godine Hrvatsko pjevačko društvo Hrvoje priredilo je veliku godišnju zabavu 1. studenog 1911. u svojim prostorijama s dramom Knez Nikola Zrinjski. ${ }^{358}$

353 "Svečana zabava u Hrvoju", u: Hrvatska obrana, br. 15, Mostar, 23. 4. 1910.

354 "Zabava hrv. pjev. glazb. Društva Hrvoja", u: Hrvatska obrana, br. 35, Mostar, 17. 9. 1910.

355 ABiH Sarajevo, Napretkova kulturno-historijska zbirka 1385/IV, Prigodom 80. godišnjice rogjenja Ivana pl. Zajca.

356 "Za proslavu Narodnog blagdana sv. Ćirila i Metoda", u: Kršćanska obitelj, Mostar, br. 7. i 8. od 1. srpnja 1911., str. 154. Odbor u Mostaru sastavljen iz svih hrvatskih društava u Mostaru: Okružnog odbora Hrvatske narodne zajednice, Hrvoja, Hrvatskog Sokola, Napretka, Hrvatske radničke zadrzge i Bratovštine sv. Ante. Proslava Narodnog blagdana je 5. srpnja, a poziv je upućen 30. lipnja 1911.

357 "Za proslavu Narodnog blagdana sv. Ćirila i Metoda", u: Kršćanska obitelj, Mostar, br. 7. i 8. od 1. srpnja 1911., str. 154. Odbor u Mostaru sastavljen iz svih hrvatskih društava u Mostaru: Okružnog odbora Hrvatske narodne zajednice, Hrvoja, Hrvatskog Sokola, Napretka, Hrvatske radničke zadrzge i Bratovštine sv. Ante. Proslava Narodnog blagdana je 5. srpnja, a poziv je upućen 30. lipnja 1911.

358 ABiH Sarajevo, Napretkova kulturno-historijska zbirka 1152/IV, Velika godišnja zabava 1. 11. 1911. 
Za poklade 18. veljače 1912. priređuje pokladnu zabavu. ${ }^{359}$ Oko 50 članova HGPD-a Hrvoje i fanfarama Sokola 24. ožujka 1913. dolaze u Trebinje kako bi pomogli u realizaciji izgradnje Društvenog doma Slavulja. Drugi dan po Uskrsu održan je zajednički koncert s plesom. Ideja oko Društvenog doma nije nikada realizirana i nije dalje otišla od kupovine zemlje u Begovini koja je kasnije prodana časnim sestrama Franjevačke provincije iz Mostara. I u ovo predratno vrijeme suradnja dva vodeća hrvatska društva je bila dobra i stalna. Oni se još jednom te godine susreću u Sarajevu prigodom proslave otvorenja zgrade Zakladnog doma Hrvatskog kulturnog društva Napredak, 27. i 28. rujna 1913. ${ }^{360}$ Tijekom rata društvo je izgubilo dosta članova, a neki su i raseljeni tako da je aktivnost društva zamrla. Rat je gotovo obustavio djelovanje društva, a društvene prostorije su zapuštene i propalo je dosta rekvizita i kostima. Najveći gubitak su bili vrijedni članovi koji su otišli u rat ili se raselili, a omladina nije mogla pristupiti društvu. Nakon rata mostarski Hrvati poduzimaju aktivnosti oko aktiviranja HGPD Hrvoje. Aktivira se pjevački zbor, a Hrvatska glazba postaje samostalna. Prvi javni nastup bio je 30. travnja 1919. u spomen na tragičnu smrt hrvatskih mučenika Petra Zrinjskog i Franje Krste Frankopana. Nakon završetka rata i stvaranja Kraljevstva SHS Hrvatsko glazbeno pjevačko društvo Hrvoje priredilo je 8. prosinca 1919. Veliku godišnju zabavu. ${ }^{361}$

Kako je bilo problema s glazbenim zborom u Hrvoju i on nije već duže vrijeme bio u funkciji, prišlo se organiziranju Hrvatske glazbe u Mostaru, u travnju 1919. godine. Hrvatsko glazbeno društvo u Mostaru imalo je zadatak njegovanja instrumentalne glazbe i unaprjeđivanja društvenog života. Za predsjednika izabran je veleposjednik Martin Suton, zamjenik je urednik novina Kramer Gjuro, tajnik kancelista Franjo Pezelj, blagajnik zubotehničar Nikola Fertilio, arhivar priv. Stud. Ljubomir Sočo i veletrgovac Stojan Miličević te odbornici: Adolf Bjelobrk, Leo Šešelj i Rudolf Kumpara. ${ }^{362}$

HGPD Hrvoje je od svog osnutka 1888. godine, kao najstarije hrvatsko društvo, svojim dugogodišnjim radom, entuzijazmom svojih članova te

359 ABiH Sarajevo, Napretkova kulturno-historijska zbirka 1153/IV, Velika pokladna zabava 18. 2. 1912.

360 Mirela MiličEvić-ŠEčıć, "Civilni puhački orkestri u Hercegovini u razdoblju austrougarske uprave", u: Hercegovina, 24, Mostar, 2010., str. 223-233.

361 ABiH Sarajevo, Napretkova kulturno-historijska zbirka 1159/IV, Velika godišnja zabava 8. 12. 1919.

362 ABiH Sarajevo, Napretkova kulturno- historijska zbirka 1733/IV, Pravila Hrvatske glazbe u Mostaru travanj 1919. 
umjetničkim postignućima bilo i ostalo uzor ostalim hrvatskim društvima u Herceg-Bosni. Neumorno radeći na podizanju kulture, ne samo u Hercegovini, nego i u Bosni, društvo je stalno inicijator mnogih akcija koje su podržavala i ostala hrvatska društva. Nesebično pomažući drugima, postalo je omiljeno društvo te je bilo putokaz i smjernica za ostala hrvatska društva kojim putem trebaju ići.

\section{HRVATSKE UDRUGE U MOSTARU}

Kako za vrijeme osmanske vlasti, a jedan period ni u Austro-Ugarskoj Monarhiji, nije se moglo politički javno djelovati pa se zbog toga prišlo osnutku različitih kulturnih udruga. Ove udruge davale su poticaj razvoju hrvatske narodne ideje i bile su nezaobilazan čimbenik u procesu hrvatske nacionalne integracije. U početku svoga rada udruge su okupljale redovnike, učitelje i građane (osobito trgovce). Kasnije se u udruge uključuje i seljački sloj hrvatskoga pučanstva koji je, dakako, najbrojniji, a to je bio i znak da je proces hrvatske nacionalne integracije ušao u svoju završnu fazu. Franjevci su nakon svoga dolaska u Hercegovinu veliku pozornost posvetili katoličkom pučanstvu i nastojali mu biti od pomoći i na gospodarskom, prosvjetnom i kulturnom polju. Za pomoć sirotinji franjevci su u Mostaru osnovali 1872. godine Pobožnu zadrugu svetog Ante Padovanskoga iz koje će niknuti društvo Hrvoje i druga hrvatska društva u Herceg-Bosni. ${ }^{363}$ Za promicanje gospodarskih interesa Hrvata u Mostaru i Hercegovini franjevci osnivaju 1856. godine narodnu blagajnicu $^{364}$ kojoj je svrha štednja i pomoć. Osmanska vlast nametnula je uskoro zajednički sanduk 1870. godine. Franjevci uza samostan na Sirokom Brijegu podižu 1863. godine "...sedam dućanah upravljenih od o. Andjela Kraljevića, porad uzdignutja, i uputjenja puka, i u kojima od svake versti sprave moće se najti kao i u Mostaru..."365

Biskup fra Anđeo Kraljević je, po uzoru na slične zaklade na Zapadu, osnovao 1872. godine Mons pietatis u Mostaru. Ova zaklada trebala je pomoći hrvatskom seljaku prilikom otkupa od kmetstva. Zahvaljujući ovoj zakladi do 1878. godine preko 150 siromašnih katolika kupi-

363 Marko ŠešelJ, "Bratimstvo sv. Antuna Padovanskog", u: Hrvatska domovina, br. 134, Zagreb, 14. 6. 1897., str. 2-5.

364 Isto.

365 Sveučilišna knjižnica u Zagrebu, Nekoliko Punatah iliti Kratko opisanje; od Poslanjstva Male bratje u Hercegovini I u komu se ukazuje, koliko je nasiljev ista podniela od turakah. S nadodatjem mlogihdrugih stvarih potriebnih znanju. Skupljeno Po nastojanju jednog svetčanika Hercegovca, R. 3699., str. 24. 
lo je kuće i zemlju. ${ }^{366}$ Godine 1875. tajno se osniva u Mostaru društvo Kosača ${ }^{367}$ jer osmanlijske vlasti nisu dale odobrenje za njegovu legalnu djelatnost. Dolaskom Austro-Ugarske Monarhije osniva se Narodno pjevačko društvo 1888. godine koje se kasnije naziva Hrvatsko glazbeno i pjevačko društvo Hrvoje. ${ }^{368}$ Zatim se osniva Sokol u Mostaru 1896. godine, a 1902. godine promijenjeno je ime u Koturaško gombalačko društvo Sokol u Mostaru. ${ }^{369}$ Za pomoć siromašnim učenicima i studentima osniva se Hrvatsko potporno društvo za potrebe đaka srednjih i visokih škola iz Bosne i Hercegovine sa sjedištem u Mostaru. Društvo je odobreno 5. srpnja 1902. Odlukom Visoke Zemaljske vlade u Sarajevu br. 2544-IB. ${ }^{370}$ Konstituirajuća skupština održana je 14. rujna 1902., a članovi i utemeljitelji su Ivan Vitez Trnski iz Zagreba, dr. Frano Iveković iz Zagreba (kanonik) i dr. Vatroslav Reiner, advokat iz Karlovca. ${ }^{371}$ Osnivači Društva su fra Radoslav Glavaš, prof. L. Januicki i Martin Čule. ${ }^{372}$ Kasnije se ovo Društvo spaja s Napretkom, ${ }^{373}$ a u tome se vidi težnja mladoga hrvatskog građanstva, svjetovne inteligencije, obrtnika i trgovaca da preuzmu vodeću ulogu (od franjevaca) u preporodu. Ova promjena vodstva značila je i prelazak središta borbe za hrvatsku stvar iz Mostara u Sarajevo, gdje je početkom XX. stoljeća većina hrvatske inteligencije i građanstva. Osnivanjem čitaonica i škola u Mostaru podignuta je kulturna razina hrvatskih pučana u gradu, a cilj tih institucija bilo je širenje pismenosti kao i nacionalno osvješćivanje hrvatskoga pučanstva. U Mostaru se osniva ukupno 39 različitih udruga:

Čitaonička i društva za druževnost u Mostaru, 19

366 Leo Petrović, "Fra A. Kraljević, Apostolski vikar u Hercegovini 1807.-1879.", u: Napredak, 29, Sarajevo, 1939., str. 113.

367 Spomenica o 50-godišnjici..., str. 9.

368 ABiH Sarajevo, Napretkova kulturno-historijska zbirka, 1139/IV, Pravila za narodno pjevačko družtvo u Mostaru usvojena 10. kolovoza 1888. godine. Zemaljska vlada 10. 11. 1888. odobrila br. 1373/res na osnovi otpisa zajedničkoga Ministarstva od 3. 11. 1888., br. 783. B. H., Za poglavicu Zemaljske vlade administrativni upravitelj Sauerwald.

369 Osvit, br. 50-51, Mostar, 28. 6. 1902., str. 4.

370 Osvit, br. 69, Mostar, 3. 9. 1902., str. 5.

371 Osvit, br. 88, Mostar, 8. 11. 1902., str. 4.

372 L. ĐAкоvić, Političke organizacije bosanskohercegovačkih katolika Hrvata, str. 248.

373 Napretkova podružnica u Mostaru osnovana je 20. siječnja 1907. Vidi: L. ĐAKović, Političke organizacije bosanskohercegovačkih katolika Hrvata, str. 248. 
Pjevačka i muzička društva u Mostaru, 7

Dobrotvorna društva u Mostaru, 5

Vatrogasna, 2

Gimnastička i turistička društva, 2

Koturaško društvo, 1

Udruženje za zaštitu staleških interesa, 1

Zanatlijska društva, 1

Vjersko društvo, 1

Ukupno: $39^{374}$

Hrvatski radnici se u Mostaru kao i Ljubuškom 1906. godine bore za svoj položaj unutar društva organizirajući štrajkove. ${ }^{375}$ Ovi novi momenti su upozorili poslodavce i vlast da se nešto mora promijeniti u položaju

374 Izvještaj o upravi u BiH 1906. - Izdalo C. i Kr. Zajedničko ministarstvo financija, Zagreb, 1906., str. 609.

375 Arhiv Hercegovine Mostar, MIH-30. Opširno izvješće štrajka u Ljubuškom od 26. 5. 1906.; "Herceg-Bosna", u: Hrvatsko pravo, br. 3161, Zagreb, 30. 5. 1906.; "Štrajk u Ljubuškom", u: Osvit, br. 38 i 39, Mostar, 19. 5. i 23. 5. 1906. S razvojem prvih pogona u Hercegovini nastaje i radnička klasa koja je na tržištu rada potpuno nezaštićena jer još nisu bili stvoreni uvjeti koji bi joj osigurali prava. Kako su poslodavci bili bezobzirni prema radnicima, rezultiralo je i prvim štrajkovima u Mostaru i Ljubuškom. Događaji u Sarajevu, demonstracije i štrajk sarajevskih radnika, nisu ostali nezapaženi i u Mostaru. Osnovni zahtjev je bio da se uvedu radnička prava i poboljša položaj radnika. Radnici su započeli pripreme za radničku skupštinu kako bi poboljšali svoj položaj i zaštitili svoja prava. Izabran je odbor od tri člana: krojač Pavao Lesko, cipelari Danilo i Salko Muratović koji su dobili dozvolu za sazivanje radničke skupštine koja je održana 17. svibnja 1906. Na prijedlog Pavla Leske za predsjednika skupštine izabran je tipografski radnik Milan Zubac, a za perovođu (pisara, zapisničara) izabran je Gabrijel Bokšić. Skupštini se obraća i Đuro Džamonja kao predstavnik javnog tiska i pozdravlja ovaj prvi korak našeg radništva. Poziva ih da na miran i dostojanstven način iskažu solidarnost sa sarajevskim radnicima. Predloženo je da se od svakog zanata izaberu po dvojica predstavnika u odbor za pregovore s poslodavcima. Zahtijevano je: 1. povišica plaće svim radnicima; 2 . ukinuće pogodbe rada na godinu; 3 . ukinuće argatije (cestarine, kuluka); 4. uspostava povjerenstva koja treba pregledati stanove radnika i radionice. $U$ tom povjerenstvu treba biti većina radnika; 5 . ukinuće kućeberskih dozvola i da se dopusti stvaranje radničke organizacije, sloboda tiska, zbora i dogovora. Ovi prijedlozi su jednoglasno usvojeni. 
i pravima radnika kao i da im se dopusti sloboda organiziranja radničkih udruga, zbora i govora. Kako bi mogli bolje zaštiti svoje interese i popraviti svoj položaj, nacionalno svjesni hrvatski radnici u Mostaru osnivaju

Nakon ovoga radnici kreću u povorci kroz grad, od svratišta Bosna do velike Tepe. Najavljeno je da će sutra nakon povratka s vježbe radničko izaslanstvo primiti poglavar zemlje.

Odbor se sastajao svakog dana u svratištu Bosna dok se nisu gotovo svi radnici nagodili sa svojim poslodavcima. Sjednicama su bili nazočni: Đuro Džamonja, Aleksa Šantić, Svetozar Ćorović i Šerif Arnautović, koji su nastojali dati svoj doprinos u rješavanju spornih točaka.

Petkom je započeo štrajk u tvornici duhana. Radnice i radnici krenuli su u povorci kroz grad gdje su im građani iskazali solidarnost. Izabrani su predstavnici za Odbor i oni su iznijeli svoje zahtjeve upućene od strane radnica upravi tvornice. Đuro Džamonja je pozvan kod okružnog predstojnika Pitnera i optužen je kao začetnik i vođa radničkoga pokreta, a na vijest da je uhićen počela je vika i prosvjed. Traženo je da se urednik Osvita pusti na slobodu. Džamonja je izišao pred radnike i prošetao se gradom kako bi umirio stanje među radnicima, a njemu se pridružio i Aleksa Šantić.

Nakon toga je Đuro Džamonja obrazložio zemaljskom poglavaru zahtjeve radnika, a on je neke podržao i dao obećanje da će ubuduće raditi na poboljšanju položaja radnika. Kada je odgovor priopćen radnicima, oni ponovo održavaju skupštinu. Radnice su pregovarale u tvornici duhana sa svojim poslodavcem koji se vratio s izleta iz Dubrovnika. Iznijele su svoje pritužbe kako s njima postupaju nadglednici i niži činovnici, kao i zahtjeve za povišicom na koju je pristao ravnatelj. Dogovoreno je da će ostale pritužbe ispitati. To nije zadovoljilo radnice koje traže ispunjenje svih zahtjeva. Došlo je do pobune trgovaca i gostioničara koji su tražili da trgovci na veliko ne prodaju robu u maloprodaji i da im na taj način ne prave konkurenciju. Kako bi smirili situaciju, gradsko poglavarstvo je održalo izvanrednu sjednicu.

Osim Mostara u Hercegovini je po broju radnika značajan i Ljubuški, zbog većeg broja zaposlenih u otkupnoj stanici za duhan. Štrajk se širi i na Ljubuški 16. svibnja 1906. gdje radnici traže povećanje dnevnice. Oko 500 radnica i radnika otkupne duhanske stanice je 17. svibnja stupilo u štrajk. List Hrvatsko pravo u svome broju 3161 od 30. svibnja 1906. objavio je članak pod naslovom Herceg-Bosna. U tom članku dano je opširno izvješće o generalnom štrajku u Ljubuškom 1906. godine.

"Velik broj naroda, njih oko 4000, okupilo se na skupštini u blizini Franjevačkoga samostana na Humcu, zbog toga što im oružnici nisu dopuštali ulazak grad. Zahvaljujući fra Boži Ostojiću koji je smirio narod i otvorio skupštinu te ih pozvao da iznesu svoje zahtjeve, uspostavljen je mir. Tada su pravnik Fahrudin M. Tančica i fra Anto Majić zatražili da izaberu svoje predstavnike koji će iznijeti zahtjeve te ih napisati i narodu pročitati. Građanstvo, radništvo i seljaštvo kotara Ljubuškog predložilo je nadležnoj vlasti rezoluciju:

1. Traže slobodu tiska, zbora i dogovora jer je to uvjet narodnog napretka.

2. Da se ukine kuluk i da se odredi prirez na porez i od toga da se putovi uzdržavaju. 
3. Traže slobodno i jednako pravo glasa pri gradskim izborima, kako bi narod izabrao predstavnike koji će zagovarati pravo građanstva.

4. Općinskim službenicima bolja plaća i odgovarajuća mirovina i da vlada uzdržava mjesnu narodnu školu kada općina nije u stanju.

5. Visoka vlada da održava kanale i nasipe.

6. Državni erar da se dopusti narodu kao ispaša.

7. Da narod izabere procjenitelje duhana, a da ih plaćaju od prireza na duhan.

8. Otkup duhana po cijeni koja je bila za prve tri godine.

Zahtjevi se odnose na: duhan, izbora glavara, poljara, održavanja kanala, domaćeg vina, stočarstva kao i plaće liječnika i taksa za svako selo. Ovo su bili životni problemi s kojima se narod susreće i uviđa da se treba nešto učiniti kako bi poboljšali svoj položaj. Veliki broj radi u otkupnoj stanici za duhan u Ljubuškom. Sam otkup i sortiranje duhana zahtijevao je dosta radnika. Jedan dio je bio zaposlen stalno, a drugi dio je sezonski, kada je trebalo dodatne radne snage za vrijeme vage u jesen.

Ovi navedeni zahtjevi obuhvatili su sve društvene strukture pučanstva kotara Ljubuški i njihov cilj je bio poboljšanje položaja naroda. Ovo je narodu pročitano što je i jednoglasno usvojeno. Kotar Ljubuški je zahvaljujući rijeci Trebižatu, koja sustavom kanala natapa polje, veliki poljoprivredni proizvođač. Seljak je veliki poljoprivredni proizvođač i zahvaljujući toj činjenici može živjeti od poljoprivrede. Duhan, kao relativno nova kultura, bila je državni monopol. Svake godine država donosi otkupne cijene za pojedine klase duhana u listu koji se otkupljuje na vagi u jesen od seljaka. Kvalitetu duhana određuju procjenitelji koji su jedan od zahtjeva štrajkaša, a formiranje otkupne cijene je od strane duhanske režije. Ovaj problem je stalan, a kako bi narod doskočio tomu, okreće se crnom tržištu i križanju duhana za ilegalnu prodaju. Jedan od razloga zašto se duhan proizvodi u Hercegovini jest svakako i činjenica da proces proizvodnje zahtijeva dosta rada, a mnogobrojne seoske obitelji na taj način osiguravaju svoju egzistenciju. Djeca su sudjelovala u branju i nizanju duhana kao i njegovom sortiranju u bale kako bi bio spreman za jesenju vagu i otkup. Uz duhan je značajno i vinogradarstvo. U podrumima se odvija proizvodnja domaćega vina i rakije koje jednim dijelom koriste za svoje potrebe, a drugi im služi za prodaju ili se trampi za neke druge poljoprivredne kulture, najčešće krumpir.

Radnici duhanskoga otkupnog ureda u Ljubuškom su pročitali svoje zahtjeve:

1. Povećanje plaće radnicima i radnicama od 30 do $40 \%$.

2. Radni dan da traje osam sati, sada je deset.

3. Ukidanje novčanih kazni.

4. Da se povrate radnici koji su radili preko 10 godina a potjerani su.

5. Da se upošljavaju isključivo radnici iz kotara Ljubuškog.

6. Da se radnicima koji su radili preko 20 godina isplati pola plaće kao potpora, a nesposobni su za daljnji rad.

7. Da žene ne rade teške poslove (nošenje bala).

8. Da postupanje s radnicima bude uljudno i da se poštuju njihovi vjerski osjećaji.

9. Da odstrane radnike iz drugih kotara.

10. Da nema nikakvih postupaka prema radnicima zbog učešća u štrajku. 
Hrvatsku radničku zadrugu 1907. godine. ${ }^{376}$ Sve ove udruge imale su veliku ulogu u buđenju i okupljanju različitih društvenih struktura, Hrvata u Mostaru i širenju procesa hrvatske nacionalne integracije. Uključivanje u preporodna gibanja različitih profesionalnih grupa i različitih društvenih struktura unutar hrvatskoga pučanstva značilo je i širenje procesa nacionalne integracije, odnosno završno razdoblje u tijeku procesa hrvatske nacionalne integracije u Mostaru.

Nakon čitanja i usvajanja ovih zahtjeva oni su upućeni nadležnoj vlasti, a ona direktoru u Ljubuškom. Udovoljeno je svim zahtjevima, a plaća je povišena za $25 \%$. Zahtjev za $40 \%$ povećanja proslijedit će se ministarstvu, a nakon mjesec dana javiti rezultat. Štrajk je završio 21. svibnja 1906., a uhićeno je preko 25 radnika, koji su završili u zatvoru. Vojska je za vrijeme štrajka bila raspoređena posvuda po Ljubuškom i trajalo je opsadno stanje. Kada se situacija smirila, nije bilo potrebe za vojskom, ostaju samo žandari koji su bili i prije: skoro čitava kumpanija žendara sve ko jablanova."

Iz radničkih zahtjeva jasno se vidi da oni zahtijevaju bolji materijalni položaj, bolje radne uvjete, osmosatni radni dan, bolje uvjete za žene, socijalne uvjete za starije radnike kao i sam odnos nadređenih prema radnicima.

Ovaj štrajk u Ljubuškom je pokazao da su svi slojevi nezadovoljni stanjem u društvu i da traže poboljšanje uvjeta rada i života. Traži se od viših institucija vlasti da pomogne ovom kraju koji eksploatira kroz malu cijenu otkupa duhana koji je državni monopol. Nakon što su i radnici iskazali svoje nezadovoljstvo, trebalo je prići stvaranju prvih radničkih organizacija kroz koje će lakše ostvarivati svoje ciljeve i štititi svoj stalež.

Ovi novi momenti su upozorili poslodavce i vlast da se nešto mora promijeniti u položaju i pravima radnika kao i da im se dopusti sloboda organiziranja radničkih udruga, zbora i govora. Vidi opširnije: "Veliki radnički štrajk u Mostaru", u: Osvit, br. 38, Mostar, 19. 5. 1906.: Čitav jedan stupac izbacila je cenzura. "Veliki radnički štrajk u Mostaru", u: Osvit, br. 39, Mostar, 23. 5. 1906. Cenzura je izbacila pojedine dijelove teksta. "Štrajk u Ljubuškom", u: Osvit, br. 39, Mostar, 23. 5. 1906.; Arhiv Hercegovine Mostar, MiH-30. Opširno izvješće štrajka u Ljubuškom od 26. 5. 1906.; "Herceg-Bosna", u: Hrvatsko pravo, br. 3161, Zagreb, 30. 5. 1906.

376 Tinomir Zovko, "Radništvo u Hercegovini i njegovo uključivanje u proces hrvatske nacionalne integracije", u: Hum, br. 10, Mostar, 2013., str. 199-223. HRZ je organizacija hrvatskih obrtnika, zanatlija i radnika djelovala, s kraćim prekidom, do 1920. godine. Cilj je bio međusobno pomaganje i poboljšanje položaja radnika i borba za radnička prava, njegovanje vjere, suzbijanje bezvjerstva te borba za nacionalne interese. 


\section{Zaključak}

Mostar je tijekom XIX. stoljeća doživio velike promjene u nacionalnoj strukturi koja se mijenja nakon višestoljetne stagnacije, u korist katolika. Grad se proširuje i gradi se po uzoru na srednjoeuropske gradove dobivajući moderne urbanističke obrise. Kasaba se pretvara u grad koji dobiva europski izgled i institucije koje se izgrađuju po novome europskom modelu. Grad se širi, grade se prometnice koje ga povezuju s ostalim središtima u Hercegovini, Bosni i Dalmaciji. Ono što je više od četiri stoljeća Osmanlijsko Carstvo zabranjivalo i na različite načine ograničavalo, u četiri desetljeća nazočnosti katoličke Monarhije drastično se promijenilo. Taj proces započeo je još u osmanlijskom periodu osnivanjem katoličkih institucija početkom 70-ih godina XIX. stoljeća kada grad postaje i važno kulturno središte Herceg-Bosne. Tiskara i izdavačka djelatnost potaknut će razvoj školstva ali i utemeljiti novinsku djelatnost izdavanjem prvih novina kod Hrvata u Hercegovini. Osnivanjem Bratovštine sv. Antuna Padovanskog, tiskare, čitaonica i društva Hrvoje započeo je proces uključivanja različitih društvenih struktura $\mathrm{u}$ proces integracije hrvatske nacije. Brojne hrvatske institucije u gradu dat će poticaj i drugim krajevima Hercegovine na osnivanju hrvatskih društava i biti im uzor u njihovu djelovanju. Nakon 1878. godine provodi se ubrzana urbanizacija i od osmanlijske kasabe postaje tijekom naredna četiri desetljeća moderan europski grad s planiranim prometnicama, trgovima te profanim i sakralnim građevinama. Prometnom infrastrukturom, izgradnjom željezničke pruge, Mostar se povezuje sa Savom i Jadranskim morem. Gradnjom cestovne mreže prema istoku, jugu i zapadu povezuju se ruralni prostori Hercegovine sa svojim središtem. Mostar postaje i gospodarsko središte Hercegovine. Djelovanje različitih hrvatskih institucija i udruženja u gradu dat je veliki zamah procesu hrvatske nacionalne integracije, a Hrvati iz Mostara su primjer za sve ostale u Herceg-Bosni kako treba raditi za nacionalni interes. $\mathrm{Hr}$ vatsko glazbeno pjevačko društvo Hrvoje svojim radom bilo je primjer i poticaj ostalim hrvatskim društvima u Herceg-Bosni kako treba raditi za narodnu stvar. Iz djelovanja Hrvoja izrast će ozbiljna amaterska kazališna sekcija koja će razvijati kod građanstva ljubav prema ovoj umjetnosti. Veliki broj različitih hrvatskih udruga djelovalo je u Mostaru krajem XIX. i početkom XX. stoljeća. Uključivanjem intelektualaca, redovnika, učitelja, činovnika, trgovaca, obrtnika, zanatlija, radnika $\mathrm{i}$ seljaka u proces nacionalne integracije stvorena je suvremena hrvatska nacija krajem XIX. i početkom XX. stoljeća po uzoru na ostale narode Europe. Mostar je središte procesa integracije hrvatske nacije sve do početka XX. stoljeća kada tu ulogu preuzima Sarajevo. 


\section{The process of Croatian national integration in Mostar}

\section{Summary}

In the second half of the 19th century, Herzegovina experienced major changes when, after Herzegovina-Bosnian insurrection from 1875 to 1878 and the Congress of Berlin, Catholic Austro-Hungarian Monarchy arrived at this region. In the process of Croatian national integration in Bosnia and Herzegovina, during the period of mass national agitation and, partly, a mass national movement, Mostar was the center of such events. The establishment of the Fraternity of St. Anthony of Padua, the opening of a printing house, arrival of the nuns from Maribor and public procession through the city for Corpus Christi marked the beginning of that period. It ended at the beginning of $20^{\text {th }}$ century when the process of national integration included peasants and workers as well and turned into a mass national movement. With the arrival of the Austro-Hungarian Empire, the city became a center of Croatian culture, education and publishing. Newspaper publishing activities among Croats could be linked to Fran Milicevic and Herzegovinian Basil, New Herzegovinian Basil, Voice of a Herzegovinian and Dawn during the period of 25 years (from 1883 to 1908). The establishment of the Fraternity of St. Anthony of Padua, with its significant role in expanding the network of Croatian institutions in Herzeg-Bosnia, marked the process of establishing the institutions that gathered members from different social structures. Croatian Choral Music Society Hrvoje was an example and incentive for other Croatian institutions in Herzeg-Bosnia of how to work for the people's cause. Through its activities Hrvoje became a serious amateur theater that developed love for such kind of art among the citizens. A large number of different Croatian associations worked in Mostar at the end of the $19^{\text {th }}$ and the beginning of the 20th century. By including intellectuals, priests, teachers, clerks, merchants, craftsmen, artisans, workers and peasants in the process of national integration, a modern Croatian nation was created at the end of 19th and the beginning of the 20th century based on the model of other nations of Europe.

Keywords: national agitation, Fraternity of St. Anthony of Padua, printing house, newspapers, HGPD Hrvoje, associations, theater. 